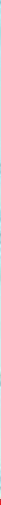

\title{
IntechOpen
}

\section{Customer Relationship Management and IT}

\author{
Edited by Danil Dintsis
}

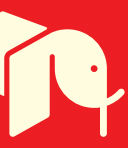





\section{Customer Relationship Management and IT \\ Edited by Danil Dintsis}



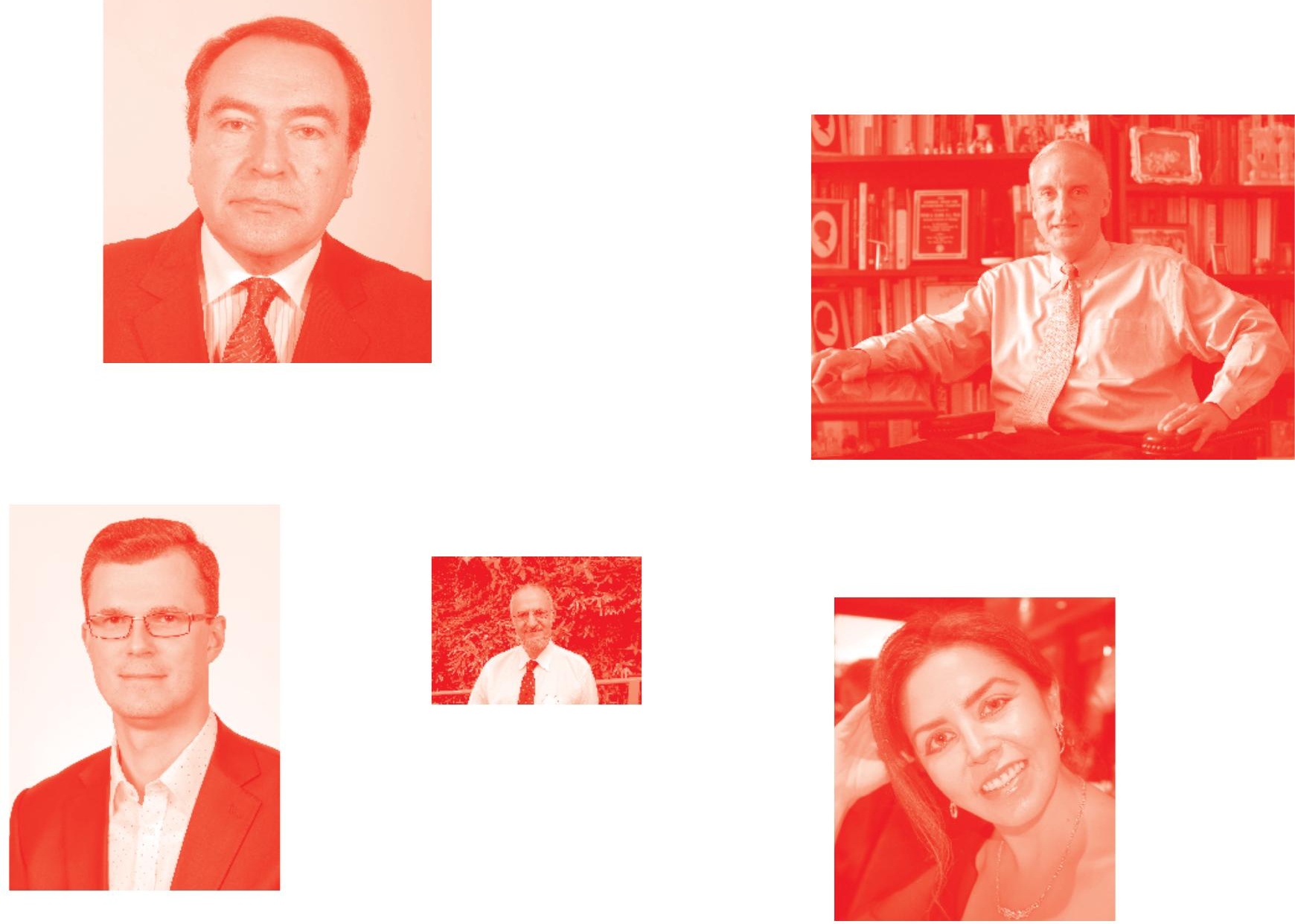

Supporting open minds since 2005
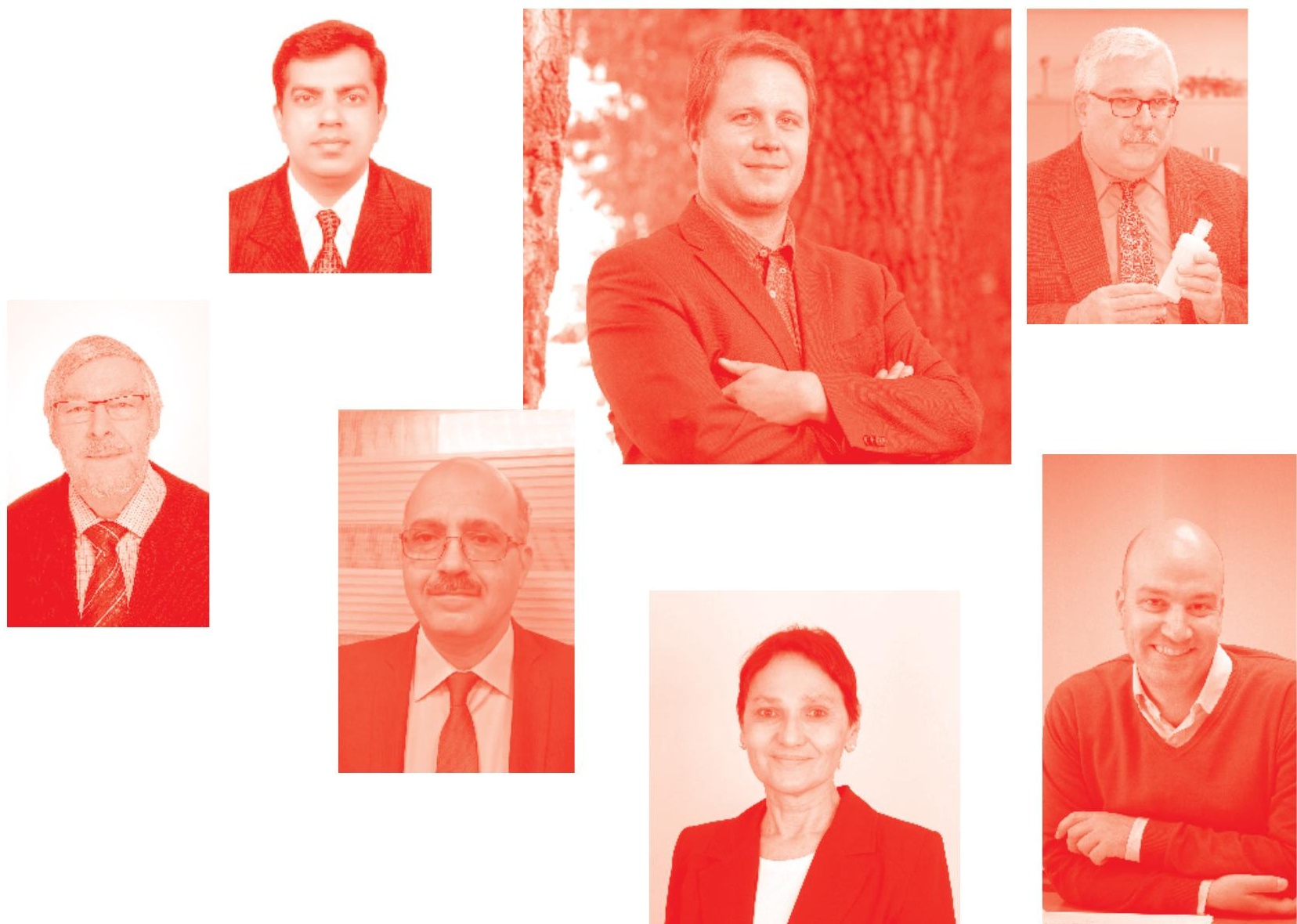
Customer Relationship Management and IT

http : //dx. doi. org/10.5772/intechopen. 77542

Edited by Danil Dintsis

\section{Contributors}

Titus Okeke, Christoph Weiss, Johannes Keckeis, Manfred Kofler, Ahmad Rafiki, Joan Alcúdia Morales, Marina Romeo, Bhanu Prakash Nunna, Danil Dintsis

(-) The Editor(s) and the Author(s) 2020

The rights of the editor(s) and the author(s) have been asserted in accordance with the Copyright, Designs and Patents Act 1988. All rights to the book as a whole are reserved by INTECHOPEN LIMITED . The book as a whole (compilation) cannot be reproduced, distributed or used for commercial or non-commercial purposes without INTECHOPEN LIMITED's written permission. Enquiries concerning the use of the book should be directed to INTECHOPEN LIMITED rights and permissions department (permissions@intechopen.com).

Violations are liable to prosecution under the governing Copyright Law

\section{(cc) BY}

Individual chapters of this publication are distributed under the terms of the Creative Commons Attribution 3.๑ Unported License which permits commercial use, distribution and reproduction of the individual chapters, provided the original author(s) and source publication are appropriately acknowledged. If so indicated, certain images may not be included under the Creative Commons license. In such cases users will need to obtain permission from the license holder to reproduce the material. More details and guidelines concerning content reuse and adaptation can be found at http : //www . intechopen . com/copyright-policy . html .

\section{Notice}

Statements and opinions expressed in the chapters are these of the individual contributors and not necessarily those of the editors or publisher. No responsibility is accepted for the accuracy of information contained in the published chapters. The publisher assumes no responsibility for any damage or injury to persons or property arising out of the use of any materials, instructions, methods or ideas contained in the book.

First published in London, United Kingdom, 2020 by IntechOpen IntechOpen is the global imprint of INTECHOPEN LIMITED, registered in England and Wales, registration number: 11086078 , 7th floor, 10 Lower Thames Street, London,

EC3R 6AF, United Kingdom

Printed in Croatia

British Library Cataloguing-in-Publication Data

A catalogue record for this book is available from the British Library

Additional hard and PDF copies can be obtained from orders@intechopen.com

Customer Relationship Management and IT

Edited by Danil Dintsis

p. cm.

Print ISBN 978-1-83880-319-3

Online ISBN 978-1-83880-320-9

eBook (PDF) ISBN 978-1-83880-912-6 


\section{We are IntechOpen, \\ the world's leading publisher of Open Access books}

Built by scientists, for scientists

\section{$4,800+$ \\ $123,000+$ \\ International authors and editors \\ $140 \mathrm{M}+$ \\ Downloads}

Our authors are among the

151

Countries delivered to

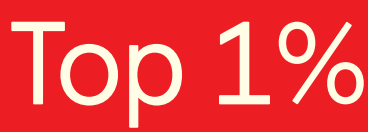

most cited scientists

Contributors from top 500 universities

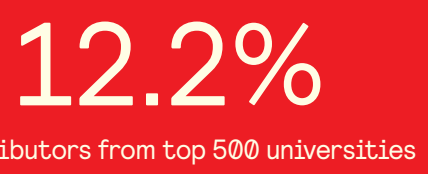

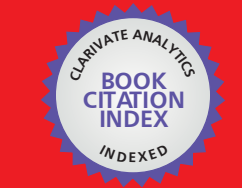

WEB OF SCIENCE ${ }^{\text {M }}$

Selection of our books indexed in the Book Citation Index

in Web of Science ${ }^{\mathrm{TM}}$ Core Collection (BKCI)

\section{Interested in publishing with us? \\ Contact book.department@intechopen.com}

Numbers displayed above are based on latest data collected.

For more information visit www.intechopen.com 



\section{Meet the editor}

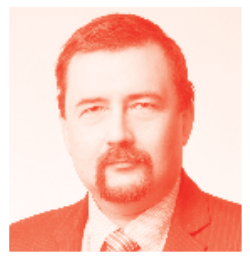

Dr. Danil Dintsis holds a doctorate degree in system analysis, and his total experience in applied digital math and computer science is more than 25 years. He is the leading lecturer in the Specialist Computer Training Center (Moscow), a visiting professor at the Global Business School Barcelona, and an active consultant and startup mentor. Dr. Dintsis is the author of more than 80 publications (including monographs, 5 publications in the IEEE proceedings, and several IntechOpen publications) in the field of computer science. His main area of specialization is fuzzy logic and stochastic graph models. Practical applications of Dr. Dintsis's research are in the area of lifelong learning methods and systems. He holds several prestigious business certifications: PMP ${ }, \mathrm{PgMP} \circledast$, ITIL ${ }^{\text {4 }}$.0 Managing Professional. 



\section{Contents}

Preface

Section 1

Introduction

Chapter 1

Introductory Chapter: Customer Satisfaction Alignment with

"On the Edge" IT Tools

by Danil Dintsis

Section 2

Analyzing Modern CRM Practices

Chapter 2

Customer Relationship Management Practices in Islamic Banks by Ahmad Rafiki

Chapter 3

Customer Satisfaction with Online Retail Transactions

by Titus Okeke

Chapter 4

Qualitative Analysis of Different CRM Evaluation Models

by Christoph Weiss, Johannes Keckeis and Manfred Kofler

Section 3

E-consuming Behavior

Chapter 5

Values and e-Consumer Behavior

by Joan Morales Alcúdia and Marina Romeo Delgado

Chapter 6

A New Paradigm in Customer Relationship Management by Bhanu Prakash Nunna 



\section{Preface}

Customer relationship management (CRM) is the important branch of management both in B2B and B2C segments. For the last 30 to 40 years, CRM IT systems grew together with general IT opportunities, and now they are an essential part of the management landscape in most companies. Big data opportunities and technologies provide a breakthrough in customer relationship management and improve the role of IT in the process. This book provides rich experience in implementing AI, machine learning, and statistical analysis for CRM. The authors analyze CRM practices in retail, online shopping, and in the financial and educational sectors. The chapters contain analytical research and meta-analysis of various customer groups: differentiated by age, region, and income. This book can be valuable for researchers, students, and CRM practitioners.

Danil Dintsis

RU Training Center, Global Business School, Moscow, Russian Federation

Global Business School, Barcelona, Spain 

Section 1

\section{Introduction}





\section{Introductory Chapter: Customer Satisfaction Alignment with "On the Edge" IT Tools}

\section{Danil Dintsis}

\section{Introduction}

This book is about the new role of IT in managing customer relationships. CRM (or customer relationship management) systems are well-known and widely implemented for a long time. On the edge IT technologies provide an opportunity for a breakthrough in customer relationship management and improve the role of IT in the process. In this book the respected authors represent their experience and provide meta-analysis of the IT technologies implementation in the subject area and the results gained.

In the current chapter, the author, who is the academic editor of the book, presents his vision and approach of the role of IT and especially on the edge technologies for customer relationship management.

The growth of the on the edge technologies such as big data [1], machine learning, and artificial intelligence [2] provides new opportunities for customer relationship management. In this chapter, the author makes a general overview of those new opportunities and tools.

I.Implementing artificial neural networks (ANN)

The ANN tools provide support for the vast area of business tasks in CRM area.

a. Define product groups or bundle offers for sales

b. Define customer groups by behavior

c. Search for customer individual preferences

d. Customer recognition technologies:

e. Face recognition to improve customer service

f. Voice recognition

g. Emotion recognition (voice and chat)

II.Graph models. Predict customer path and lifecycle in a company

a. Define probable customer journey (on the example of buying a ticket)

b. Define customer lifecycle in a company 
III.Fuzzy logic models
a. Estimate customer satisfaction
b. Estimate customer demand and develop new products/services/offers
c. Estimate demand
d. Estimate internal capabilities and capacity
e. Estimate external (market/technology) capabilities and capacity
f. Develop a product/service/offer

\section{Applied research and analysis methods}
a. Author analyses his own projects results.
b. Meta-analysis of existing publications and articles.
c. Analysis of request forms and queries.

\section{Implementing of ANN tools}

In this section I deliver our team experience of applying emotion recognition of a customer for call (contact) center systems and leisure services (karaoke and similar). Well-known fact is that customer satisfaction is one of the most important indicators for business. Net present score (NPS) is often used as such indicator based on customer satisfaction surveys. But NPS is a kind of the lagging (or postmortem) indicator. An organization can implement also the so-called leading (or proactive) indicators. For example, contact centers and some other services can use speech emotion recognition services and manage customer satisfaction in a real-time mode.

Detecting customer reaction by emotion recognition is a task, which can be solved using both supervised and unsupervised ANN learning [2, 3]. In this chapter, the author represents the example of the emotion recognition based on voice speed and timbre analysis without speech recognition.

In this model we do not recognize speech, but emotions only. The recognition technique is based on the analysis of the so-called static and dynamic parameters. Static parameters are basic voice timbre: gender (if known). Dynamic parameters are the following: voice timbre change, speech speed and loudness, and surrounding noise level.

Static parameters are basic for a certain caller (or user). They help to adjust the dynamic parameters during the contact session. The ANN contains input layer, which consists of:

- Gender (if known)

- Age (if known)

Input audio are separated into eight components. Each component is equivalent to a certain frequency in the voice audio range: starting from $300 \mathrm{~Hz}$ and to $16 \mathrm{kHz}$. 
- The first hidden layer includes artificial neurons for:

- Basic voice timbre

- Gender (can be empty)

- Age (can be empty)

- Starting surrounding noise level

The second hidden layer proceeds the loudness parameter and contains, for example, artificial neurons for the following attributes:

- Level of surrounding noise loudness

- Level of total voice loudness

- Level of high-frequency loudness

- The third layer proceeds the timbre parameters, and contains the following:

- Differences in timbre

- Trend in timbre differences

The fourth layer proceeds speech tempo parameters, such as:

- Faster

- Slower

- The same

- Trend in speech tempo

The output layer contains the artificial neurons, which indicate user's satisfaction:

- Neutral

- Better

- Worse

- Excited

- Dissatisfied

The simplified example of the ANN is shown in Figure 1.

The training algorithm is based on backpropagation analysis with elements of convolutional artificial neural network [3, 4].

As the result, a contact center agent can receive an advice about customer emotions in a real-time visual mode. This helps an agent to correct his/her talk with a customer and gain customer satisfaction. 


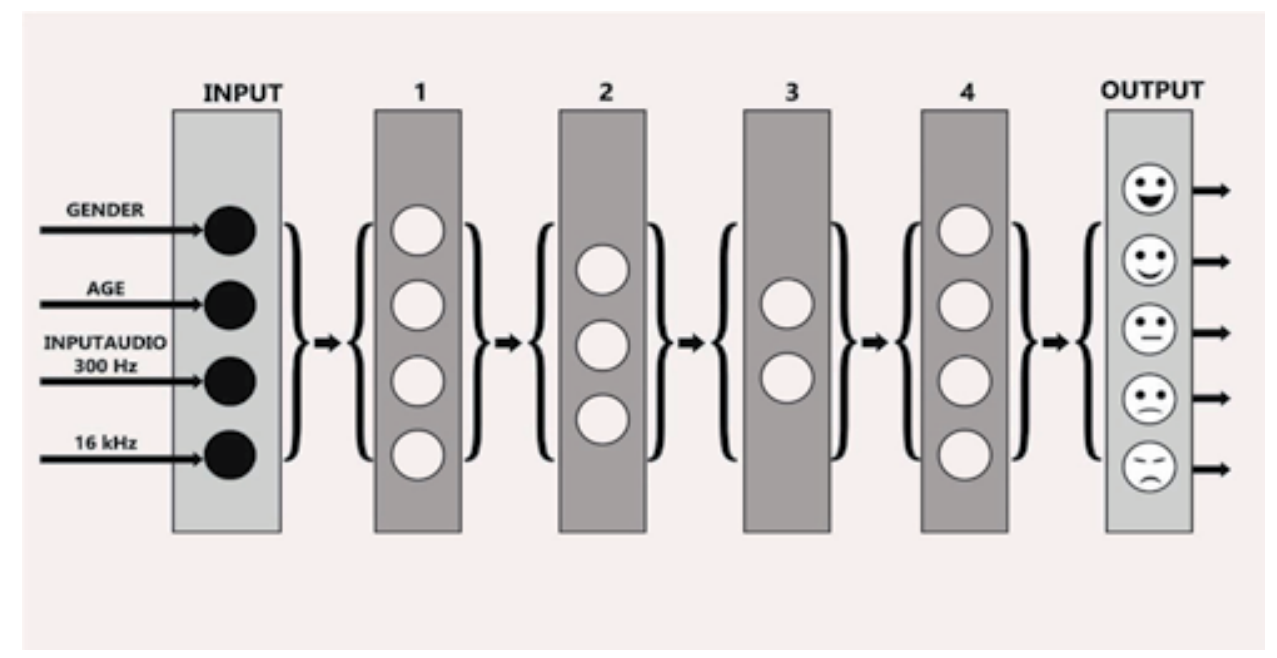

Figure 1.

ANN Schema.

\section{Stochastic graph models for customer lifecycle and behavior prediction}

In this section I deliver the stochastic graph model [5], which controls a userticket buyer-behavior at the ticket-selling Website. The goal of the ticket selling organization is to maximize revenues with minimal expenditures and simultaneously serve as many clients as possible. The ticket system should be able to predict customer behavior at the Website, offer special prices in a dynamic mode, and change number of offered places (e.g., additional carriers in a train or additional flights).

The stochastic graph tools [6] are worth to solve this class of tasks, because user's behavior at a Website is probabilistic at each step. Below we discuss step by step the model of a ticket-buying process.

The stochastic graph nodes indicate current state of a system, and edge reflects an action which leads to a new state. Each edge is weighted with a probability of a certain action- $p(\mathrm{ij}$ ) - where $\mathrm{i}$ is a starting node and $\mathrm{j}$ is a target node (Figure 2).

Usually a node will have a loop, which indicates that a user stays at a current state or leaves the system with a certain probability $\mathrm{p}(\mathrm{i}, \mathrm{i})$ (Figure 3 ).

1. The first node is "Start page open" $\mathrm{V}(1)$.

There are at least three probable next steps by a user (Figure 4):

a. Authorize in the ticket system (V2).

b. Select a route destination (V3).

c. Leave the ticket system (loop) (V1).

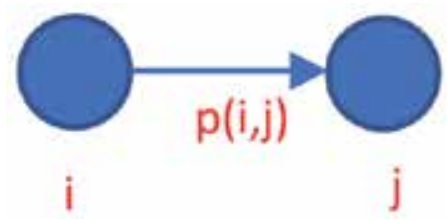

Figure 2.

Simple stochastic graph. 


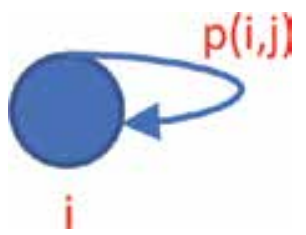

Figure 3.

Stochastic loop.

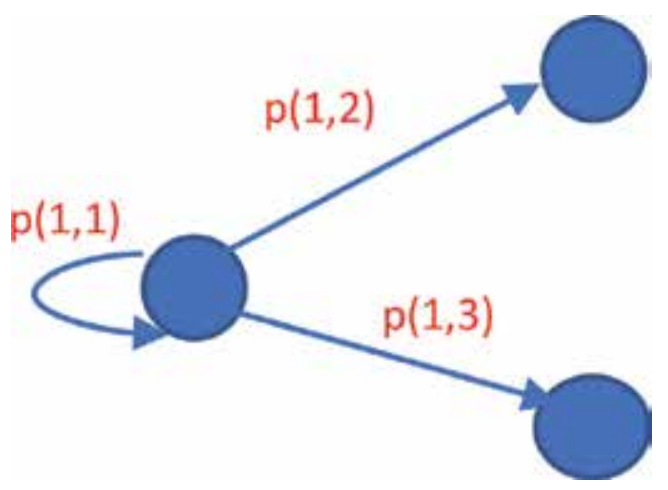

Figure 4 .

Stochastic routes at step 1.

2. If $\mathrm{V} 2$ path is selected, the system makes estimate of the demand based on statistical data. Certain dynamically based tariff is generated for a user

3. If the user authorizes (V3 node), preferred routes and destinations can be offered. Let us examine the probabilities at the next step

4. From V2 node the user can:

a. Select the route, time, and carrier (move to V4 node). Note: each of the mentioned parameters implies on ticket cost. The ticket seller can make changes dynamically, for example:

i. Add or remove carriers.

ii. Increase/decrease costs for certain routes/carrier types/time slots.

b. Move to a new selection page (V5 node).

c. Authorize (move to V3 node).

d. Leave the page (move to V1 node).

5. From the V3 node the user can:

a. Select a route and destination from a preferred list (V6 node).

b. Move to a new selection page (V5 node).

c. Leave to the start page (V1 node). 


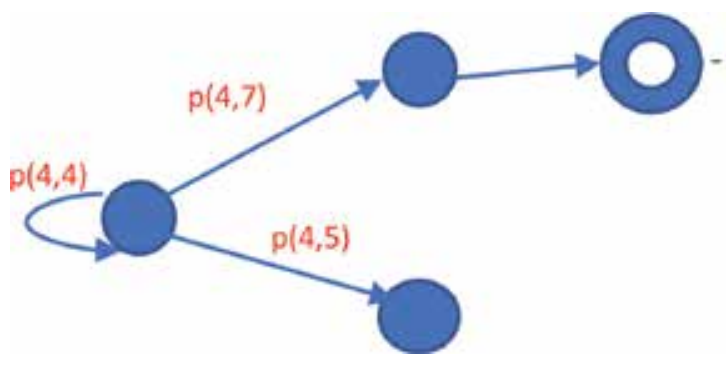

Figure 5.

Stochastic routes at the end of customer journey.

Next, I show the main path on this graph, at which a user moves to buy a ticket procedure.

6. From V4 node a user can select a place (Figure 5). Note: each place has attribute of cost (e.g., more convenient according to general statistical information and more preferred by this certain user). The ticket system can have varying costs in order to gain more revenue from this certain order or by filling the carrier. In the first case the price increases and in the second decreases. See stochastic paths from V4 node in Figure 5.

a. Buy ticket-move to $V(7)$ node.

b. Return to the selection page (V5 node).

As a result, the stochastic graph model can adjust the ticket system behavior according to the user's behavior based not only on previous statistical data but on the probability of his/her behavior in the current session. Those algorithms can improve both customer satisfaction and operator's value.

\section{Role of fuzzy logic in defining and balancing customer demand while creating a new product or a service}

Fuzzy (or linguistic) models usually implement subject matter (or common) terms, for example, "good," "cheap," "far," etc. Fuzzy models, as described by Lotfi Zade and other researchers [7-9], provide formal models based on linguistic terms by simultaneous inclusion of an element into several sets. The author of the article provided a research [10], in which he shows the extended definition area of fuzzy element weight from interval $[0 ; 1]$ to $[-\infty ; \infty]$. The extended definition area provides the opportunity to apply fuzzy logic together with scoring models.

Let us consider a task of developing a new customer offer (either product, goods, or service) based on customer feedback analysis, company capabilities, technological opportunities, and other factors. The author previously published his experience in applying fuzzy logic to develop new service offers for lifelong learning business [10].

Learning organization efficiency on the other hand depends on student's satisfaction and their willingness for continuous learning and capabilities to deliver learning services cheap and adapt them to changes in customer demand.

Based on customers' surveys, and their analysis, the author defined students' professional improvement and satisfaction as one of the critical success factors. The main satisfaction attributes are: 
- Price (mark this attribute with parameter named P)

- Personalized approach (PA)

- Mobility (MB)

- Actual content (AC)

All attributes are represented as fuzzy linguistic variables in L. Zade terms $[0 ; 1]$ with step 0.2 , which is like a common 5 grade model (1-5 grades). Based on those weights (and a lot of others as well), the learning organization developed a series of learning methods combining class-based, online, blended, synchronous, and asynchronous learning. Table 1 is the excerpt from the decision matrix.

In this chapter, the general overview of this approach is given, including new data from the latest projects. The "big data" tools such as ANN, graph models, fuzzy sets, and others can help organizations in building strong customer relationship, based on real-time knowledge about customer demand, happiness, and trends.

In this book, the respected reader learns about concrete implementations of IT tools in CRM systems in different countries and businesses.

\begin{tabular}{lccccc}
\hline Learning method/attributes & Class traditional & Webinar & Blended & Self-paced & Micro-learning \\
\hline Price & 0.2 & 0.4 & 0.2 & 0.6 & 1 \\
\hline Mobility & 0.2 & 0.8 & 0.6 & 0.6 & 0.8 \\
\hline Personal approach & 0.6 & 0.2 & 0.8 & 0.4 & 0 \\
\hline Actual content & 0.8 & 0.6 & 0.4 & 0.4 & 0.6 \\
\hline
\end{tabular}

Table 1.

Awareness level of fuzzy model attributes.

\section{Author details}

Danil Dintsis ${ }^{1,2}$

1 RU Training center, Global Business School, Moscow, Russian Federation

2 Global Business School, Barcelona, Spain

*Address all correspondence to: consult@dintsis.org

\section{IntechOpen}

(C) 2020 The Author(s). Licensee IntechOpen. This chapter is distributed under the terms of the Creative Commons Attribution License (http://creativecommons.org/licenses/ by/3.0), which permits unrestricted use, distribution, and reproduction in any medium, provided the original work is properly cited. (c) BY 


\section{References}

[1] Big Data. Glossary. Gartner group. Available from: https://www.gartner. com/en/information-technology/

glossary/big-data as of January 02, 2020

[2] Ng A. Machine Learning Yearning. 2018. Available from: https://www. deeplearning.ai/machine-learningyearning/

[3] Ng A. Deep learning: From basics to practice. V.1. Seattle: Imaginary Institute; 2018

[4] Ng A. Deep learning: From basics to practice. V.2. Seattle: Imaginary Institute; 2018

[5] Ibe OC. Fundamentals of stochastic networks. O’Reilly Publishing; 2011. ISBN: 9781118092989

[6] Dintsis D, Dedegkayev A. Parallel decomposition of the stochastic model. In: Conference on Information math models, cybernetics and AI.

Moscow - Ryazan. 1999

[7] Zadeh L. The concept of a linguistic variable and its application to approximate reasoning-I. Information Sciences. 1975;8:199-249

[8] Zadeh LA. "Fuzzy sets" archived 2015-08-13 at the Wayback machine. Information and Control. 1965;8(3): 338-353

[9] Dubois D, Prade H. Fuzzy Sets and Systems. New York: Academic Press; 1988

[10] Dintsis D. Implementing fuzzy sets for "big data" analysis based on large training center feedbacks. In: IEEE AEIT Annual 2015 Conference; October, 2015; Naples, Italy 
Section 2

\section{Analyzing Modern CRM Practices}





\title{
Customer Relationship Management Practices in Islamic Banks
}

\author{
Ahmad Rafiki
}

\begin{abstract}
This chapter explores the implementation of customer relationship management (CRM) in Islamic banks through two components of organizational and technological factors. The CRM is one of the solutions to resolve the two common issues that are low level of public awareness toward the Islamic banks' products and low level of Islamic financial literacy. A mix method that is used in this chapter consists of quantitative method using descriptive analysis and qualitative method using content analysis based on a review of literature. A stratified sampling technique is used to collect questionnaires from a total of 22 respondents. The findings reveal that a majority of respondents agreed to all statements related to organizational and technological factors, which affect the CRM implementation. The information in this chapter can be useful, or as a reference, for stakeholders, particularly the financial service authority and the bank of Indonesia in developing the Islamic banks.
\end{abstract}

Keywords: CRM, organizational factor, technological factor, Islamic banks, Indonesia

\section{Introduction}

The borderless business transaction is a challenge in this global competition. There are factors that convince customers to continuously purchase the products. One of them is an excellent service; thus, companies nowadays are improving their services by identifying the customers' preferences and strengthening the relationships with customers, then customers' expectations can be fulfilled and make them satisfy.

Managing personalization of the customer experience has been an important task. The idea of having happy customers through better services is a key motivation in any organizations. Moreover, the increasing of online price-product transparency causes a change in customers' orientations and demands, whereby customers are more meticulous in selecting and comparing the best prices. This is one of the challenges for the Islamic banks to preserve the customer loyalty and obtain the "value for money."

Nowadays, the companies' ways in approaching the customer are changing toward more closer and highly responsible. It is therefore necessary to differentiate the business approaches toward customer and product orientation. As customer orientation is importantly needed to improve customer relationships, companies 
are focusing on factors such as personalization, personal contact/care, and privilege marketing to attract customers' attention. When the managers are able to detect, monitor, and satisfy customer needs and expectations, it displays the importance of CRM [1]. In fact, there are studies that revealed the factors affecting the CRM success (e.g., [2-6]).

Customer relationship management (CRM) is a concept, which consists of strategies, technologies, and practices used to analyze and manage their interactions with the customers. The ultimate goal of CRM is to improve the business relationship while driving sales growth and improving customer retention. The company maintains such relationship by analyzing data and information about the customers and hence can predict future sales and behaviors.

CRM might be used and applied in many companies including the Islamic banks. The Islamic bank is an institution, which is governed by the Islamic law called as shariah. However, this institution requires an understanding on the needs of consumers and establishes reliable relationships with customers; one of the ways is by applying the CRM in its business operations. Islamic banks must create competitive advantages and compete in terms of the uniqueness of products and services with other banks. Therefore, it is important to observe the practices of CRM in the Islamic banks, which can be used as a reference to other banks.

\section{Literature review}

CRM is needed by the company that has high concern on dealing with customers, which considered as a competitive advantage. The main support of CRM is the information technology, which plays a role in maintaining and sustaining CRM [7]. A positive relationship with customers has been attributed to the improved sales volume among different companies [8]. Using CRM, the Islamic banks are able to compete in the industry, where the costs of direct sales can be reduced. However, to get and to collect the information related to the behaviors of consumers are not an easy task. These consumers' databases can be useful for any actions to provide better business operations.

Peppers and Rogers [9] explore the existence of a global tendency to the concept of CRM, regardless of the industry of the business. This is because the companies are concerned on creating the customer satisfactions, increasing the expectations, and achieving the long-term loyalty of the customers.

According to Pradan [10], CRM is increasingly becoming a marketing tool for retail and wholesale businesses. It is meant for long-term growth, which is demanded by multinational corporations. Eventually, CRM is effective in providing strategic concepts through efficiency improvement, customer retention, and market development [11]. The application of CRM is beneficial to the companies including the incidence of innovation, value enhancement, and service improvement. Potentially, company goals regarding the use of CRM are aligned toward creating value for the customers, customization of products, and improving customer profitability [12].

\subsection{CRM definition}

CRM can be reckoned as a business philosophy that allows organizations to comprehend customers' needs and requirements clearly through their histories and preferences, which can be used as the key in helping organizations to plan for the long run. Table 1 elaborates CRM definitions. 


\begin{tabular}{ll}
\hline Author & Definition \\
\hline $\begin{array}{l}\text { Shang and Chen } \\
\text { [13] }\end{array}$ & $\begin{array}{l}\text { A philosophically related offspring to relationship marketing which is for the most } \\
\text { part neglected in the literature. }\end{array}$ \\
\hline Adam et al. [14] & $\begin{array}{l}\text { As an enterprise approach that comprehends and affects customer behavior by } \\
\text { using effective communications in order to improve customer acquisition, client } \\
\text { retention, customer commitment, and customer profitability. }\end{array}$ \\
\hline Ramani and & $\begin{array}{l}\text { Involves all the processes needed to achieve, build, and maintain an ongoing } \\
\text { relationship with customers through differential and tailored treatment of } \\
\text { individual customers based on their likely responses to alternative marketing } \\
\text { programs, so the contribution of each customer to the overall profitability of the } \\
\text { firm is maximized. }\end{array}$ \\
\hline Goldenberg [16] & $\begin{array}{l}\text { As a business approach integrating people, processes and technology in } \\
\text { maximizing relationships with customers. }\end{array}$ \\
\hline Raab et al. [17] & $\begin{array}{l}\text { A management philosophy that is aligned toward existing and potential customer } \\
\text { relationships within a company. }\end{array}$ \\
\hline $\begin{array}{l}\text { Grant \& } \\
\text { Anderson [18] }\end{array}$ & $\begin{array}{l}\text { New avenues for expansion of the organization through improvement of } \\
\text { customers' retention, values, and satisfaction. }\end{array}$ \\
\hline $\begin{array}{l}\text { Schermerhorn } \\
\text { [19] }\end{array}$ & $\begin{array}{l}\text { The concept when in business utilizes the latest technology in maintaining intense } \\
\text { rapport with customers both current and future. }\end{array}$ \\
\hline Nickels [20] & $\begin{array}{l}\text { The concept is a process of understanding customers and working toward } \\
\text { satisfying and exceeding customer expectation through the provision of customer } \\
\text { needs and desires. }\end{array}$ \\
\hline $\begin{array}{l}\text { The concept is important in that it helps the company in anticipating customer } \\
\text { needs and wants and thus building strong customer relationships. }\end{array}$ \\
\hline
\end{tabular}

Table 1.

CRM definition.

\subsection{Islamic banks development}

Islamic banking has positive attention by the international banking system and has become a very fast-growing element of global capital markets in the last 20 years. Islamic banks still take a large portion of $75 \%$ on global Islamic finance total asset. There is a great interest toward Islamic banking not only by those adopted Islamic law but also in the global scale. According to World Islamic Banking Competitiveness Report 2016 of Ernst and Young, ${ }^{1}$ it is estimated that the size of assets of global Islamic banks as of the year 2015 is already over $\$ 1$ trillion, and the growth rate thereof between 2008 and 2012 is $17.6 \%$. Although most of them are in the countries of densely Muslim population, over 300 Islamic banks carry on their activities in more than 75 countries including many Western ones. The largest share of Islamic financial assets in the world belongs to Islamic banking, and the ratio thereof has reached $81 \%$ [21].

Meanwhile, the total assets of Islamic banks in Indonesia reach US\$29.94 billion [22]. Another positive indicator of Islamic banks is the Islamic banking growth in 2017 that reaches $11.10 \%$, which is higher than the total banking system growth of $6.78 \%$ [23]. However, the Islamic banks in Indonesia have a low market share of 5\%, which ironically contrast with the potential as the most Muslim population of 265 million in the world. Among the problems emerged are limited/unvaried product range, low literacy and inclusion level of Islamic finance, unfavorable perception for Islamic banking, lack of talent and qualified employees, limited distribution networks and outreach, and only focus on the retail segment. 
Nalan [21] mentioned that the key principles or features in the Islamic finance system emphasize on the need of sharing the risk, equity, and stakes with the customers. The sharing aspect as the main requirement in the Islamic banking system suggests that the outcome of a project, whether it is profitable or otherwise, will be shared in an equitable manner [24]. The essence of Islamic principles is to achieve a fair distribution of wealth. The main aim of the Islamic banking system is to shield the benefits and interests of all parties who are involved in the economic transaction and to promote the welfare of the whole society as well [25].

\subsection{CRM and shariah compliance}

Islam has shariah law, which brings benefit to all people and avoids the harms. All products and methods in the Islamic banks have to comply with shariah. CRM is a tool or method used to collect the data of consumers, build the relationship, and create the consumers' retention and satisfaction. Islam allows every person to collect data or any information related to the business purposes. The data must be true and genuine that should be used for goodness or not use for speculative actions. Muslims must avoid from cheating and stealing acts.

Build and establish relationship is encouraged in Islam, which is known as ukhuwah Islamiyyah; thus, it is aligned with CRM objectives. With this relationship, consumers and sellers can collaborate and support each other aimed to gain mutual benefits. In CRM, the Islamic banks can widen the network through relationships, which then able to promote the products efficiently, update any features proportionately, and convey the offerings effectively. As CRM aimed for consumer satisfaction, Islam always tries to deliver the excellence services as possible. Satisfaction is qanaah in Islamic term, which means an achievement for every Muslims. Thus, CRM and Islam have similar goals that carry maslahah for the ummah.

\subsection{CRM components}

CRM practices represent opportunities to proactively extend the services to its customers and gain satisfaction and loyalty. Wang and Feng [26] found that CRM capabilities reflected a firm's skill and knowledge in regularly establishing, maintaining, upgrading, and re-establishing beneficial relationships with attractive customers.

Gupte [27] mentioned that CRM tools are implemented to:

i. manage customer communication and enhance visibility of the organization to its customers;

ii. act as a one stop shop for customer interactions, customer information, and accessible databases; and

iii. act as an information management tool, which is practiced to generate, characterize, store, represent, reproduce, and translate the information.

Two main CRM components are widely used in many organizations including in the Islamic financial institutions namely organizational and technological factors. Some organizations have spent tremendous resources on information and computer technologies; however, the organization factor also needed to support and implement the CRM. 


\subsubsection{Organizational factors}

Organizational factors refer to the factors that relate directly or indirectly to the structural, operational, human, and managerial sides of the business entity. Becker et al. [28] stated that the organizational factors such as organizational structure, employee training, employee incentives, and customer orientation are significantly related to CRM performance. Nath et al. [29] posited that a few numbers of dedicated workers contribute to the failure of CRM implementation; therefore, companies must engage the workers with necessary advancement and transformation to accommodate the CRM systems.

Payne and Frow [30] mentioned that the key organizational factors associated with the CRM success consist of company's structure and its operational business procedures. Meanwhile, Croteau and Li [31] added that a suitable organizational arrangement through collaboration of various units and functions in the company is crucial to accomplish CRM missions.

Though there are other dimensions of CRM that could be adopted, the organizational factors still remain considered as the main dimensions based on previous studies [32-50]. There are three organizational factors that will be discussed in this chapter.

\subsubsection{Top management support}

This crucial attention from the executive level is emphasized by Buttle [51]. In Islamic banks, the top management support has shown in their plan to conduct motivation program, which the employees being asked the purpose and dedication in accomplishing their tasks. With a role model by the leaders, the employees are transformed into the good behavior or attitudes. This commitment from the leaders may generate trust, which plays a significant role in building long-term relationships. One of the bodies that always giving its support is a Shariah Advisor Board. This body will monitor and guide the Islamic banks to the ways in implementing the shariah principles. In having an innovation of products and services, this body is expected to encourage its promotions as long as complied with the shariah law.

Below are the impacts of top management support to CRM implementation in an organization:

\begin{tabular}{ll}
\hline Authors & Function/impact of top management support to CRM implementation \\
\hline Adam et al. [14] & $\begin{array}{l}\text { Establishes necessary level of commitment of staff with relevant expertise to } \\
\text { support the needs of CRM. }\end{array}$ \\
\hline $\begin{array}{l}\text { Chen and } \\
\text { Popovich [33] }\end{array}$ & $\begin{array}{l}\text { As an essential element for bringing an innovation online and ensuring delivery of } \\
\text { promised benefits. }\end{array}$ \\
\hline $\begin{array}{l}\text { Mendoza et al. } \\
\text { [52] }\end{array}$ & $\begin{array}{l}\text { Sets the stages in CRM initiatives for leadership, strategic direction, and alignment } \\
\text { of vision and business goals. }\end{array}$ \\
\hline Kim et al. [53] & $\begin{array}{l}\text { It is essential for assisting the improvement of the relationship and for meeting } \\
\text { customers' needs when introducing new technologies with its traditional } \\
\text { business activities. }\end{array}$ \\
& $\begin{array}{l}\text { The key success factor in CRM (customer acquisition, retention, and } \\
\text { expansion). }\end{array}$ \\
\hline Sohrabi et al. [54] & $\begin{array}{l}\text { Is positively related to organizational performance (customer satisfaction, } \\
\text { profitability, customer loyalty, and market share). }\end{array}$ \\
\hline Eid [4] & \begin{tabular}{l} 
Has a minor negative relationship with organizational performance. \\
\hline Kale [55]
\end{tabular} \\
\hline
\end{tabular}


Most of the abovementioned arguments state a positive relationship between top management support of CRM initiatives. The absence of continuous commitment from the top management can result in the failure of the CRM implementations.

\subsubsection{Customer orientation}

Cai [56] posited that customer orientation is defined as "the set of activities, behaviors, and beliefs that place high priority on customers' interests and continuously create superior customer value." The customer orientation can be seen through the existence of social media that can be used to build sustainable relationships. The client-oriented companies have an emphasis and more attention to personal workers' initiatives, which generate unique values for customers. Those companies recognized the importance of client data handling activities and practices, which used to attain higher CRM performance.

\begin{tabular}{ll}
\hline Authors & Function/impact of customer orientation to CRM implementation \\
\hline Kim [5] & $\begin{array}{l}\text { The weakness in applying and developing customer orientation is the major } \\
\text { reason of inefficient CRM. }\end{array}$ \\
\hline $\begin{array}{l}\text { Day and Van den } \\
\text { Bulte [57] }\end{array}$ & $\begin{array}{l}\text { Has a critical connection to relative sales, benefit, social favorable position, and } \\
\text { retaining client performance. }\end{array}$ \\
\hline McNally [58] & $\begin{array}{l}\text { Customer orientation imperative element for CRM achievement is related to } \\
\text { marketing and information technology, which encourages to create customer } \\
\text { loyalty and other positive impacts to organizational performance. }\end{array}$ \\
\hline
\end{tabular}

Various studies on customer orientation were used as the potential precursors of CRM achievement, e.g., Eid [4], Faed et al. [59], Kim [5], Becker et al. [28], and Sohrabi et al. [54].

\subsubsection{Training orientation}

An adequate training is importantly required in the CRM processes to gain success [13]. The employee's engagement in a training contributes to the advancement of knowledge by accommodating the employees in seeking, disseminating, and using the information to respond the customers' problems and inquiries. Employees who serve the customers closely must be trained. Kim [5] added that the training of employees improves features of the quality creation such as accomplishment of administration excellence, communicating with customized correspondence between the firm and its customers, and also could be used as a benchmark for attitude and behavior.

Training is a requirement to contribute for better outcomes. In Islam, it relates to purifying one's soul (tazkiyah al-nafs), embedding Islamic values (at-ta'dib), understanding the philosophies of Allah's Oneness and Greatness (at-tawheed aluluhiyyah and ar-rububiyyah), the concepts of working as a representative (khalifah), a team (jemaah), full submission to Allah (ibadah), and a way to succeed (al-falah). Thus, in order to implement CRM successfully, the Islamic banks need to invest in training and development of employees' skills.

\begin{tabular}{ll}
\hline Authors & Function/impact of training orientation to CRM implementation \\
\hline $\begin{array}{l}\text { Payne and Frow } \\
{[30]}\end{array}$ & $\begin{array}{l}\text { It is impossible for an organization to develop and operate suitable customer- } \\
\text { focused systems and processes if they lack trained employees. }\end{array}$ \\
\hline
\end{tabular}




\begin{tabular}{ll}
\hline Authors & Function/impact of training orientation to CRM implementation \\
\hline Rigby et al. [60] & $\begin{array}{l}\text { Training of employees is a key in implementation process encompassing customer } \\
\text { service, improving efficiencies, nurturing consumer confidence, and repeating } \\
\text { purchase. }\end{array}$ \\
\hline Kim [5] & $\begin{array}{l}\text { Improves CRM performance and achieves CRM goals of high customer satisfaction } \\
\text { and profitability. }\end{array}$ \\
\hline Eid [4] & $\begin{array}{l}\text { Employee training has a significant positive impact on CRM success in the light of } \\
\text { customer retention. }\end{array}$ \\
\hline $\begin{array}{l}\text { Plakoyiannaki } \\
\text { et al. [61] }\end{array}$ & CRM practice failure is due to the lack of full attention for the role of workers. \\
\hline
\end{tabular}

A well-trained employee has the ability to create a good customer relationship by delivering high-quality products and services. Numerous studies stated that employee training is a key driver, which brings tangible and intangible advantages in CRM implementation [28,62-67]. All of them gave positive proof to the role of employee training to the CRM activities.

\subsubsection{Technological factors}

Zablah et al. [68] posited that the information technology and communication (ICT) are utilized as the instruments for communicating throughout organization, knowledge management, and strategies. The Islamic banks must adopt the ICT as an important element to implement CRM. Technological factors refer to the factors that relate to the soft and hard aspects including ICT infrastructure, system evaluation, and selection criteria; vendor after sale support; software selection criteria; complexity; and integration [2].

Liu [69] stated that there is a necessity to provide the compatible technology and tools to the company due to the significance on establishment of customer strategy. However, some managers are not updated with the latest technology and fail to choose the most suitable package to fit their customer strategy. Kim et al. [12] warned that the success of the CRM depends on how well the information technology (IT) is implemented.

Several researches are confirming the relationship between technology factors and CRM performance such as Lucchetti and Sterlacchini [45], Siegele [70], Cavalcanti [71], Ndubisi and Jantan [72], Utomo [73], and Buonanno et al. [74]. The components of technological factor are customer data, customer information processing, and integration of CRM.

\subsubsection{Customer data}

Islamic banks have to collect customer data, which can be analyzed to come out with a right decision. With a complete data, the marketing or sales staff can execute the plan of approaching customers and maintain a relationship. Islamic banks can collaborate with other bodies formally and informally to get primary or secondary data that can be used for future actions. The danger of dirty, inaccurate, old data for the companies, which include the erroneous numbers, mistakes in spelling, and old contact information that has a high probability of infecting the system, must be avoided. This will also incur huge costs to adjust any damages. 


\begin{tabular}{|c|c|}
\hline Authors & Function/Impact of Customer Data to CRM Implementation \\
\hline $\begin{array}{l}\text { Nelson and } \\
\text { Kirkby [75] }\end{array}$ & $\begin{array}{l}\text { A top cause of failure of CRM initiatives is the poor-quality customer data and } \\
\text { information. This may result in poor data analysis followed by poor decision } \\
\text { making. }\end{array}$ \\
\hline $\begin{array}{l}\text { Ryals and Payne } \\
{[76]}\end{array}$ & Lack of data quality and quantity to be a barrier to successful CRM initiatives. \\
\hline Kim et al. [53] & Better quality of data can improve the confidence of the employees in CRM. \\
\hline Peikin [77] & Data quality occasionally does not strongly support the CRM success. \\
\hline $\begin{array}{l}\text { Bose and Chong } \\
{[78]}\end{array}$ & $\begin{array}{l}\text { - The unfortunate problem of "bad data" hinders the growth of CRM } \\
\text { - Most effective and efficient CRM strategies need good quality data. }\end{array}$ \\
\hline $\begin{array}{l}\text { Jaychandran } \\
\text { et al. [79] }\end{array}$ & $\begin{array}{l}\text { Can support the front-office or customer interaction solutions, which in turn, will } \\
\text { help integrate and analyze the data. }\end{array}$ \\
\hline
\end{tabular}

Many researchers as mentioned above provide evidence of the importance of data analysis and quality for CRM initiatives. A basic factor for successful CRM is an efficient link of customer data to fulfill the customer expectations. The companies are overwhelmed with information, and CRM ultimately focuses on effectively turning information into intelligent business knowledge to administer customer relationships.

\subsubsection{Customer information processing (CIP)}

Customer information processing is defined as relational information processing, which encompasses particular routines used by the organization to set up customer long-term relations [79]. It is also as a component that makes a clear picture of customer and market behaviors, which leads to suitable business actions required in the constantly unstable market environments [80].

Kim [5] stated that the effective CIP has become an emerging challenge for the firms due to the Internet and database technology's potential to assist the collection of comprehensive information on customers' needs, preferences, and behaviors. Kim also added the construct of CIP that consists of one activity after another such as acquisition/generation, analysis, interpretation, and storage of customer information. Moreover, the CIP is crucial for the Islamic banks because it has to deal with the constantly changing of products' offerings as well as the increasingly knowledgeable customers.

\begin{tabular}{ll}
\hline Authors & Function/impact of customer information processing to CRM implementation \\
\hline $\begin{array}{l}\text { Becker et al. } \\
{[28]}\end{array}$ & $\begin{array}{l}\text { Has a significant positive link between the activities related to the collection, storage, } \\
\text { and access to customer information and CRM performance. }\end{array}$ \\
\hline $\begin{array}{l}\text { Kim et al. } \\
{[53]}\end{array}$ & $\begin{array}{l}\text { Managing and using customer information in the marketing efforts will have a strong } \\
\text { impact on their CRM performance improvement. }\end{array}$ \\
\hline Kim [5] & $\begin{array}{l}\text { Can be assisted in identifying their most significant customers to increase their business } \\
\text { value. }\end{array}$ \\
\hline
\end{tabular}

Based on the arguments above, it could be concluded that empirical evidence has shown a positive influence of customer information processing on the CRM initiatives. 


\subsubsection{Integration of $C R M$}

Cross-functional integration emerges as key aspects for CRM success [81]. In both operational and customer-handling systems, various types of integrations are importantly required such as system compatibility, multi-channel integration, functional integration, and data integration [30,63]. There are two factors of system integration that are crucial to CRM: (i) the connection into legacy systems and organizational applications and (ii) throughout other functional customer information [30, 51].

In the Islamic banks, this system integration has a significant and positive influence on both operational and strategic benefits in the organizations, particularly for customer retention. Wang and Feng [26] posited that a number of researchers have shown the importance of system integration as a key success component of a successful CRM system.

\begin{tabular}{ll}
\hline Authors & Function/impact of integration of CRM to CRM implementation \\
\hline Roh et al. [80] & $\begin{array}{l}\text { The integration of CRM system with legacy MIS system positively influences customer } \\
\text { satisfaction and efficiency. }\end{array}$ \\
\hline Capacity [63] & The integration helps to forecast the future trend of CRM. \\
\hline
\end{tabular}

Based on the past studies, the proposed framework of CRM in Islamic Banks is shown in Figure 1.

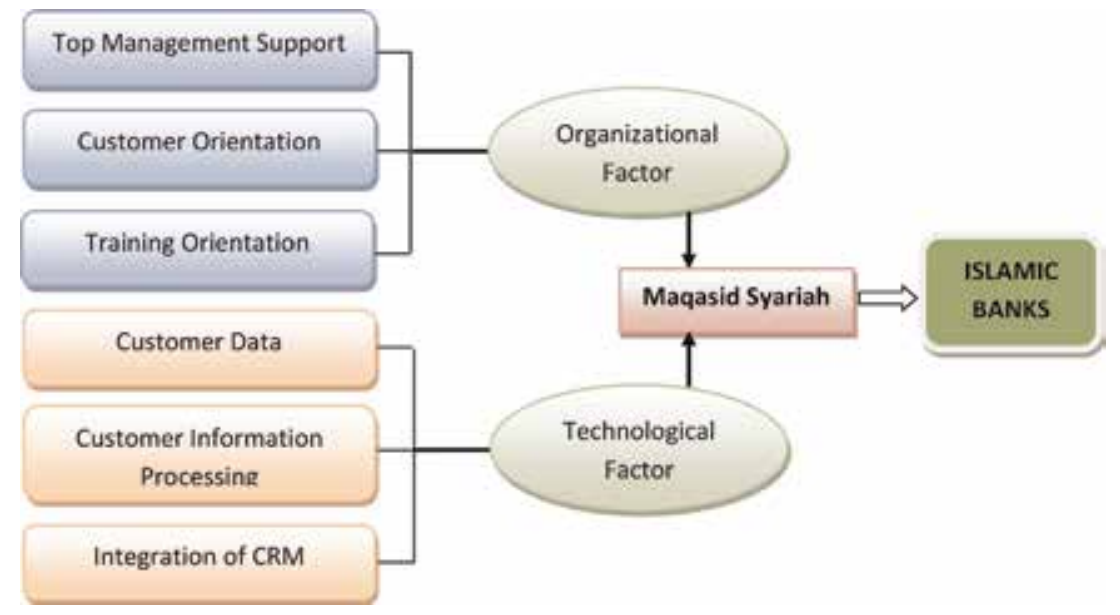

Figure 1.

CRM in Islamic banks (Author's proposed framework).

\section{Methodology}

This chapter conducts a mix method of quantitative method using descriptive analysis and qualitative method using content analysis based on a review of literature from academic research journals, websites, social media platforms, electronic databases (secondary data), and other relevant sources. 
A descriptive analysis is conducted using a survey by distributing questionnaires to support the arguments and elaboration on the CRM practices in Islamic Banks. In this survey, the respondents are the employees from two Islamic banks in Indonesia (PT. Bank Mandiri Syariah and PT. Bank BNI Syariah), which located in Medan City of North Sumatera province. A stratified sampling method is used to collect a total of 22 employees chosen are whom in charge and associated with customer services, sales and marketing, and information technology.

\section{Discussion}

There are two parts of questions related to organizational and technological factors of CRM that are responded by the respondents:

Below are the responses of respondents on each statement in Table 2.

1. $45 \%$ of respondents agree that top management frequently discusses CRM with the staff involved, while $19 \%$ of them disagree with the statement.

2. $40.9 \%$ of respondents agree that CRM is regarded as a high priority by top management. While $13.6 \%$ of them disagree with the statement.

3.22.7\% of respondents agree that top management perceives CRM to be part of the organization's vision, while $13.6 \%$ of them disagree with the statement.

$4.40 .9 \%$ of respondents agree that top management motivates the employees to achieve the CRM objectives, while none of the respondents disagree with the statement.

$5.45 .5 \%$ of respondents agree that top management is involved to a great degree in CRM implementation, while $18.2 \%$ of them disagree with the statement.

6. $45.5 \%$ of respondents agree that they strive to improve the value, which provided to customers, while $4.5 \%$ of them disagree with the statement.

$7.28 \%$ of respondents agree that customer satisfaction is an important business objective, while $10 \%$ of them disagree with the statement.

8.27.3\% of respondents agree that they attempt to understand customer needs, while $13.6 \%$ of them disagree with the statement.

9.13.6\% of respondents both agree and disagree, respectively, that they pay close attention to customer service.

$10.59 .1 \%$ of respondents agree that retaining customers is considered to be a top priority, while none of them disagree with the statement.

11.36.3\% of respondents agree that the employees are encouraged to focus on customer relationships, while $22.7 \%$ of them disagree with the statement.

12.68.2\% of respondents agree that the training facilitates employee's learning of effective ways to address customer complaints, while $13.6 \%$ of them disagree with the statement. 
Customer Relationship Management Practices in Islamic Banks

DOI: http://dx.doi.org/10.5772/intechopen.89225

\begin{tabular}{|c|c|c|c|c|c|}
\hline \multirow{2}{*}{$\begin{array}{l}\text { Statements of organizational } \\
\text { factor }\end{array}$} & \multicolumn{5}{|c|}{ Scale } \\
\hline & $\begin{array}{l}\text { Strongly } \\
\text { agree }\end{array}$ & Agree & Neutral & Disagree & $\begin{array}{l}\text { Strongly } \\
\text { disagree }\end{array}$ \\
\hline \multicolumn{6}{|l|}{ Top management measures } \\
\hline \multicolumn{6}{|c|}{ 1. Top management frequently discusses CRM with the staff involved } \\
\hline Frequency & 4 & 6 & 8 & 3 & 1 \\
\hline Percentage (\%) & 18 & 27 & 36 & 14 & 5 \\
\hline \multicolumn{6}{|c|}{ 2. CRM is regarded as a high priority by top management } \\
\hline Frequency & 3 & 6 & 10 & 3 & 0 \\
\hline Percentage (\%) & 13.6 & 27.3 & 45.5 & 13.6 & 0.00 \\
\hline \multicolumn{6}{|c|}{ 3. Our top management perceives CRM to be part of the organization's vision } \\
\hline Frequency & 1 & 4 & 14 & 2 & 1 \\
\hline Percentage (\%) & 4.5 & 18.2 & 63.6 & 9.1 & 4.5 \\
\hline \multicolumn{6}{|c|}{ 4. Top management motivates the employees to achieve the CRM objectives } \\
\hline Frequency & 3 & 6 & 13 & 0 & 0 \\
\hline Percentage (\%) & 13.6 & 27.3 & 59.1 & 0.0 & 0.0 \\
\hline \multicolumn{6}{|c|}{ 5. Top management is involved to a great degree in CRM implementation } \\
\hline Frequency & 2 & 8 & 8 & 2 & 2 \\
\hline Percentage (\%) & 9.1 & 36.4 & 36.4 & 9.1 & 9.1 \\
\hline \multicolumn{6}{|l|}{ Customer orientation measures } \\
\hline \multicolumn{6}{|c|}{ 6. We strive to improve the value we provide to our customers } \\
\hline Frequency & 6 & 4 & 11 & 1 & 0 \\
\hline Percentage (\%) & 27.3 & 18.2 & 50.0 & 4.5 & 0.0 \\
\hline \multicolumn{6}{|c|}{ 7. Customer satisfaction is an important business objective } \\
\hline Frequency & 3 & 3 & 14 & 1 & 1 \\
\hline Percentage (\%) & 14 & 14 & 64 & 5 & 5 \\
\hline \multicolumn{6}{|c|}{ 8. We attempt to understand customer needs } \\
\hline Frequency & 0 & 6 & 13 & 3 & 0 \\
\hline Percentage (\%) & 0.0 & 27.3 & 59.1 & 13.6 & 0.0 \\
\hline \multicolumn{6}{|c|}{ 9. We pay close attention to customer service } \\
\hline Frequency & 2 & 1 & 16 & 1 & 2 \\
\hline Percentage (\%) & 9.1 & 4.5 & 72.7 & 4.5 & 9.1 \\
\hline
\end{tabular}

10. In our company, retaining customers is considered to be a top priority

\begin{tabular}{lccccc}
\hline Frequency & 7 & 6 & 9 & 0 & 0 \\
\hline Percentage (\%) & 31.8 & 27.3 & 40.9 & 0 & 0
\end{tabular}

11. Our employees are encouraged to focus on customer relationships

\begin{tabular}{lccccc}
\hline Frequency & 3 & 5 & 9 & 4 & 1 \\
\hline Percentage (\%) & 13.6 & 22.7 & 40.9 & 18.2 & 4.5 \\
\hline
\end{tabular}

\section{Training orientation measures}

12. Our training facilitates employee's learning of effective ways to address customer complaints

$\begin{array}{llllll}\text { Frequency } & 6 & 9 & 4 & 2 & 1\end{array}$




\begin{tabular}{lccccc}
\hline \multirow{2}{*}{$\begin{array}{l}\text { Statements of organizational } \\
\text { factor }\end{array}$} & \multicolumn{5}{c}{ Scale } \\
\cline { 2 - 5 } & $\begin{array}{c}\text { Strongly } \\
\text { agree }\end{array}$ & Agree & Neutral & Disagree & $\begin{array}{c}\text { Strongly } \\
\text { disagree }\end{array}$ \\
\hline Percentage (\%) & 27.3 & 40.9 & 18.2 & 9.1 & 4.5 \\
\hline 13. Our training helps employees understand customer needs & & & \\
\hline Frequency & 1 & 5 & 11 & 5 & 0 \\
\hline Percentage (\%) & 4.5 & 22.7 & 50.0 & 22.7 & 0.0 \\
\hline 14. Our training facilitates interpersonal skill training to build customer relationships & \\
\hline Frequency & 3 & 7 & 10 & 1 & 1 \\
\hline Percentage (\%) & 13.6 & 31.8 & 45.5 & 4.5 & 4.5 \\
\hline 15. Our training helps improve employee's team building skills to enhance company operations \\
\hline Frequency & 1 & 6 & 8 & 6 & 1 \\
\hline Percentage (\%) & 4.5 & 27.3 & 36.4 & 27.3 & 4.5 \\
\hline 16. Our training facilitates learning to promote the quality of our products/services & \\
\hline Frequency & 4 & 6 & 5 & 4 & 3 \\
\hline Percentage (\%) & 18.2 & 27.3 & 22.7 & 18.2 & 13.6 \\
\hline
\end{tabular}

Table 2.

Statements on organizational factor.

13.27.2\% of respondents agree that training helps employees understand customer needs, while $22.7 \%$ of them disagree with the statement.

14. $45.4 \%$ of respondents agree that training facilitates interpersonal skill training to build customer relationships, while $9 \%$ of them disagree with the statement.

15.31.8\% of respondents both agree and disagree, respectively, that training helps improve employee's team building skills to enhance company operations.

16. $45.5 \%$ of respondents agree that training facilitates learning to promote the quality of our products/services, while $31.8 \%$ of them disagree with the statement.

Based on the statements from the organizational factor above, all 16 statements concluded that the Islamic banks are concerned on the CRM implementation. It is noted that there are two statements: nos. 9 and 15 where the respondents either agree and disagree, meaning that the Islamic banks were not focus on customer service and training, which help to improve employee's team skills that importantly support the CRM initiatives:

Below are the responses of respondents on each statement in Table 3.

$1.36 .4 \%$ of respondents agree that the cost of acquiring data within our company is reasonable, while $9.1 \%$ of them disagree with the statement.

2.36.3\% of respondents agree that data (error rates, defect rates, scrap, defects, etc.) are easily available when needed, while $22.7 \%$ of them disagree with the statement. 
Customer Relationship Management Practices in Islamic Banks

DOI: http://dx.doi.org/10.5772/intechopen.89225

\begin{tabular}{|c|c|c|c|c|c|}
\hline \multirow{2}{*}{$\begin{array}{l}\text { Statements of technological } \\
\text { factor }\end{array}$} & \multicolumn{5}{|c|}{ Scale } \\
\hline & $\begin{array}{l}\text { Strongly } \\
\text { agree }\end{array}$ & Agree & Neutral & Disagree & $\begin{array}{l}\text { Strongly } \\
\text { disagree }\end{array}$ \\
\hline \multicolumn{6}{|l|}{ Customer data measures } \\
\hline \multicolumn{6}{|c|}{ 1. The cost of acquiring data within our company is reasonable } \\
\hline Frequency & 2 & 6 & 12 & 2 & 0 \\
\hline Percentage (\%) & 9.1 & 27.3 & 54.5 & 9.1 & 0 \\
\hline \multicolumn{6}{|c|}{ 2. Data (error rates, defect rates, scrap, defects, etc.) are easily available when needed } \\
\hline Frequency & 3 & 5 & 9 & 4 & 1 \\
\hline Percentage (\%) & 13.6 & 22.7 & 40.9 & 18.2 & 4.5 \\
\hline \multicolumn{6}{|c|}{ 3. We can get access to the quality data on time } \\
\hline Frequency & 1 & 3 & 16 & 1 & 1 \\
\hline Percentage (\%) & 4.5 & 13.6 & 72.7 & 4.5 & 4.5 \\
\hline \multicolumn{6}{|c|}{ 4. Quality data are available to employees, managers, and supervisors up to a great extent } \\
\hline Frequency & 3 & 3 & 13 & 3 & 0 \\
\hline Percentage (\%) & 13.6 & 13.6 & 59.1 & 13.6 & 0 \\
\hline \multicolumn{6}{|c|}{ 5. Quality data, control charts, etc. are displayed on employee's workstations up to a great extent } \\
\hline Frequency & 5 & 8 & 4 & 3 & 2 \\
\hline Percentage (\%) & 22.7 & 36.4 & 18.2 & 13.6 & 9.1 \\
\hline \multicolumn{6}{|c|}{ Customer Information Processing Measures } \\
\hline \multicolumn{6}{|c|}{ 6. We gather customer-related data } \\
\hline Frequency & 4 & 4 & 8 & 4 & 2 \\
\hline Percentage (\%) & 18.2 & 18.2 & 36.4 & 18.2 & 9.1 \\
\hline \multicolumn{6}{|c|}{ 7. We maintain a customer database } \\
\hline Frequency & 3 & 6 & 7 & 3 & 3 \\
\hline Percentage (\%) & 13.6 & 27.3 & 31.8 & 13.6 & 13.6 \\
\hline \multicolumn{6}{|c|}{ 8. We store data extracted from operational data } \\
\hline Frequency & 4 & 6 & 9 & 2 & 1 \\
\hline Percentage $(\%)$ & 18.2 & 27.3 & 40.9 & 9.1 & 4.5 \\
\hline \multicolumn{6}{|c|}{ 9. We use customer database information to develop attractive offerings } \\
\hline Frequency & 2 & 4 & 13 & 0 & 3 \\
\hline Percentage (\%) & 9.1 & 18.2 & 59.1 & 0 & 13.6 \\
\hline \multicolumn{6}{|c|}{ 10. We offer a loyalty program to reward repeat customers } \\
\hline Frequency & 0 & 5 & 14 & 2 & 1 \\
\hline Percentage (\%) & 0 & 22.7 & 63.6 & 9.1 & 4.5 \\
\hline
\end{tabular}

\section{Integration of CRM Measures}

11. We provide our sales force with adequate customer information

\begin{tabular}{lccccc}
\hline Frequency & 5 & 5 & 10 & 1 & 1 \\
\hline Percentage (\%) & 22.7 & 22.7 & 45.5 & 4.5 & 4.5 \\
\hline
\end{tabular}

12. We provide customized offers to sales people in the field 


\begin{tabular}{|c|c|c|c|c|c|}
\hline \multirow{2}{*}{$\begin{array}{l}\text { Statements of technological } \\
\text { factor }\end{array}$} & \multicolumn{5}{|c|}{ Scale } \\
\hline & $\begin{array}{l}\text { Strongly } \\
\text { agree }\end{array}$ & Agree & Neutral & Disagree & $\begin{array}{l}\text { Strongly } \\
\text { disagree }\end{array}$ \\
\hline Percentage (\%) & 13.6 & 31.8 & 36.4 & 9.1 & 9.1 \\
\hline \multicolumn{6}{|c|}{ 13. We control sales through multiple sales channels } \\
\hline Frequency & 5 & 8 & 3 & 0 & 6 \\
\hline Percentage (\%) & 22.7 & 36.4 & 13.6 & 0 & 27.3 \\
\hline \multicolumn{6}{|c|}{ 14. We assist the marketing department in generating customized offers } \\
\hline Frequency & 4 & 14 & 3 & 1 & 0 \\
\hline Percentage (\%) & 18.2 & 63.6 & 13.6 & 4.5 & 0 \\
\hline \multicolumn{6}{|c|}{$\begin{array}{l}\text { 15. We allow customer support personnel to access data on customer interactions with all functiona } \\
\text { areas }\end{array}$} \\
\hline Frequency & 4 & 9 & 3 & 4 & 2 \\
\hline Percentage (\%) & 18.2 & 40.9 & 13.6 & 18.2 & 9.1 \\
\hline
\end{tabular}

Table 3.

Statements on technological factor.

3.18.1\% of respondents agree that they can get access to the quality data on time, while $9 \%$ of them disagree with the statement.

4.27.2\% of respondents both agree that quality data are available to employees, managers, and supervisors up to a great extent, while $13.6 \%$ of them disagree with the statement.

5.59.1\% of respondents agree that quality data, control charts, and so on are displayed on employee's workstations up to a great extent, while $22.3 \%$ of them disagree with the statement.

6.36.4\% of respondents agree that they gather customer-related data, while $27.3 \%$ of them disagree with the statement.

7. $40.9 \%$ of respondents agree that they maintain a customer database, while $27.2 \%$ of them disagree with the statement.

8. $45.5 \%$ of respondents agree that they store data extracted from operational data, while $13.6 \%$ of them disagree with the statement.

9.27.3\% of respondents agree that they use customer database information to develop attractive offerings, while $13.6 \%$ of them disagree with the statement.

$10.22 .7 \%$ of respondents agree that they offer a loyalty program to reward repeat customers, while $13.6 \%$ of them disagree with the statement.

11. $45.4 \%$ of respondents agree that they provide our sales force with adequate customer information, while $9 \%$ of them disagree with the statement.

12.45.4\% of respondents agree that they provide customized offers to sales people in the field, while $18.2 \%$ of them disagree with the statement. 
13.59.1\% of respondents agree that they control sales through multiple sales channels, while $27.3 \%$ of them disagree with the statement.

$14.71 .8 \%$ of respondents agree that they assist the marketing department in generating customized offers, while $4.5 \%$ of them disagree with the statement.

15.59.1\% of respondents agree that they allow customer support personnel to access data on customer interactions with all functional areas, while $27.3 \%$ of them disagree with the statement.

Based on the statements from the technological factor above, all 15 statements concluded that the Islamic banks are concerned on the CRM implementation.

Among the biggest Islamic banks in Indonesia where all their headquarters are located in Jakarta, CRM initiatives have been adopted just few years ago. This is a concern and a need to improve the development of Islamic banks. The CRM is useful to overcome several issues, for example, the low level of public awareness toward the Islamic banks' products and the low level of Islamic financial literacy, which caused low penetration of Islamic finance that only reached $11.6 \%$. As many of the personnel do not practice effective CRM, some of the Islamic banks thus still engage in training of CRM's familiarization particularly on its systems' applications and technical functions.

In terms of organizational aspect, the top management support is importantly required to implement CRM in Islamic banks especially when the CRM practices involved many departments such as customer services, human resources, information technology, finance/accounting, marketing, production/operation, and multi job tasks. With one commitment from the top management, all the subsidiaries have to obey the instruction of them. From the five questions related to top management support revealed that majority of respondents agreed on its role in CRM implementation. Similarly with the two components of organizational factors (customer orientation and training orientation), a majority of respondents agreed on the imperative influence to CRM practices. Meanwhile, some of the Islamic banks did not have the right structures for recording and updating the customer information. Thus, they have difficulties to create customer satisfaction and loyalty.

The adoption of CRM creates more satisfied and loyal customers, thereby resulting in better organizational effects in both the short and long terms [33, 82], among others by the use of loyalty programs and direct mailings as has been suggested by Verhoef [83]. Most Islamic banks have developed relationship management programs to aid in the enhancement of customer relationships. Keramati et al. [84] asserted that a collaboration of people and technology in an organization is effective in the attainment of holistic approaches to CRM models.

Moreover, on the technological aspect, the customer data play a crucial role because it is a main source that must be right, reliable, and valid, otherwise the use of CRM is ineffective. If a requirement of having a good data is fulfilled, then the findings or results on data analysis can be useful to make right decision. Based on the five questions on customer data indicate that a majority of respondents agreed on the significant impact of customer data to CRM implementation. Similarly for the two components of technological factors (customer information processing and integration of CRM), a majority of respondents agreed on both vital effects toward the CRM practices.

The Islamic banks have to upgrade the database system of CRM. The details of the customers including their names, phone links, and other communication data are captured in the database. In addition, for every transaction including deposits and withdrawals, the details of the customers must be updated. Most of the Islamic 
banks should have automated processes, where details of the customers are automatically captured in the relevant fields for every successive transaction. Moreover, data retrieval for the different customers is a click away, and customers' details can be traced by keying in their names. This is particularly helpful as staff can trace the saving history of different clients and advice the customers in case of any problems or issues.

There are several issues that may face by the Islamic banks in implementation of CRM such as the absence of sufficient human resource and lacked the general knowledge on the best practices to achieve the better performance. The systems and technology embedded in CRM will support the existence of human personnel to maintain the personalized services. Meanwhile, the Islamic banks offered the highest level of customer service to their clients; thus, CRM is a right system to use in accommodating any expectations. Additionally with the emergence of the online platform including social media, the Islamic banks have to improve the quality of their interaction with customers.

The CRM system is designed to compile customer data and information through different channels, which connect the company and customers. The channels include live chat, social media, marketing materials, emails, telephone, and the company's website. The systems also provide the customer services staff with data that will improve the experience of the client. Through this system, the company is able to complete customer's information on their personal information, buying preferences and purchase history. Thus, the systems deliver various benefits especially in creating a personalized experience.

In Islamic view, CRM is complied with the shariah where more benefits can be obtained by the ummah (society). Maintaining relationships with customers and enhancing easy ways in dealings are considered as bringing the goodness to all people. Islam encourages Muslims to involve in a good intention, process, and actions, which results valuable outcomes that are not harming others. All of this can be done and achieved through CRM implementation.

\section{Conclusion}

The Islamic banks realized the importance of CRM to the organization and the customers. Organizations in today's world must remain responsive to the dynamic needs of the customers. Through applications or platforms provided in the CRM, all information related to customers' preferences and expectations are available and can be used to create a personalized experience. Thus, CRM concept is a way to help companies in anticipating the same needs and desires of their future customers.

The results and discussions in this chapter suggest that many of the Islamic banks are concerned on the implementation of CRM and admitted its usefulness in a bigger context. It can also be adopted to create competitive advantage that will develop the Islamic banks. CRM is a continuous learning process aimed at increasing the understanding and knowledge of a company's client. It is a complex issue, which requires a holistic approach in the transformation of the culture of customers. In general, CRM is an increasingly important aspect to the Islamic financial institutions that will improve the company's chances of retaining and attracting new customers. 
Customer Relationship Management Practices in Islamic Banks

DOI: http://dx.doi.org/10.5772/intechopen.89225

\title{
Author details
}

\author{
Ahmad Rafiki \\ Faculty of Economics and Business, Universitas Medan Area, Medan, Indonesia \\ *Address all correspondence to: hahmadrafiki@gmail.com

\section{IntechOpen}

(C) 2019 The Author(s). Licensee IntechOpen. This chapter is distributed under the terms of the Creative Commons Attribution License (http://creativecommons.org/licenses/ by/3.0), which permits unrestricted use, distribution, and reproduction in any medium, provided the original work is properly cited. (c) BY 


\section{References}

[1] Chen QHM. Exploring the success factors of E-CRM strategies in practice. Database Marketing \& Customer Strategy Management. 2004;11(4): 67-88

[2] Alshawi S, Missi F, Irani Z. Organizational, technical and data quality factors in CRM adoption SMEs perspective. Industrial Marketing Management. 2011;40(3): 376-383

[3] Alt R, Puschmann T. Successful practices in customer relationship management. In: Paper Presented at The Proceedings of the 37th Hawaii International Conference on System Sciences. 2004. pp. 1-9

[4] Eid R. Towards a successful CRM implementation in banks: An integrated model. The Service Industries Journal. 2007;28(8):1021-1039

[5] Kim BY. Mediated effects of customer orientation on customer relationship management performance. International Journal of Hospitality \& Tourism Administration. 2008;9(2): 192-218

[6] Moreno A, Meléndez PA. Analyzing the impact of knowledge management on CRM success: The mediating effects of organizational factors. International Journal of Information Management. 2011;31(1):437-444

[7] Brink A, Berndt A. Relationship Marketing and Customer Relationship Management. Cape Town: Juta Publications; 2009

[8] Sinkovics RR, Ghauri PN, editors. New Challenges to International Marketing. United Kingdom: Emerald Group Publishing Limited; 2009

[9] Peppers D, Rogers M. Managing Customer Relationships: A Strategic
Framework. United Sates: John Miley \& Sons; 2011

[10] Pradan S. Retailing Management: Text \& Cases. 3rd ed. New Delhi: Tata McGraw-Hill Education; 2009

[11] Shao B, Yu T. The Theory and Practice of CRM. Beijing: Tsinghua University Publishing Corporation; 2004

[12] Kim J, Suh E, Hwang H. A model for evaluating the effectiveness of CRM using the balanced scorecard. Journal of Interactive Marketing. 2003;17(2):5-19

[13] Shang SSC, Chen CH. Human processes in customer relationship management. In: Paper presented at the proceedings of the 11th Pacific-Asia conference on information system. 2007

[14] Adam AS, Stalcup LD, Lee A. Customer relationship management in Hong Kong. International Journal of Contemporary Hospitality Management. 2010;22(2):139-159

[15] Ramani G, Kumar V. Interaction orientation and firm performance. Journal of Marketing. 2008;72(1):27-45

[16] Goldenberg BJ. CRM in Real Time: Empowering Customer Relationships. Information Today, Inc.; 2008

[17] Raab G, Ajami RA, Gargeya V, Goddard GJ. Customer Relationship Management: A Global Perspective. United Kingdom: Gower Publishing; 2008

[18] Grant GB, Anderson G. Customer relationship management: A vision for higher education. In: Katz RN, editor. Web Portals and Higher Education: Technologies to Make it Personal. San Francisco: Jossey-Bass; 2002. pp. 22-32

[19] Schermerhorn JR Jr. Management. 9th ed. Hoboken, NJ: Wiley; 2008 
[20] Nickels WG, McHugh JM, McHugh SM. Understanding Business. 8th ed. Boston: McGraw-Hill Irwin; 2008

[21] Nalan IŞIK. Growth, Islamic banking and Schumpeterian vision: An empirical evidence from the Gulf Arab states. Uluslararası İslam Ekonomisi ve Finansı Araştırmaları Dergisi. 2018;4(1): 41-56

[22] GIFR, Global Islamic Finance Report (2017) http://www.gifr.net/gifr_2017. htm

[23] FSA (2017), Financial Services Authority (Otoritas Jasa Keuangan). Retrieved from: https://www.ojk.go.id/e $\mathrm{n} /$ berita-dan-kegiatan/publikasi/Doc uments/Pages/Snapshot-of-IndonesiaIslamic-Banking-Development-2017/ Indonesia\%20Islamic\%20Banking\% 20Snapshot\%202017\%20(V3).pdf

[24] Dusuki AW, Abdullah NI. Why do Malaysian customers patronize Islamic banks? International Journal of Bank Marketing. 2007;25(3):143-160

[25] Erol C, Kaynak E, El-Bdour R. Conventional and islamic banks: Patronage behavior of Jordanian customers. International Journal of Bank Marketing. 1990;8(5):25-35

[26] Wang Y, Feng H. Customer relationship management capabilities measurement, antecedents and consequences. Management Decision. 2012;50(1):115-129

[27] Gupte M. Mapping of information flow in customer relationship management tool [Master thesis]. Binghamton University State University of New York; 2011

[28] Becker JU, Greve G, Albers S. The impact of technological and organizational implementation of CRM on customer acquisition, maintenance, and retention. International Journal of
Research in Marketing. 2009;26(3): 207-215

[29] Nath V, Guganani R, Goswami S, Gupta N. Management practices in selected Indian services industries. Journal of Marketing Communications. 2009;4(3):18-40

[30] Payne A, Frow P. Customer relationship management: From strategy to implementation. Journal of Marketing Management. 2006;22(1): 135-168

[31] Croteau AM, Li P. Critical success factors of CRM technological initiatives. Canadian Journal of Administrative Sciences. 2003;20(1):21-34

[32] Abbott J, Stone M, Buttle F. Customer relationship management in practice a qualitative study. The Journal of Database Marketing. 2001; 9(1):24-34

[33] Chen IJ, Popovich K. Understanding customer relationship management (CRM): People, processes and technology. Business Process Management Journal. 2003;9(5): 672-688

[34] Chen M. Factors affecting the adoption and diffusion of XML and web services standards for E-business systems. International Journal of Human-Computer Studies. 2003;58(3): 259-279

[35] Daniel E, Wilson H. Adoption intention and benefits realized: A study of ecommerce in UK SMEs. Journal of Small Business and Enterprise Development. 2002;9(4):331-348

[36] Dasgupta S. Information technology adoption in the Greek banking industry. Journal of Global Information Technology Management. 2000;3(3): 22-30

[37] Eckerson W, Watson JH. Harnessing customer information for 
strategic advantage: Technical challenges and business solutions. In: TDWI industry study report. Data Warehousing Institute; 2000

[38] Goodhue LD, Wybo DM, Kirsch JL. The impact of data integration on the costs and benefits of information systems. MIS Quarterly. 1992;16(3): 293-311

[39] Goodhue LD, Wixom HB, Watson JH. Realizing business benefits through CRM: Hitting the right target in the right way. MIS Quarterly Executive. 2002;1(2):79-94

[40] Irani Z, Love PED. The propagation of technology management taxonomies for evaluating investments in information systems. Journal of ManagementInformation Systems. 2001;17(3):161-177

[41] Kalakota R, Robinson M. EBusiness: Roadmap for Success. Harlow: Addison Wesley; 1999

[42] Lai F, Hsieh CT. On network external, e-business adoption and information asymmetry. Industrial Management \& Data Systems. 2007; 107(5):728-746

[43] Levy M, Powell P, Yetton P. SMEs: Aligning IS and the strategic context. Journal of Information Technology. 2001;16:133-144

[44] Lin CS. Organizational, Technological, and Environmental Determinants of Electronic Commerce Adoption in Small and Medium Enterprises in Taiwan. Florida, United States: Lynn University; 2006

[45] Lucchetti R, Sterlacchini A. The adoption of ICT among SMEs: Evidence from an Italian survey. Small Business Economics. 2004;23:151-168

[46] Scupola A. The adoption of internet commerce by SMEs in the south of Italy:
An environmental, technological and organizational perspective. Journal of Global Information Technology Management. 2003;6(1):3-18

[47] Shang S, Seddon P. Assessing and managing the benefits of enterprise systems: The business manager's perspective. Information Systems Journal. 2002;20(12):271-299

[48] Themistocleous M. Justifying the decision for EAI implementations: A validated proposition of influential factors. Journal of Enterprise Information Management. 2004;17(2): 85-104

[49] Wainwright D, Green G, Mitchell E, Yarrow D. Toward a framework for benchmarking ICT practice, competence and performance in small firms, performance management. The International Journal for Library and Information Services. 2005;6(1):39-52

[50] Wilson H, Danial E, McDonald M. Factors for success in customer relationship management (CRM) systems. Journal of Marketing Management. 2002;18(1):193-219

[51] Buttle F. Customer Relationship Management Concepts and Tools. Oxford, United Kingdom: Elsevier Butterworth Heinemann; 2004

[52] Mendoza LE, Marius A, Perez M, Griman C. "Critical success factors for a customer relationship management strategy", Information and Software Technology. 2007;49(8):913-945

[53] Kim HS, Kim YG, Park CW. Integration of firm's resource and capability to implement enterprise CRM: A case study of a retail bank in Korea. Decision Support Systems. 2010; 48(2):313-322

[54] Sohrabi B, Haghighi M, Khanlari A. Customer relationship management maturity model (CRM3): A model for 
stepwise implementation. International Journal of Human Sciences. 2010;7(1): $1-20$

[55] Kale SH. CRM failure and the seven deadly sins. Marketing Management. 2004;13(5):42-46

[56] Cai S. The importance of customer focus for organizational performance: A study of Chinese companies.

International Journal of Quality \& Reliability Management. 2009;26(4): 369-379

[57] Day George S, Van den Bulte C. "Superiority in Customer Relationship Management: Consequences for Competitive Advantage and Performance", Marketing Science Institute, Research International and the Mack Center for Technological Innovation at the Wharton School, pp.1-49

[58] McNally RC. An exploration of call Centre agents' CRM software use, customer orientation and job performance in the customer relationship maintenance phase. Journal of Financial Services Marketing. 2007; 12(2):169-184

[59] Faed A, Radmand P, Talevski A. The critical success factors for implementation of CRM and knowledge management in a work setting. In: International Conference on P2P, Parallel, Grid, Cloud and Internet Computing. 2010. pp. 140-148

[60] Rigby R, Reichheld F, Schefter P. Avoid the four perils of CRM. Harvard Business Review. 2002;80(2):101-109

[61] Plakoyiannaki E, Tzokas N, Dimitratos P, Saren M. How critical is employee orientation for customer relationship management? Insights from a case study. Journal of Management Studies. 2008;45(2):268-293

[62] Almotairi M. CRM Success Factors Taxonomy. Dubai, UAE: European and
Mediterranean Conference on Information Systems; 2008

[63] Capacity OA. An empirical study of the relationship of it intensity and organizational absorptive capacity on CRM performance. Journal of Global Information Management. 2004;12(1): 1-17

[64] Chang HH. Critical factors and benefits in the implementation of customer relationship management. Total Quality Management \& Business Excellence. 2007;18(5):483-508

[65] Chang HH, Ku PW. Implementation of relationship quality for CRM performance: Acquisition of BPR and organizational learning. Total Quality Management \& Business Excellence. 2009;20(3):327-348

[66] Kennedy A, Kelleher C, Quigley M. CRM best practice: Getting it right first time at ESB international (ESBI). Irish Journal of Management. 2006;27(1): 255-272

[67] Yim FH, Anderson RE, Swaminathan S. Customer relationship management: Its dimensions and effect on customer outcomes. Journal of Personal Selling and Sales Management. 2005;24(4):265-280

[68] Zablah RA, Bellenger ND, Johnston JW. An evaluation of divergent perspectives on customer relationship management: Towards a common understanding of an emerging phenomenon. Industrial Marketing Management. 2004;33(6):475-489

[69] Liu H. Development of a framework for customer relationship management (CRM) in the banking industry. International Journal of Management. 2007;24(1):15

[70] Siegele L. Always-on people: A big part of running a real-time enterprise 
will bemanaging relationships. London: The Economist; 2002

[71] Cavalcanti, G.. Barriers to implementation of information and communication technologies among small-and medium-sized enterprises: The digital divide through the business lens, MBA Thesis. California State University, Fresno, CA; 2006

[72] Ndubisi NO, Jantan M. Evaluating IS usage in Malaysian small and mediumsizedfirms using the technology acceptance model. Logistics Information Management. 2003;16(6):440-450

[73] Utomo H. Contributing factors to the diffusion of IT within small- and mediumsizedfirms in Indonesia. Journal of Global Information Technology Management. 2001;4(2):17-32

[74] Buonanno G, Faverio P, Pigni F, Ravarini A, Sciuto D, Tagliavini M. Factors affecting ERP systems adoption: A comparative analysis between SMEs and largecompanies. Journal of Enterprise Information Management. 2005;18(4):384-426

[75] Nelson SD, Kirkby J. Seven Key Reasons Why CRM Fails. Gartner; 2001

[76] Ryals L, Payne A. Customer relationship management in financial services: Towards information-enabled relationship marketing. Journal of Strategic Marketing. 2001;9(1):3-27

[77] Peikin D. Data quality: The foundation for effective CRM. Target Marketing. 2003;26(2):49-50

[78] Bose, U. and P. Chong. A Policy for Managing Data Quality to Improve Customer Relationship Management. 2003. Available at: http://iacis.org/iis/ 2003/bosechong.pdf

[79] Jayachandran S, Sharma S, Kaufman P, Raman P. The role of relational information processes and technology use in customer relationship management. Journal of Marketing. 2005;69:177-192

[80] Roh TH, Ahn CK, Han I. The priority factor model for customer relationship management system success. Expert Systems with Applications. 2005;28(4):641-654

[81] Reinartz W, Krafft M, Hoyer WD. The customer relationship management process: Its measurement and impact on performance. Journal of Marketing Research. 2004;XLI:293-305

[82] Sang Long C, Khalafinezhad R, Wan Ismail WK, Abd Rasid SZ. Impact of CRM factors on customer satisfaction and loyalty. Asian Social Science. 2013; 9(10):247-253

[83] Verhoef P. Understanding the effect of customer relationship management efforts on customer retention and customer share development. Journal of Marketing. 2003;67:30-45

[84] Keramati A, Mehrabi H, Mojir N. A process-oriented perspective on customer relationship management and organizational performance: An empirical investigation. Industrial Marketing Management. 2010;39: 1170-1185 


\title{
Customer Satisfaction with Online Retail Transactions
}

\author{
Titus Okeke
}

\begin{abstract}
The development of information and communication technology (ICT) and its wide application in marketing led to the development of online retailing where customers now shop from the convenience of their homes and/or offices. This has redefined customer satisfaction as customers can go online to read and learn product reviews before making purchases. With the emergence of social media, customer engagement is rife and can create value for the firm. Several models have been employed in studying customer satisfaction with online retailing. These include the disconfirmation of expectations model, perceived performance model, rational expectations model, expectations-artifact model, attribution model, cognitive dissonance model, comparison level model, contrast model, and the Kano model. This chapter is on customer satisfaction with online retail transactions. It looked at the concept, models, and customer engagement; and stressed the need for a holistic/multidimensional approach to engagement as a way of enhancing engagement in the present information, communication and technology (ICT)-driven age. The methodology involves the review and analysis of published works/researches and reports as well as review and analysis of messages and posts by online vendors to customers. It also includes observations and notice of transactions from customers as they receive wares from online vendors.
\end{abstract}

Keywords: customer, consumer, satisfaction, loyalty, engagement, ICT, technology, web, online, POS, retail, products, services

\section{Introduction}

Customer satisfaction is a customer's feelings of pleasure or disappointment from consuming a product or service and comparing perceived outcome to expectations. Where the experience falls short of expectations, the customer is dissatisfied. If the consumption meets the customer's expectations, the customer is satisfied. If it exceeds expectations, the customer is highly satisfied or delighted. Customer satisfaction is the ultimate aim of any business organization the world over [1]. Of a truth, it is the rationale behind the existence of any business in the first instance. Whenever indicators like productivity, profitability, sustainability, and the likes are being considered in the world of business, no organization dares neglect the fact that customer satisfaction plays a significant role in affecting these indicators. Fronting such goals as productivity, profitability, and growth as the major pursuits of an organization with less attention on satisfying customers is an exercise in futility.

With the rise in technology as a transformative force and its attendant effect on the way humans live, work, and interact, ICT has influenced the manner at which business is been done globally and the case is not different for Nigeria and other 
emerging markets of the world. Also, an increase in global retailing both in terms of their point-of-supply and point-of-sale has dramatically increased the amount of and the application of ICT in the retail sector [2]. Arguably, ICT plays a germane role in the management of complex retail operations. Absolute data control and information, as well as adequate market knowledge, is paramount in the course of obtaining a competitive edge in the retail sectors as the market continues to grow and become more sophisticated [3]. ICT can be deployed to cope with all the transactions that could be involved. Retailers have beginning to appreciate the role of ICT as a major enabler in the course of speeding up processes and cost savings to the business. This becomes a major rationale behind the speedy adoption of ICT in the conventional retail sector [2].

Put explicitly, online retailing has become a significant part of the daily activities of business organizations. Access to various online retail platforms is seen as a necessity rather than a form of luxury especially among the urban dwellers [2,3]. And one of the major determinants of the growth of online retailing and ICT are inseparable because online retailers absolutely depend on ICT for their operations and intensifications [4]. In addition, online retailing focuses on the application of ICT to facilitate the transaction and interaction between the business and the customers. Conclusively, ICT is a veritable tool for achieving an effective and robust online retail transaction; it is the live wire of any successful online retail transaction. The application of ICT to retailing is further defining customer satisfaction, loyalty, and engagement; and the extent of application is frankly speaking limitless. Accordingly, online retail transactions in this study refer to all activities by retail customers on the Internet and include buying from online shops, payments and receipts online like automated teller machine (ATM) banking, mobile banking/money, web banking and point of sale (POS) transactions. This chapter is divided into five sections. Following this Introduction is Concepts of customer satisfaction in Section 2; Models of customer satisfaction in Section 3; Customer satisfaction and customer engagement in Section 4; and Conclusion in Section 5.

\subsection{Methodology}

The methodology involves the review and analysis of published works/ researches and reports as well as review and analysis of messages and posts by online vendors to customers. It also includes observations made and taken note of as customers receive wares ordered from online vendors. Analysis of secondary data aims at patterns or trends across the results, tracking progressions through time and is aimed at seeking out repetitions of certain results to build up a case. Of the many different ways to analyze secondary data, many are not different from those used for primary data. The methodology in this paper involves analysis that consists of an examination of what can be counted in published texts and researches. Thus, this methodology involved an analysis of researches, reports, and other publications as they relate to customer satisfaction with online transactions. It also involves analysis of reported cases of online transactions as reported by the Central Bank of Nigeria $(\mathrm{CBN})$ in some of their published reported relating online transactions especially online payments which drive other online transactions.

\section{Concepts of customer satisfaction}

Customer satisfaction simply means giving the users or the final consumers of firms' products and services what they need or want with precision [5]. It involves 
mainly about meeting their demands and taste, that is, the input and the thru put must produce an output that meets up with the customers' expectations. Precisely, customer satisfaction denotes meeting customers' expectations and ought to be an ongoing and reviewed process for firm's acceptance and survival.

Before marketing concept stage where needs and wants are put into consideration before actual production of goods and services are various stages through reliable research work [6]. The rationale behind this exercise is to ensure seamless marketing and avoid marketing costs that are not necessary. One wonders why firms budget huge money for sale promotional activities, advertisement, customer relations, etc. while it is easier and cheaper in terms of time and money to go into research in order to ascertain what product(s) is/are next in the customers' minds. Put pointedly, it is an aberration for any firm to assume that customers will buy products that do not meet their taste or satisfy their needs or wants. In fact, there is a paradigm shift from the old satisfying product(s) to a new more satisfying product. For example, flat screen television used to be a satisfying product a decade ago, but currently, consumers are demanding for just a flat-screen television set but a more satisfying smart television set (Internet-enabled flat-screen television) [1]. There is no breaking force as potent as breaking customers' loyalty when it comes to products that emanated through research and consider customers' image. It is a known fact that no business firm would like to manufacture products that do not satisfy the customers in the first instance; however, the modalities to follow is a major concern.

It is expedient to put into consideration that the cogent point for satisfying a customer is that business organizations must maintain and sustain a personal and cordial relationship with the customers. Marinating personal and hitch free relationships do not only retains and keeps them satisfied with the organization's product(s) but it serves as a free source of a promotional tool for the organization [5]. It is an established fact that word-of-mouth is the most effective and efficient means of promotion because words from the loved ones and one's reference and peer groups are more trusted than any form of advertisement or sales promotion. So, it creates not only brand loyalty for the organization but also enjoying "free" publicity from the existing customers.

Furthermore, it is necessary for business firms to monitor the satisfaction of their customers as it allows the managers to analyze the strengths, weaknesses, opportunities, and threats of the firm, areas of improvement in order to maximize the potentials of the business, and eventually maintain, sustain or increase its probability of success in the market. It is essential for organizations to gauge the satisfaction of its customers in the bid to retaining them, as well as attracting prospects via recommendations and positive word-of-mouth from existing satisfied customers. Concentrating on customer satisfaction also enables managers to appraise the development of a business firm as a going concern and serves as a yardstick to measure the performance of its workforce [6].

Although, the majority of business owners strongly believe that customer satisfaction is germane, can they really support this for certain reasons? Some of them may respond causally that customer satisfaction is necessary "just because..." however, evident reasons abound why business firms need to make their customers happy [5]. First, do not forget that the large chunk of most business so, there is need for strong repeat business (purchase) base in order to cushion the effect of the comings and goings of new and short-term customers. Second, a satisfied customer is a happy customer; a happy is a good promoter. Customer satisfaction is important because it is an avenue for a happy customer to tell other people about the organization products. Happy customers buy more of the company products and the firm could gain or lose prospects based on words from another customer. 
Another cogent reason for customer satisfaction is that organizations must remain faithful and truthful to their customers. Most businesses, especially small businesses, do cheat their customers for a meager amount of money, but in the long run, they lose their regular customers, which eventually leads to the loss of goodwill, corporate image, and ultimate collapse of the business. Goodwill is one of their promises in order to maintain prosperous goodwill. Being a good listener is the area where most firms are deficient. Any organization that is a good listener should have its motto as customers' satisfaction instead of focusing on revenue generation, being a good listener will further help a firm to track the present market trends by understanding the demands of the customers. Customer satisfaction is the only sure bet for surviving in the turbulent business environment and escape the cut-throat completion in the market.

\subsection{Customer satisfaction and customer loyalty}

Customer satisfaction is a customer's positive, neutral or negative feeling about the value received from an organization's product in specific use situations [7]. Also, customer satisfaction could be described as a feeling of pleasure or disappointment that results from a company product performance to expectations. If a customer perception about a certain product is better than expectation, he/she is delighted, if it as expected, they will be satisfied, if it is less than expected, they will be dissatisfied [8].

Conversely, customer loyalty refers to what is occurring over time between a customer and an object in the market (a supplier, brand, a store, etc.). It also reflects an emotional and business attachment to the service firm [9]. Furthermore, customer loyalty is the deeply held commitment to re-buy a preferred product in the future despite situational influences and marketing efforts having the potential to cause switching behavior. Accordingly, a customer can be loyal to brand, a product/ service, a company and the product environment.

Looking at the relationship between satisfaction and loyalty, in most cases, it is non-linear. Satisfied customers are not always guaranteed to be loyal. However, a higher level of satisfaction could lead to more loyal customers especially in the industrial market and service sectors. These imply that the relationship or link between satisfaction and loyalty is a function of the product and market categorization. A study [10] to investigate the relationship between satisfaction and loyalty among the bank customers revealed that there exists a strong and positive relationship between satisfaction and loyalty. An empirical study [8] on the association between customer satisfaction and customer loyalty using the American customer satisfaction index data and various customers, firms and industry indicators showed that the actual nature of the association or relationship that exists between satisfaction and loyalty has a satisfaction impact on competitive setting differences. This implies that the business environment and the tone of competition that exist therein influence the link between satisfaction and loyalty.

Furthermore, a study [7] on the relationship between customer satisfaction and customer loyalty among service customers using the emotional brand image as the moderator reveal that customer satisfaction and emotional brand image have a significant effect on customer loyalty [9]. Further posits that the relationship between customer satisfaction and customer loyalty in the Indian commercial vehicle industry is positively strong especially in the industry where prices are more or less the same among the major players [11]. Similarly, in a study on service quality dimensions and customer satisfaction online service quality dimensions of Nigerian Banks, Okeke et al. [12] found that tangibles, price, security, and perceived risks are significant predictors of satisfaction in online banking. Initially, a reviewer in 
the earlier version of the study raised the question whether price is a service quality variable and the answer was in the affirmative.

In conclusion, the relationships that exist between customer satisfaction and customer loyalty are premised on the kind of product categorization, absence or presence of moderating factor(s), the circumstances, and the market type.

\section{Models of customer satisfaction}

Several models have been used in consumer satisfaction studies. These include the disconfirmation of expectations model, perceived performance model, rational expectations model, expectations-artifact model, attribution model, cognitive dissonance model, comparison level model, contrast model, and the Kano model. Others include the planned behavior models, reasoned action models, technology acceptance models and its various extensions. Other models used in consumer satisfaction studies are the service quality (SERVQUAL) model in its various forms like the electronic service quality (e-SERVQUAL) among others. Whereas some of these models emanate from the brick and mortar retail traditions, they have been employed in measuring customer satisfaction and loyalty with the emergent online retail industry. Some of these models are discussed.

\subsection{The disconfirmation of expectation model}

This model was developed structurally in a series of two papers written by Oliver [13]. It is a cognitive theory that seeks to describe post-purchase or post-adoption satisfaction as a function of expectations, perceived performance, and disconfirmation of beliefs. In other words, it shows how customer satisfaction is affected by the summation of product performance and customer's expectation level. The model submits that in a situation where the performance that a customer perceives is adjudged to be higher than the expectations obtained, satisfaction will rise. This is known as positive disconfirmation. However, when a perceived performance is lesser than the customers' level of expectation, the result will be a decrease satisfaction hence, negative disconfirmation $[13,14]$. Therefore, satisfaction is a function of the disparity between performance and expectations, and satisfaction is indicated by the disconfirmation model; it forecasts that as expectations rise, satisfaction will decline.

This review of literature on customer satisfaction model outlines that besides job satisfaction literature, disconfirmation of expectation model has enjoyed widespread support from scholars in other fields, and it has been generally used in appraising and measuring satisfaction with diverse products, like the hospitality sector [15-19] and restaurant services [20-22], in the automobile industry [23] and stock market services [24]. However, the disconfirmation of expectations model has been scarcely used in the field of Internet marketing, sustainability marketing, health marketing, and social marketing.

\subsection{The perceived performance model}

This model has deviations from the disconfirmation of expectations model in that the role expectation plays in satisfaction formation is less significant [13]. It conceptualizes the theory that the perception of customers about certain product performance and their expectations pertaining to that performance have a positive impact on customer satisfaction. Performance is seen as the product's quality level, from the perception of the customer, in relation to the price paid. The perceived 
performance is explained to be the value, that is, benefits gained for incurring costs. The higher the ability of the product, in relation to the cost, the more satisfied the customer becomes. More so, the perceived performance model is more applicable in scenarios where a product performs nicely that the expectations of the consumers get discounted in his/her post-consumption relations to the product. The perceived performance model displays that expectations are having a direct and positive effect on satisfaction due to the pivotal role it plays in the process of evaluating satisfaction [13]. The model also portrays that the stronger an expectation of a customer, in relation to the performance information, the greater the effect of expectations as a pivot in the process of satisfaction evaluation. The model shows that expectations have a positive effect on the perceived performance-the capacity of customer expectation as a predictor of performance. This is mostly experienced when a customer has a wealth of experience with a performer that is either predictable or has less variance. This model has more application in the fast moving consumer goods (FMCG) sector than sectors that involves complex and heterogeneous service like project management because the extent of the effect of performance varies from products or sectors.

\subsection{The rational expectations model}

This model proposes that the average expectations of an agent in a given market are equal to the outcomes of that market [25]. From the macroeconomic perspective, the rational expectation model postulates that each person bases his/ her decisions on three major factors: human rationality, information availability, and past experience. Applying these propositions to the online retailer-shopper relationship, it can be said that the expectations of the online retailer's actual performance are in the course of rendering the service. According to the rational expectation model, the whole market expectation can be greater than the sum of expectation of each customer [26]. It is believed that the totality of the market is believed to be more rational and accurate than that of individual consumers [27]. The rational expectation model asserts that perceived performance and expectations are immaterial because they equate each other and both have a single positive effect on satisfaction [25-27]. This model is used mostly in the field of macroeconomics, micromarketing with less application in the field of micromarketing and social marketing.

\subsection{The expectations-artifact model}

There should not be either a positive or negative effect of expectations on satisfaction, especially in a unique service sector live construction management and other heterogeneous service sectors [13]. This is because, in the context of most heterogeneous service sectors, expectations do not necessarily act as the pivot like in the perceived performance model or as a standard measure for comparison like in discomforting of expectations model, while evaluating or appraising satisfaction. Performance will result in the expectations as reported by the customers [13]. The expectations-artifact model demonstrates that there exists a direct and positive effect of perceived performance on satisfaction and that performance and expectations have a positive relationship. The model further states that expectations cannot be linked with satisfaction since it does not have any effect on satisfaction. This implies that focusing on expectations would be a wasted effort in the course of enhancing or improving customer satisfaction levels. The model postulates that expectations are the output of the service production process, have no direct effect on customer service, and any attempt to meet or surpass customer expectation is 
needless. Rather, the model asserts that in order to improve customer satisfaction, the focus of any organization should be on performance improvement.

\subsection{The attribution model}

This model was postulated [28]. The model posits that customers are perceived to be rational information processors who always look out for a reason to explain or justify their purchase outcome (satisfaction or dissatisfaction). The model submits that customers do engage in an attributional process when service delivery is not in congruence with their prior expectations. The model also assumes that consumers usually search for the cause of a product's success or failure and attribute the success or failure using locus of causality (internal and external), stability, and controllability.

It is further argued that in a situation whereby the customer agrees with the cause of his/her dissatisfaction, the firm makes the same mistakes repeatedly, the external attribution process begins. Conversely, in a scenario where agreement, consistency, and distinctiveness are low, consumers tend to link their negative reactions to themselves. The attribution model has been previously used in predicting consumer level of dissatisfaction rather than explaining and describing the satisfaction process. We suggest that current studies should focus on the applicability of this model in predicting consumer satisfaction, especially in the online retailing studies.

\subsection{Cognitive dissonance model}

This model was propounded by Yuksel and Yulsel [29]. The model posits that people possess a motivational drive to alleviate dissonance by altering their attitudes, beliefs, and behaviors, or by rationalizing or justifying them. From the consumer behavior perspective, cognitive dissonance is a psychologically uncomfortable state that arises from the existence of contradictory (dissonant) relations among cognitive elements. The model explicitly explains the state of discomfort purchasers mostly find themselves after making a purchase decision. Even though cognitive dissonance is an established construct in the field of marketing, its usage in empirical marketing research is relatively scanty. The reason being that dissonance is a mere transitory phenomenon and it is very difficult to measure dissonance or operationalize it using a quantitative and empirical method.

\subsection{The comparison level model}

This model of customer satisfaction was propounded by Thibaut and Kelly [30]. The model was developed to correct the anomalies of expectation of the disconfirmation model. The model posits that the basic determinants of a product comparison level are more than one as follows:

i. Prior experiences of a consumer with similar products

ii. Situationally generated expectations

iii. Other consumers' experience serves as a reference group

The model asserts that norms play a significant role as a basis for comparing various consumers' satisfaction judgments. The model further revealed that situationally produced expectations have less effect on customer satisfaction, while 
expectations that are based on previous experience were the paramount predictor of customer satisfaction. The model further suggests that different comparison standards may be brought into the consumption experience by the consumer. Also, consumers might possibly employ predictive expectations on the basis of external communication prior to purchase, while various standards (past experiences, other significant consumers' experience) might possibly surface after the purchase. However, there is no adequate information to confirm or disconfirm the standards that consumers bring into the consumption experience. The theoretical implication of this is that the comparison standard in customer satisfaction discourse may help managers to carry out a comparative analysis between their performance and that of their rivals and undergo necessary actions for product/service differentiation.

\subsection{The contrast model}

This model was introduced by Hovland et al. [31]. This model postulates that whenever an actual product performance is short of the consumers' expectations, the discrepancy between the expectation and the result will cause the consumer to magnify the disparity. The model further posits that when the value gain from consuming a product is lesser than expected, the customer will exaggerate the difference between the product received and the product expected, and contrast model further predicts that products that perform below expectation will be rated poorer than it is in the actual sense. This is a result of the surprise effect on the part of the consumers that leads to the exaggeration of the discrepancy.

If a firm's expectation is raised through its advertisement and the customers' experience is a little lower than the firm's promise, the product would be rejected and become absolutely unsatisfactory. Conversely, under-promising in order to over-deliver in advertising will lead to positive disconfirmation also being magnified. Constructively, the contrast model has been criticized in that it has been mostly used in laboratory settings where customer satisfaction is highly manipulated, situation specific, and individually focused. It is not certain whether the hypothesis hold by this model could be tested in the field survey study like online shopping behavior and others. More so, the contrast model predicts customer reaction rather than dissonance reduction.

\subsection{Kano model}

According to Prasad [32], Kano model of customer satisfaction was propounded by Noriaki Kano in 1984. The model groups attributes of a product on the basis of customer perception and their effect on customer satisfaction. These groupings are germane for guiding design decisions because they help in indicating how good a product is and when there is a need for more. This model posits that there exists a non-linear relationship between product performance and customer satisfaction. The model further categorizes product attributes into five groups:

Threshold attributes that the customers are expecting and are necessities of a product.

Performance attributes for which the more the product delivers, the merrier it becomes. The better fulfillment results in a direct increment of customer satisfaction and non-existence or weak performance of these attributes will automatically lower the customer satisfaction level.

Excitement attributes are attributes that the customer never expected. Their presence usually makes the customer highly satisfied and eventually delighted.

Indifferent attributes are those that are negligible because they do not practically belong to any of the other attribute categories, though they influence decision making. 
Reverse attribute refers to a high level of achievement leading to dissatisfaction on the basis that not all customers are exactly the same.

Kano model predicts that an attribute will transmit from one category to another over time. This transition is propelled by the expectations of customers and the performance level from competing brands or products. The Kano model has been widely applied in online retail studies like $[33,34]$ and $[34]$ in online service convenience.

\section{Customer engagement and customer satisfaction}

Presently, customer engagement is becoming popular and widely used in various fields of study. CEOs, marketing experts, advertising gurus, and web analytics professionals use the term haphazardly. It can be clumsy to see the same word being used in different scenarios [35]. The diverse meanings of customer engagement unraveled how experts in each field have pinpointed how it should be measured and operationalized.

Primarily, there are three main fields of study that usually use this phase; marketing, advertising, and web analytics and optimization [36]. In these three areas, customer engagement explains the customers/user's experience in the course of consuming a product. Since there are no indices for measuring this term, firms that involve in helping other organizations to design their customer engagement strategy must first key quality indicators, so as to quantify the success. Based on this, the manner at which companies measure customer engagement differs; however, there are few common grounds across the organization. Consumer engagement has received increasing attention from practitioners, academics, and the likes. Consumer engagement/user engagement/or customer engagement has received attention in various online and ICT usage contexts, such as mobile commerce application [37], online brand communities [38], and mobile payment applications [39]. The terms "customer engagement," "consumer engagement," and "user engagement" are used interchangeably in many studies. However, consumer engagement is conceived as a behavioral, cognitive, and emotional process [40]. This increasing attention to consumer engagement is largely due to the fact that, unlike customer satisfaction, consumer engagement targets more long-term interactions as it encourages customer loyalty and advocacy through word of mouth. Below are the definitions of customer engagement from various disciplines with the common features used in measuring it.

\subsection{Customer engagement in advertising}

Customer engagement is an act of turning on a prospect to a brand idea enhanced by the surrounding context [35]. Generally, advertising practitioners use the term customer engagement to describe the manner at which an intending viewer interacts or relates to an advertisement. Early advertising practitioners perceived the advertising purchasing process as relatively one-sided-from catching the customers' attention by Ad designs, interest, and desire stimulation, to drive to purchase. However, contemporary advertising practitioners focus on the people interactions with a particular advertisement using their metaphors associations and symbols combined with the ad's messages. Therefore, an engaged customer is one who has a personal interaction with an advertisement, and who has convincingly made the choice of buying a product. Thus, many companies and organizations devout reasonable percent of their communications budget to online engagement. 
Customer engagement in web analytics/optimization in the realm of web analytics and optimization, customer engagement explores and explains the manner at which a user interests or relates to the website of a particular brand [35]. The main objective of a customer engagement strategy as far as web analytics are concerned is to increase conversion-online sales, sign-ups for e-mail newsletters, and signups for free service trails. Customer engagement is defined by web analytics firms based on diverse indices like the quantity of time each user spends on a website or a particular web page, numbers of web pages viewed, and numbers of posts each user make of the social media outlets [35].

\subsection{Customer engagement in marketing}

From the marketing perspective, customer engagement involves the level of interaction a customer has with a particular brand. Engagement refers to the level of a customer's attention and involvement with a communication [41]. Some online measures of engagements are Facebook "likes," Twitter tweets, comments on a blog or Web site, and sharing of video and/or other content. Engagement can extend to personal experiences that compliment or transform a firm's products and services. In contrast to customer satisfaction and loyalty, customer engagement concentrates more on long-term emotional attachment to a brand or a company by the customers [36]. The high level of customer engagement is a function of increased word-of-mouth referrals, testimonials, and customer advocacy. Thus, it has been reported that when there is a satisfactory relationship between an organization and a customer, an emotional bond is created and this type of relationship can progress to the engagement stage with the potential to generate more revenue, to ensure a lifetime of profitable loyalty [42]. It is not uncommon for CEOs and business executives to be interested in scaling up their customer engagement strategy since it has a positive relationship with key business outcomes like profitability, stock price, return on investment, and earnings per share. Marketers may measure engagement by studying such indicators as customer retention, sales volume and value, revenue per customer, repeat purchase frequency and marketing cost as well as e-mail opt-in and time spent on a particular website [36].

\subsection{Customer engagement: the ICT perspective}

The gradual but steady invasion of technology and the attendant social media into the day-to-day business and marketing activities has altered each of our endeavors from making and receiving a telephone call, doing physical exercise to purchasing groceries [43]. We are constantly depending on technology and other smart devices to help us in organizing, tracking, and managing our daily activities. The use of paper is gradually becoming less important and moribund as the majority of our documents are stored in the cloud. The case is the same for business organizations and their practices are fast changing to meet up with the trend. However, there is still something to be discussed about the human touch', so how is it discussed about the "human touch," so how is customer engagement defined in this virtual world as against the brick-and-mortar world?

Customer engagement can be described as the interactions between a customer and a brand through various means of communication, irrespective of the platform a business operates or a customer uses [43]. The major form of customer engagement is advertising whether online, print, broadcast or any other medium. As business organizations spend more marketing naira on the Internet and social media campaigns advertising is becoming engaging and interactive more especially with online retail outlets and other businesses conducted on the web. 
The technology installed on social media sites enables organizations to monitor and record accurately consumer behavior and channel marketing programs based on customer type, thereby creating a more interactive and real-time experience for the customer [43]. The output is a customer with a high tendency of returning to interact with a specific brand. Through proper utilization and definition of customer engagement, through social media and the Internet, organizations are enabled to collate, track, and decipher customer data meaningfully. This does not only create an avenue for improved marketing but also stronger customer engagement.

The present digital age via the Internet of Things has enabled customers to really interact with brands, products, companies, and even creating communities of like-minded consumers without having any physical contact, thereby enhancing information access that enhances customer satisfaction and in turn loyalty.

One trending activity of customer engagement that is seeing resurgence is the loyalty card program. These are organizations that provide special discounts, perks, information, and other related opportunities for customers that are loyal. In Nigeria, restaurants, hotels, shopping, recreation centers, and lounges are usually involved. Initially, this program made use of plastic bar-coded cards that needed to be presented at the point of purchase. However, the majority of the business organizations are switching to the programs that only require the customers to link their credit or debit card to a particular online portal, and their purchase is easily and continently tracked; no extra card or coupons are required.

By building a steady and reliable interaction between a brand and a customer, loyalty program establishes constant and dependable customer engagement. Firms are able to monitor and record precisely customers' buying behaviors and preferences, hence building the next customers perk. Customers feel rewarded for being loyal with normal buying behaviors. More so, these customers could involve in marketing surveys, social media interaction, and other campaigns. Whenever a business decides to build new customers and retain the existing one, the use of a loyalty program is usually the cheapest. By creating a platform that allows the registering of a credit card, the probability that a customer will sign-up can increase, as there is no additional step to remember in order to get perks. Having a piece of deep knowledge about one's customer base, engaging and rewarding them can be as easy as swiping of a card at a point of sale terminal.

\subsection{Necessities for customer engagement}

It is an established fact that customer engagement is very important for the survival of any business in modern times. Moreover, it is also a known fact that great customer service is a crucial factor for keeping a healthy customer relationship and prospecting new opportunities. This is a statement of fact for our highly connected society. With just one bad customer experience, a company's name can go viral in social media, in a derogatory manner. This is the motivation why smart firms are scaling up their customer service to the next level through the intelligent utilization of information and communication technology since it provides diverse platforms for contemporary firms to initiate and maintain a long-lasting relationship with their customers [43]. Below are the major reasons why customer engagement is necessary [35]?

a. Improves customer satisfaction: organizations that concentrate on enhanced customer engagement do experience geometric growth in their revenue and a boost in customer satisfaction. One of such company's primary goals is to create a persistent, consistent, and superior customer engagement throughout the customer journey. 
b.Encourages customer loyalty: when a customer is fully engaged, he or she becomes loyal. Customers of any brand will continue to improve the well-being of the brand and eventually become loyal if the firm can create an enhanced and impressive customer engagement because an enhanced customer engagement will halt switching behaviors from the customers.

c. Increase revenue and sales: the majority of customers want a fair balance of price and service, and they would not settle for anything less. Customers prefer to engage with brands that make it easy to transact with them by spending more money on such brands. Ultimately, customers value superior service and are willing to pay a premium price for it.

\subsection{ICT and customer engagement}

Technology especially the ICT is offering an important advantage for online retailers in the area of customer engagement by improving and enhancing customer service. Continuous evolvements of technologies have empowered customers than ever [43]. It is not only advantageous to the customers but it also has brought brands to be closer to their customers and providing an avenue to comprehend customers better and keep a track of their behavior in this ever-changing and dynamic communication world [36].

Smart brands that want to make use of technology to resuscitate their customer services must devise means of helping customers to conversate with brands whenever the need arises. Brands should structure their business procedures to accommodate efficiency and cost reduction. Firms need to concentrate on consumer data analytics through insight-driven marketing in order to get better outcomes. As [41], puts it: although Facebook "likes" and Twitter tweets provide some sense of the engagement for a brand, a more complete set of measures is typically needed to get a more accurate picture of social media or other online activities. Smart brands should further encourage their personnel to be proactive and always welcome new ways of improving customer engagement. In the nearest future, organizations that will concentrate on customer engagement will be able to garner maximum profit.

Smart organizations can deploy the use of technology to improve their customer engagement as follows:

a. Organizations can adopt email as a means of enhancing their customer service. This will help them to be responsive to their customers' queries as soon as possible.

b.Smart brands can step-up their customer relationship and engagement by making use of sophisticated data-gathering software like CRM software.

c. By providing fields on the firm's Website where the customers can respond to queries and seek solutions to problems and challenges from other users.

\subsection{Online retailing and transactions in Nigeria}

In recognition of the emergent e-payment services which were at the early stages of development in Nigeria, the CBN in 2003 [44] issued guidelines on the operation of electronic banking in the country. The apex bank in recognition of its roles in the financial system stability and payments system oversight, the CBN Technical committee on e-banking produced a report which anticipates the likely impact of the 
movement toward electronic banking and payments on the achievement of CBNs core objectives. The CBN guidelines on electronic banking are in four categories:

- The Information and Communication Technology (ICT) standards to address issues relating to technology solutions deployed; standards for computer networks and Internet; protocols; application and system software as well as standards on delivery channels like mobile telephone; Automated Teller Machines (ATMs); Internet banking; point of sales (POS) devices; international schemes; electronic bill presentment; switches; Internet service providers; card schemes; and electronic transfer of funds. Also included are standards on security and privacy which includes security policy and privacy; standards on identification; access control; security log/audit trail; backup, recovery and business continuity; and vendors and outsourcing.

- Monetary policy: the guidelines stipulate that electronic money scheme operators must supply the CBN with statistical information, about the volume and value of their transactions, based on agreed format. All categories of electronic money would be treated as part of the reserve requirements. Issues of electronic money are also required or subjected to prudential requirements.

- Legal issues: banks are obliged not only to establish the identity of their customers but also enquire about their integrity and reputation. To this end, there is an obligation on banks to maintain secrecy and privacy/confidentiality of customers' accounts among other legal issues.

- Regulatory and supervisory issues: the guidelines stipulate that in order to mitigate the risks associated with all electronic banking businesses, banks should have in place a comprehensive risk management process that assesses risks, controls risk exposure, and monitors risks. The regulatory and supervisory issue also specifies the modalities for introduction of new e-banking/electronic products and services as well as reporting requirements and penalties for default.

The import of the above is that online retail transactions are multiple and varied as we have explained above; and electronic payments drive the emergent online retailing. In other words, banks are central to online retailing and are also critical success factors in customer satisfaction with online/e-commerce operations.

Nigeria's Internet penetration rate between 2010 and 2019 is 59,653\%, which is higher than the $11,532 \%$ penetration rate for Africa over the same period [45]. Also $59.5 \%$ of the estimated population of 200.1 million people in March 2019 use the Internet; while only 17, 000,000 people are Facebook subscribers as at December 31, 2018. Despite poor Internet infrastructure, the proportion of Internet users in Nigeria is above Africa's rate of $39.8 \%$ and World rate of $57.3 \%$ as at 30 th June, 2019. Arguably, this rapid growth in the adoption of Internet is redefining the way Nigerians buy and consume. Indeed, the evolving online retailing and other online financial transactions in Nigeria is becoming a phenomenon. The Internet has brought about the emergence of virtual markets with four primary distinct characteristics: real-time, shared, open, and global. Nigeria's online worth was put at about N200 billion in 2014 with huge potentials for growth.

As a continuation of the project, "Cashless policy," which commenced first in Lagos the Central Bank of Nigeria (CBN) extended its cashless policy to FCT, Kano, Anambra, Abia, Rivers, and Ogun states beginning from end of 2013 and is expected to cover the whole country in few years. The CBN continued its 
nationwide sensitization campaign on the Cashless Policy, aimed at encouraging members of the public to adopt alternative means of payment in their daily transactions. The campaign covered 30 states of the Federation, which were not yet under the policy. The policy was being implemented in some States, namely Abia, Anambra, Kano, Lagos, Ogun, and Rivers and the FCT. Given the success recorded by the policy in Lagos and the adaptation of Lagos bank customers to alternative transaction media, the implementation of the policy in other parts of the country will aid online shopping in the country. The Internet is considered a mass medium that provides the consumer with purchase characteristics as no other medium.

Online shopping also has some challenges especially in Nigeria. Rosenberg [46] avers that anybody or organization building e-commerce platform in Nigeria need to know the following:

Payment methods and cash-on-delivery: despite attempts to reduce Nigeria's reliance on cash, the economy is still very much cash-based as credit card penetration remains limited. Allow customers to pay cash on delivery alongside other payment methods.

Human contact: Nigerians value human interaction when shopping. They like to touch, feel, and speak about the product. Have customer relations managers call customers after the item has been reserved online to make sure the customer really wants the product. Allow customers to touch and see the product on delivery.

Online deals: offer good online deals to highlight the appeal of online shopping and build recurring customers as Nigerians are very price sensitive and will compare prices.

Trust: Nigerians are very suspicious of buying online considering high levels of cybercrime. Once trust is established through the steps outlined above, customers will shop online for your products with fewer reservations.

Challenges: Nigeria's e-commerce industry faces various challenges including poor infrastructure, road congestions, power blackouts, the high cost of Internet, and cybercrime.

Poor to inadequate infrastructure is a major issue affecting online/Internet activities in Nigeria. [47] reports that Nigeria belong to the middle electronic government development index (EGDI) which ranges from 0.25 to 0.50 for the year under review. Nigeria has a EGDI of 0.3807 for 2018, which is very low. Despite this low ranking, however, Nigeria's ranking in the online service component of the EGDI is much higher at 0.5278. This is a clear indication that, despite the poor telecommunications infrastructure, Nigerians are keying into online shopping as a phenomenon in modern day transactions. The UN-EGDI reports that Nigeria has a telecommunications infrastructure index (TII) of 0.1881 ; wireless broadband is 23.27 per 100 inhabitants while fixed broadband is put at 0.06 per 100 inhabitants. Hence, utilizing online to pay for items like school fees through the Remita platform is always hectic and can take days to accomplish. This calls for serious investment in the telecommunications infrastructure to address the deficit and bring about enhanced online operations in Nigeria.

\section{Conclusion}

Customer satisfaction relates to a customer's feelings of pleasure or disappointment from consuming a product or service and comparing perceived outcome to expectations. Where the experience falls short of expectations, the customer is dissatisfied. If the consumption meets the customer's expectations, the customer is satisfied. If it exceeds expectations, the customer is highly satisfied or delighted. The development of information and communication technology (ICT) and its 
wide application in marketing led to the development of online retailing where customers now shop from the convenience of their homes and or offices. This has redefined customer satisfaction as customers can go online to read and learn product reviews before making purchases. With the emergence of social media, customer engagement is rife and can create value for the firm. The relationships that exist between customer satisfaction and customer loyalty are premised on the kind of product categorization, absence or presence of moderating factor(s), the circumstances, and the market type and competition. Several models have been employed in studying customer satisfaction with online retailing have used in consumer satisfaction studies. These include: the disconfirmation of expectations model; perceived performance model; rational expectations model; expectations-artifact model; attribution model; cognitive dissonance model; comparison level model; contrast model; and the Kano model. There is the need for a holistic/multidimensional approach to engagement as a way of enhancing engagement in the present information, communication and technology (ICT) driven age.

Information technology (IT) companies have been inclined to use the term customer relationship management (CRM) to describe the software applications that automate the marketing, selling, and service functions of businesses [48]. Hence, CRM became synonymous with technology. Many organizations especially those with large customer base like banks and online retailers can employ information technology tools to help them customer relationship management (CRM). Data mining techniques can be used to identify which customers are likely to defect, what can be done to win them back, which customers are hot prospects for cross-sell offers, and how best to communicate those offers. Banks want to win a greater share of customer spend (share of wallet) on financial services. In terms of operational CRM, many banks have been transferring service into contact centers and online in an effort to reduce costs, in the face of considerable resistance from some customer segments. IT-enabled purchasing processes can deliver higher levels of accuracy in stock replenishment. Manufacturers can run CRM-enabled marketing campaigns which are highly cost effective. Consumer goods manufacturers deal with the retail trade. They use CRM to help them develop profitable relationships with retailers. Through an extensive use of IT, banks are using virtual banking to provide services without any requirement for the physical walk-in-premises. Apart from the common forms of virtual banking like ATMs, electronic fund transfer, magnetic ink character recognition (MICR), a bank like United Bank for Africa (UBA) are using an artificial human called Leo, the Virtual Banker, to reach customers and access customers who can chart with the virtual banker on any bank product or service. Also the Nigeria Access Bank Mobile has in-built mechanism that once you transact on mobile there is a question for the customer to report any issue with the transaction. Accordingly, CRM helps organizations understand costs-to-serve, issues with using a particular product/service and customer profitability by deploying relevant IT solutions like artificial intelligence (AI). AI can be a great solution for to deal with complex data over time and interact between different customer behaviors that can be difficult for people to handle. AI can also look at a variety of data, including new sources and interactions between behaviors to determine risk and by so doing organizations can use AI analyses to recommend likely better offer that can most likely retain a valuable customer. Hence, key account management practices are applied to strategically significant customers or customer segments.

Conclusively, CRM activities in modern companies are easily enhanced effectively and efficiently with the application IT tools and methods. Since CRM involves planning, organizing, directing, and coordinating actual and potential customers of an organization, the use of IT tools to generate and manage big data like spread sheet, machine learning, and artificial intelligence will help improve customer data 
mining. IT tools and methods are veritable instruments in achieving robust and comprehensive CRM especially in the twenty-first century where customers generate enormous data that are essential to decision making. CRM software enables organizations to handle and coordinate their service-related inbound and outbound communications across all channels. This can enhance effectiveness and efficiency through service cost reductions, improvement service quality, lifting productivity, and increasing customer satisfaction.

\section{Author details}

Titus Okeke

Nnamdi Azikiwe University, Awka, Nigeria

*Address all correspondence to: tc.okeke@gmail.com

\section{IntechOpen}

(C) 2019 The Author(s). Licensee IntechOpen. This chapter is distributed under the terms of the Creative Commons Attribution License (http://creativecommons.org/licenses/ by/3.0), which permits unrestricted use, distribution, and reproduction in any medium, provided the original work is properly cited. (cc) BY 


\section{References}

[1] Oluwanisola S. Customer Satisfaction. 2009. Retrieved from: https:EzineArticles.expert/ oluwanisola-seun/352487

[2] Kumar V, Arif T, Singh S. Role of ICT in driving e-commerce business in developing countries. In: National Conference on Recent Innovations \& Advancements in Information Technology. 2014

[3] Srivastava N, Singh S. E-business: Scope and challenges in India. International Journal of Business and Management Invention. 2013;2(8):1-8

[4] Paola TP. Customer satisfaction: Modelling for mobile data services [MSc thesis]. Department of Management Technology, The Delft University of Technology; 2013

[5] Fleming E. How to Maintain Customer Satisfaction. 2010. Retrieved from: https://EzineArticles.com/expert/ Rachel Fleming/805438

[6] Evans MB. Customer satisfactionwhy it is important and how to improve it. 2009. Retrieved from: https://EzineArticles.com/expert/ melisa-B-Evans/320458

[7] Safi FOD. The relationship between customer satisfaction and customer loyalty: Emotional brand image as a moderating variable-an applied study on (Airtel) for telecom services in India. International Journal of Scientific and Research Publications. 2017;7(6):64-71

[8] Bae YH. Three essays on customer satisfaction customer loyalty association [doctoral thesis]. University of Iowa; 2012

[9] Kumar VS. The relationship between customer satisfaction and customer loyalty in the commercial vehicle industry in India. International Journal of Management and International Business Studies. 2018;8(1):11-22

[10] Al- Msallam S. The relationship between customer satisfaction and customer loyalty in the banking sector in Syra. Journal of Marketing and Consumer Research. 2015;7:27-34

[11] Khadka K, Maharjan S. Customer satisfaction and consumer loyalty [business management thesis]. Pietarsaari: Centria University of Applied Sciences; 2017

[12] Okeke TC, Ezeh GA, Nnedum OAU. Service quality dimensions and customer satisfaction with online services of Nigerian banks. Journal of Internet Banking and Commerce. 2015;20:116. DOI: 10.4172/2165-7866.1000117

[13] Gunning JG. Models of customer satisfaction and service quality as research instruments in construction management. In: Akintoye A, editor. 16th Annual ARCOM Conference, 6-8 September 2000. Vol. 1. Glasgow Caledonian University, Association of Researchers in Construction Management. UK: ARCOM; 2000. pp. 21-30

[14] Anderson RE. What is Customer Satisfaction and Why is it Important? 2010. Retrieved from: https:// EzineArticles.com/expert/Rose-Elsa Anderson/725116

[15] Barsky JD. Customer satisfaction in the hotel industry meaning and measurement. Hospitality Research Journal. 1992;16:51-73

[16] Barsky JD, Labagh R. A strategy for customer satisfaction. The Cornell Hotel and Restaurant Administration Quarterly. 1992;10:32-40

[17] Pizam A, Milman A. Predicting satisfaction among first-time 
visitors to a destination by using the disconfirmation of expectation theory. International Journal of Hospitality Management. 1993;12:197-209

[18] Tribe J, Snath T. From SERVQUAL to HOLSAT: Holiday satisfaction in Varadero, Cuba. Tourism Management. 1998;19:125-134

[19] Weber K. Assessment of tourist satisfaction, using the disconfirmation of expectations theory. A study of the German travel market in Australia. Pacific Tourism Review. 1997;1:35-45

[20] Bearden WO, Teel EJ. Selected determinates of consumer satisfaction and complaint report. Journal of Marketing Research. 1983;20:21-28

[21] Cardotte ER, Woodruff RB, Jenjins RJ. Expectations and norms in models of consumer satisfaction. Journal of Marketing Research. 1987;24:305-314

[22] Swan JE, Martin S. Testing the comparison level is a predictive expectation model of satisfaction. In: Kenth B, editor. Advances in Consumer Research. Ann Arbor: MI Association of Consumer Research; 1981. pp. 77-82

[23] Oliver RL, Swan EJ. Consumer perceptions of interpersonal equity and satisfaction in transactions. A field survey approach. Journal of Marketing. 1989;53:21-35

[24] Oliver RL, Desarbo WS. Response determinant in satisfaction judgment. Journal of Consumer Research. 1988;14:495-507

[25] Poele W. The rational expectation in the macro model. Brookings Papers on Economic Activity. 1976;2:463-514

[26] Grossman SJ. An introduction to the theory of rational expectations under asymmetric information. Review of Economic Studies. 1981;48:541-559
[27] Tardi C. Rational Expectation Theory. 2019. Retrieved from: https:// www.investopedia.com/terms/r/ rationaltheoryofexpecations.asp

[28] Weiner B, Frieze I, Kukla A, Reed L. Perceiving the Causes, Success, and Failure. Morristown, New Jersey: General Learning Press; 1971

[29] Yuksel A, Yulsel F. Customer Satisfaction Theories: A Critical Review. In Tourist Satisfaction and Complaining Behavior: Measurement, and Management Issues in the Tourism and Hospitality Industry. New York: Nova Science Publishers; 2008

[30] Thibaut JW, Kelly KH. The Social Psychology of Groups. New York: John Wiley \& Sons Inc.; 1959

[31] Hovland CI, Harvey OJ, Sherif M. Assimilations and contrast effects in reaction to communication and attitude change. Journal of Abnormal and Social Psychology. 1957;55(7):244-252

[32] Prasad SS. Kano Model of Customer Satisfaction and its Importance. International School of Management Excellence Blog. 2019. Retrieved from: https://www.isme.in/kano-madelof-customer-satisfaction-and-itsimprtance.html

[33] Baki B, Basfirinci CS, Cilingir Z, Murat AR. An application of integrating SERVQUAL and Kano's model into QFD for logistics services: A case study from Turkey. Asia Pacific Journal of Marketing and Logistics. 2009;21(1):106-126

[34] Chen M, Chang K, Hsu C, Yang I. Understanding the relationship between service convenience and customer satisfaction in home delivery by Kano model. Asia Pacific Journal of Marketing and Logistics. 2010;23(3):386-410. DOI: $10.1108 / 13555851111143277$ 
[35] Brarret A. Understanding Customer Engagement. 2012. Retrieved from: https://EzineArticles.com/ expert/A-Barret/1422815

[36] Feather K. Defining Customer Engagement. 2011. Retrieved from: https://EzineArticles.com/expert/ Kate-Feathers/338455

[37] McLean G. Examining the determinants and outcomes of mobile app engagement, a longitudinal perspective. Computers in Human Behaviour. 2018;84:392-403

[38] Ibrahim NF, Wang X, Bourne H. Exploring the effect of user engagement in online brand communities: Evidence from twitter. Computers in Human Behaviour. Bristol-UK: Research and Enterprise Development, University of Bristol; 2017;72:321-338

[39] Hepola J, Karjaluoto H, Shaikh AA. Consumer engagements and behavioural intentions towards the continuous use of innovative mobile banking applications, case study of Finland. In: International Conference on Information Systems (ICIS-2016), Dublin, Ireland, December, 11-14, 2016

[40] Dessart L, Veloutsou C, Morgan-ThomasA.Consumerengagement in online brand communities: A social media perspective. Journal of Product and Brand Management. 2015;24(1):28-42

[41] Kotler P, Keller KL. Marketing Management. 15th ed. Essex: Pearson Education Limited; 2016

[42] Pansari A, Kumar V. Customer engagement: The construct, antecedents, and consequences. Journal of the Academy of Marketing Science. 2017;45(3):294-311

[43] Bisht K. The Rise of Technology in Customer Engagement. 2015. Retrieved from: https://EzineArticles.com/expert/ Kiran-Bisht/2139376

[44] Central Bank of Nigeria (CBN). Guidelines on Electronic Banking in Nigeria August. Abuja, Nigeria: CBN Publications; 2003. Accessed from: www.cenbankng.com.

[45] Internet World Stats. Africa Internet Usage and Population Stats [Online]. 2019. http://www.internetworldstats. com/europa.html.uk [Accessed: 27 July 2019]

[46] Rosenberg A. Adapt to Nigeria's Changing Business Environment. Frontier Strategy Consulting Group. Lagos, Nigeria. Online Document; 2013. Available from: https://www. howwemadeitinafrica.com

[47] United Nations. E-Government Survey. New York: Department of Economic and Social Affairs, United Nations; 2018. Online Edition.

Publicadministration.un.org. [Accessed 28 July 2019]

[48] Buttle F. Customer Relationship Management: Concepts and Technologies. Oxford, UK: Elsevier Limited; 2009 



\title{
Qualitative Analysis of Different CRM Evaluation Models
}

\author{
Christoph Weiss, Johannes Keckeis and Manfred Kofler
}

\begin{abstract}
Customer relationship management (CRM) systems help companies to manage their business processes. Specially for sales, campaigns, contact management, etc. The simpler and more efficient the business processes are executed, the more profitable these companies can be. Therefore, the process of selecting and evaluating a CRM system is an important success factor for each company in every industry and in every company size. The qualitative analysis of CRM evaluation models examines the necessary phases and activities for selecting a new CRM system. It is important to go through the relevant phases in the selection in order to be able to make a decision in a structured manner.
\end{abstract}

Keywords: analyze, business management, CRM, customer relationship management, criteria, decision, evaluation, evaluation models, normalize, market information, model, negotiation, project, requirements, selection, solution, system

\section{Introduction}

A customer relationship management (CRM) system is a business management software [1]. CRM software solutions usually include relevant modules for managing and executing business processes in a company such as operational CRM processes (marketing processes, sales processes, or service processes), analytical CRM processes (target group analysis, cross-selling analysis, or customer risk analysis), comprehensive processes (customer value analysis, customer segmentation, or customer characterization), or strategic processes (strategic analysis, strategic conception, or strategic controlling) [2]. A CRM system helps various parts of sales and marketing departments of an organization to organize and share data and knowledge, reduce costs, and improve the management of their business processes [3].

Various architectures of CRM systems exist on the market: proprietary CRM systems, modules as a part of ERP systems, and original equipment manufacturer (OEM) systems in enterprise system landscapes. CRM vendors and implementation partners offer similar bundles of functionalities in their software-products: a set of application modules that fit together. Each module includes a variety of functions [3].

There are different approaches for evaluating and implementing a CRM system. Thus, software evaluation is not a simple technical activity; it is a decision process including subjectivity and uncertainty with no possibility of arbitrary reduction [4]. As listed in the Appendix, several authors developed evaluation models with different methods between 1998 and 2017. These models are structured in different phase sequences and are used as a base for this paper. 


\section{Methodology}

The methodology approach is structured in two phases:

\section{Literature analysis}

2. Qualitative content analysis (word analysis)

In the first phase (literature analysis), different models in evaluating CRM systems are identified and used as a basis to develop a new CRM evaluation model. Twentyone different CRM evaluation models have been identified (see Appendix: Table 16).

In the second phase, all identified papers are processed via a qualitative content analysis (word analysis). In this analysis, sources, levels, phases, activities, and tasks are qualitatively coded. Identical or similar phrases are combined and derived [5] as shown in Table 1.

\begin{tabular}{lcccc}
\hline Source & Level & Phase & Original wording & Activity \\
\hline Q029E01001 & E01 & Requirements & $\begin{array}{c}\text { Defining requirements: first } \\
\text { requirements and then software }\end{array}$ & Define requirements \\
\hline Q253E01002 & E01 & Requirements & Definition of requirement & Define requirements \\
\hline Q139E02012 & E01 & Requirements & Develop CRM request matrix & Define requirements \\
\hline
\end{tabular}

Table 1.

Example of word analysis.

Within the word analysis, terms are summarized as shown in the following examples [6]:

- “analyze” (analyze, check, identify, verify, ... )

- “define" (appoint, define, form, setup, organize, ... )

\subsection{Different ways of sequencing}

Based on the word analysis, the sequences of phases and activities are determined. Three different calculation types are used to determine the sequences:

1. The phases or activities were normalized in each evaluation model, and an average value was calculated.

2. Average value is given by the sum of the multiplication of nominations per phase/activity number, and the frequency of the mentions in this phase/ activity is divided by the amount of nominations per phase/activities.

3. The mean is determined from the occurrence of the identified first and last phase or activities of the analyzed models.

$\begin{array}{llllllll}\text { Phase/activity } & \text { Nomination in phase/activity } & \sum & \text { A } & \text { B } & \text { C } & \text { D }\end{array}$

$\sum$ : number of entries in the 21 papers.

A: average of phase/activity numbers (phases including nominations). 
B: sum of (amount of nominations per phase * phase number)/amount of nominations per phase/activity.

C: normalized phase/activity (see normalization formula in the appendix:

Table 17).

D: ranking (column C).

\section{Analysis}

The number of phases within the different CRM evaluation models varies between two and eight phases. In this analysis, only phases which are listed in minimum three of the 21 papers mentioned before were considered. On average 4,48 phases are present. Table 2 shows the considered phases.

\begin{tabular}{lcccccc}
\hline Phase & Nomination in phase & S & A & B & C & D \\
\hline (Business)process analysis & 1,4 & 3 & 2.5000 & 2.0000 & 0.1429 & 3 \\
\hline Analyze & $1,2,3,7$ & 9 & 4.0000 & 2.4444 & 0.2974 & 5 \\
\hline Conditions & 1 & 3 & 1.0000 & 1.0000 & 0.0000 & 1 \\
\hline Decision & $3,4,5,8$ & 7 & 5.5000 & 5.2857 & 1.0000 & 13 \\
\hline Evaluation & 2,4 & 3 & 3.0000 & 3.3333 & 0.6667 & 8 \\
\hline Longlist & 2,3 & 4 & 2.5000 & 2.5000 & 0.3571 & 7 \\
\hline Market information & $1,2,3,4,5$ & 6 & 3.0000 & 2.6667 & 0.3262 & 6 \\
\hline Negotiation and contract & $3,5,7$ & 3 & 5.0000 & 5.0000 & 0.9524 & 12 \\
\hline Presentation & $3,4,7$ & 10 & 5.0000 & 4.2000 & 0.6888 & 10 \\
\hline Project initialization & 1,2 & 5 & 1.5000 & 1.2000 & 0.0286 & 2 \\
\hline Requirement definition & $1,2,3$ & 11 & 2.0000 & 1.8182 & 0.2576 & 4 \\
\hline Selection & $1,2,3,4,5,6,8$ & 22 & 4.5000 & 3.3182 & 0.6683 & 9 \\
\hline Shortlist & $3,4,5$ & 4 & 4.0000 & 4.0000 & 0.7667 & 11 \\
\hline
\end{tabular}

Table 2.

Considered phases.

The following terms are mentioned in the papers on the one hand as an activity in a selection phase and on the other hand as a phase: definition of requirements, longlist, market information, presentation, negotiation and contract, and decision.

Each phase is structured with different activities. In this analysis, only activities which are listed at least two times in the phases mentioned before are considered. In the 21 papers, these activities are called sub-phases or detail descriptions. Further identified and analyzed activities will be added after each phase.

\subsection{P1 condition phase}

The main activity in the first phase is clarification and definition of the strategy. This concerns the corporate strategy as well as the IT strategy and CRM strategy (Table 3).

\begin{tabular}{lcccccc}
\hline Activities & Nomination in phase & $\sum$ & A & B & C & D \\
\hline Define strategy & 1 & 2 & 1.0000 & 1.0000 & 0.0000 & 1 \\
\hline
\end{tabular}

Table 3.

Activities in the condition phase. 


\subsubsection{Other activities}

It is important to differentiate the CRM evaluation project from other projects in the company and to focus on the selection and implementation of CRM processes with a new CRM system. Furthermore, basic requirements are clarified.

\section{2 $\mathrm{P} 2$ project initialization phase}

In Table 4, four activities are identified. At the beginning of the project initiation, a project manager is appointed by the management. The project manager defines the project and elaborates the project assignment in detail. One focus is detailing the goals, which have been defined by the management in the condition phase. Following this, the project will be launched.

\begin{tabular}{lcccccc}
\hline Activities & Nomination in phase & $\sum$ & A & B & C & D \\
\hline Define a project & 1,4 & 3 & 2.5000 & 3.0000 & 0.4000 & 4 \\
\hline Define goals & 1,3 & 2 & 2.0000 & 2.0000 & 0.2000 & 3 \\
\hline Define project manager & 1 & 2 & 1.0000 & 1.0000 & 0.0000 & 1 \\
\hline Start project & 1,2 & 2 & 1.5000 & 1.5000 & 0.0714 & 2 \\
\hline
\end{tabular}

Table 4 .

Activities in the project initialization phase.

\subsubsection{Other activities}

A project sponsor is set by the management to give the project the necessary importance in the company. The project is justified by the project manager who defines the project team. The detailed project scope is agreed with the project team and the project client. Another activity includes conducting a preliminary study on the feasibility of the CRM project. A kickoff is prepared and carried out. A detailed risk analysis is done and a risk management for the project is established. On the one hand the project budget is defined and on the other hand a exact timetable is defined and formulated.

\subsection{P3 (business) process analysis phase}

In the process analysis phase, all necessary business processes are defined. This phase includes identification, documentation, and evaluation of all CRM processes. In further step criteria for the evaluation of CRM systems, CRM providers and CRM business processes are defined (Table 5).

\begin{tabular}{lcccccc}
\hline Activities & Nomination in phase & $\sum$ & A & B & C & D \\
\hline Develop processes & 1,4 & 2 & 2.5000 & 2.5000 & 0.2143 & 2 \\
\hline Set criteria & 1,2 & 2 & 1.5000 & 1.5000 & 0.5000 & 1 \\
\hline
\end{tabular}

Table 5 .

Activities in the project initialization phase.

\subsubsection{Other activities}

In business process analysis, processes can be further developed and modeled. 


\section{4 $\mathrm{P} 4$ requirement definition phase}

In the requirement definition phase, the requirements (business and technical view) are determined, analyzed, defined, and prioritized. Specifications are developed for detailed requirements. These requirements affect the CRM processes, CRM systems, and CRM providers. The detailed requirements are listed in a requirement catalog, which is the basis for the specifications (Table 6).

\begin{tabular}{lcccccc}
\hline Activities & Nomination in phase & $\sum$ & A & B & C & D \\
\hline Analyze requirements & 1 & 2 & 1.0000 & 1.0000 & 0.0000 & 1 \\
\hline Create requirement catalog & $1,2,5$ & 3 & 3.0000 & 2.6667 & 0.4444 & 5 \\
\hline Create specifications & 4,5 & 2 & 4.5000 & 4.5000 & 0.7143 & 6 \\
\hline Define requirements & $1,2,3$ & 17 & 2.0000 & 1.5294 & 0.1863 & 4 \\
\hline Determine requirements & 1,2 & 4 & 1.5000 & 1.2500 & 0.0000 & 1 \\
\hline Prioritize requirements & 1 & 2 & 1.0000 & 1.0000 & 0.0000 & 1 \\
\hline Set criteria & 3,4 & 3 & 3.5000 & 3.3333 & 0.9167 & 7 \\
\hline
\end{tabular}

Table 6.

Activities in the requirement definition phase.

\subsubsection{Other activities}

Selection criteria are weighted, and the decision criteria are prioritized. CRM processes are developed. Target processes for the processing of CRM activities are defined.

\subsection{P5 analysis phase}

An actual analysis of all relevant CRM business processes must be carried and worked out. This includes all needs for functions and processes of the CRM systems. Furthermore, the future (CRM) processes will be developed, and the selection criteria will be evaluated (Table 7).

\begin{tabular}{lcccccc}
\hline Activities & Nomination in phase & $\sum$ & A & B & C & D \\
\hline Analysis needs & 2 & 2 & 2.0000 & 2.0000 & 0.2500 & 2 \\
\hline Evaluate criteria & 2,3 & 4 & 2.5000 & 2.2500 & 0.4167 & 4 \\
\hline Capture software & 2 & 2 & 2.0000 & 2.0000 & 0.3330 & 3 \\
\hline Develop processes & 2,3 & 2 & 2.5000 & 2.5000 & 0.4167 & 4 \\
\hline Perform an actual analysis & $1,2,3$ & 4 & 2.0000 & 1.7500 & 0.1214 & 1 \\
\hline Perform analysis & 2,7 & 2 & 4.0000 & 4.5000 & 0.6786 & 6 \\
\hline
\end{tabular}

Table 7.

Activities in the analysis phase.

\subsubsection{Other activities}

The following points are defined:

- All necessary (CRM) processes evaluation criteria 
- Quantity structure such as number of offers, customers, etc.

- IT infrastructure

- CRM improvement potentials

\subsection{P6 market information phase}

Within the market information phase, not only CRM systems but also CRM vendors and CRM implementation partners are determined and structured in an adequate market overview (Table 8).

\begin{tabular}{lcccccc}
\hline Activities & Nomination in phase & $\sum$ & A & B & C & D \\
\hline Conduct market research & $3,4,5$ & 3 & 4.0000 & 4.0000 & 0.4857 & 3 \\
\hline Market overview & 1,2 & 2 & 1.5000 & 1.5000 & 0.2500 & 2 \\
\hline Search providers & 1 & 2 & 1.0000 & 1.0000 & 0.0000 & 1 \\
\hline
\end{tabular}

Table 8.

Activities in the market information phase.

\subsubsection{Other activities}

In P6, a first longlist is created. This is done based on the evaluation of the market data. Detailed information is collected from the providers in the form of a specification.

\subsection{P7 longlist phase}

\subsubsection{Other activities}

A longlist of CRM systems and CRM provider (vendor and implementation partner) is created (Table 9). All possible CRM systems and CRM providers are listed. Based on the defined criteria, the CRM systems and CRM providers are evaluated.

\begin{tabular}{lcccccc}
\hline Activities & Nomination in phase & $\sum$ & A & B & C & D \\
\hline Create longlist & 2,3 & 3 & 2.5000 & 2.3333 & 0.3810 & 1 \\
\hline
\end{tabular}

Table 9.

Activities in the longlist phase.

\subsection{P8 evaluation phase}

\subsubsection{Other activities}

In addition to the (CRM) business processes (Table 10), the IT infrastructure is also evaluated.

\begin{tabular}{lcccccc}
\hline Activities & Nomination in phase & $\sum$ & A & B & C & D \\
\hline Evaluate criteria & 2,4 & 2 & 3.0000 & 3.0000 & 0.6250 & 1 \\
\hline
\end{tabular}

Table 10.

Activities in the evaluation phase. 


\subsection{P9 selection phase}

The selection can be done over 1-n stages (basic selection or preselection, fine selection, and final selection). Depending on size and/or complexity of the evaluation, all three or even two sub-phases can be necessary (Figure 1).

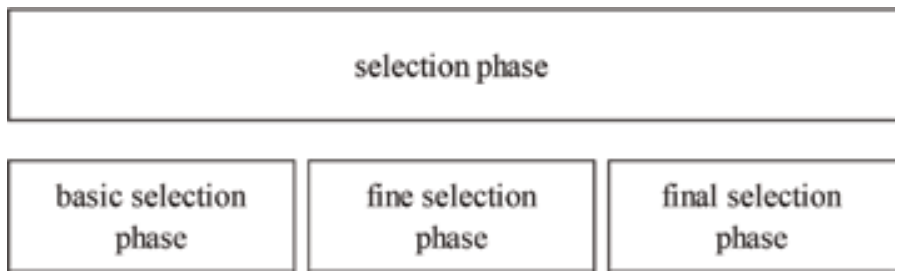

Figure 1.

Selection phases.

The proposals from the selection phase are compared and evaluated according to predefined criteria. Presentations and workshops will be held for the decisionmaking of CRM software and CRM providers. An implementation plan is created (Table 11).

\begin{tabular}{lcccccc}
\hline Activities & Nomination in phase & E & A & B & C & D \\
\hline Compare offers & $3,4,5$ & 4 & 4.0000 & 3.0000 & 0.5333 & 6 \\
\hline Create implementation plan & 4,5 & 2 & 4.5000 & 4.5000 & 1.0000 & 12 \\
\hline Evaluate criteria & $1,2,4$ & 5 & 2.5000 & 1.8000 & 0.5000 & 5 \\
\hline Make decision & $3,5,7$ & 4 & 5.0000 & 5.5000 & 0.9643 & 11 \\
\hline Make rough selection & $1,4,5$ & 3 & 3.0000 & 3.3333 & 0.4095 & 4 \\
\hline Make selection & $1,2,3,4,6,8$ & 10 & 4.5000 & 3.4000 & 0.8167 & 10 \\
\hline Perform fine selection & $2,4,6$ & 4 & 4.0000 & 3.5000 & 0.7381 & 8 \\
\hline Perform preselection & $1,2,5,6$ & 9 & 3.5000 & 2.5556 & 0.2170 & 3 \\
\hline Perform presentations & 2,4 & 3 & 3.0000 & 2.0000 & 0.1667 & 2 \\
\hline Perform workshops & 3,6 & 2 & 4.5000 & 4.5000 & 0.6500 & 7 \\
\hline Select software & $2,3,4$ & 3 & 3.0000 & 3.0000 & 0.8056 & 9 \\
\hline Tender & $1,3,6$ & 3 & 3.5000 & 3.3333 & 0.1000 & 1 \\
\hline Perform final selection & 6,8 & 2 & 7.0000 & 7.0000 & 1.0000 & 12 \\
\hline
\end{tabular}

Table 11.

Activities in the selection phase.

\subsubsection{Other activities}

In the selection phase, it may be necessary to carry out market research again. Possible first tests of CRM systems are completed. Visits to reference customers of the CRM providers are prepared and carried out. For this, questions are prepared, and potential participants are determined. CRM business cases are defined. Possible CRM providers are contacted and the answered specifications pre-evaluated.

Contract negotiation contracts are drafted, and initial negotiations are carried out. Detailed requirements are determined, the essential selection criteria are defined, and, if necessary, the criteria are weighted. 


\subsection{P10 presentation phase}

During P10 phase, 1-n presentations will be held. This can also be considered as a proof of concept (Table 12).

\begin{tabular}{lcccccc}
\hline Activities & Nomination in phase & $\sum$ & A & B & C & D \\
\hline Perform presentations & $3,4,7$ & 8 & 4.2500 & 8 & 0.6824 & 1 \\
\hline Proof of concept & 4 & 2 & 4.0000 & 2 & 0.7143 & 2 \\
\hline
\end{tabular}

Table 12.

Activities in the presentation phase.

\subsubsection{Other activities}

An agenda must be created for vendor presentations. The vendor presentations should be moderated. A documentation (e.g., minutes) of each vendor presentation is created. Each vendor presentation is rated by a defined Team via defined questionnaire. For the vendor presentations, data for the prototype is provided. The activities for the vendor presentations are also valid for the proof of concept.

\subsection{P11 shortlist phase}

\subsubsection{Other activities}

A shortlist of CRM systems and CRM providers (vendors and implementation partners) must be created (Table 13). All CRM systems and CRM providers from the reduced longlist are collected in the list. Based on previous defined detailed criteria, the CRM systems and CRM providers are evaluated and reduced to a shortlist.

\begin{tabular}{lcccccc}
\hline Activities & Nomination in phase & $\sum$ & A & B & C & D \\
\hline Create shortlist & $3,4,5$ & 4 & 4.0000 & 4.0000 & 0.7667 & 1 \\
\hline
\end{tabular}

Table 13.

Activities in the shortlist phase.

\subsection{P12 negotiation and contract phase}

The focus in this phase is to design the contracts (project contract, software contract, maintenance contract) and conduct contract negotiations (Table 14).

\begin{tabular}{lcccccc}
\hline Activities & Nomination in phase & $\sum$ & A & B & C & D \\
\hline Carry out negotiations & 3,7 & 2 & 5.0000 & 5.0000 & 0.9286 & 1 \\
\hline
\end{tabular}

Table 14.

Activities in the project initialization phase.

\subsubsection{Other activities}

The negotiation strategy is defined, and the following important contract elements are identified:

- Costs for licenses, consulting, development

- Terms of payment 
- Travel expenses

- Liability

- Warranty

- Delay

- Approval conditions

- Service-Level-Agreements (SLA)

- etc.

\subsection{P13 decision phase}

In the decision phase, all decisions are collected, and a management summary is given. Final tests provide information and form the final basis for a definite decision (Table 15).

\begin{tabular}{lcccccc}
\hline Activities & Nomination in phase & $\sum$ & A & B & C & D \\
\hline Final testing & 1,2 & 2 & 1.5000 & 1.5000 & 0.1250 & 2 \\
\hline Make decision & $3,4,5,6,8$ & 8 & 5.5000 & 5.2500 & 1.0000 & 3 \\
\hline Summarize criteria & 1 & 2 & 1.0000 & 1.0000 & 0.0000 & 1 \\
\hline
\end{tabular}

Table 15.

Activities in the decision phase.

\subsubsection{Other activities}

Possible reference customers (clients) of the final vendor are identified, contacted, and visited. During reference visits, the implementation project, the industry experience of the consultants, and the ongoing support will be discussed. The final contract negotiations are carried out. In the final phase, the most suitable system and the vendor or implementation partner are selected.

\section{Conclusion}

The study is interesting since viewpoints from a literature perspective as well as from a business side have been considered. The results of the qualitative content analysis (Figure 2) offer the possibility of the individual design of a procedure model for the selection of CRM systems.

The selection model can be changed or adjusted if necessary. This applies to the analyzed phases as well as to the respective activities within the phases.

\section{Future work}

In the qualitative analysis of CRM evaluation models, 13 phases including specific activities were identified. Based on this literature review, it is planned to conduct expert interviews. On the basis of these expert interviews, a new CRM evaluation model will be defined an afterwards tested via a quantitative analysis to 
confirm the results. Based on this new model, it is planned to develop guidelines how the model can be used.

\begin{tabular}{|c|c|c|c|c|}
\hline $\begin{array}{l}\text { P1 conditions } \\
\text { phase }\end{array}$ & $\begin{array}{l}\text { P2 project } \\
\text { initialisation phase }\end{array}$ & $\begin{array}{c}\text { P3 (business)process } \\
\text { analysis phase }\end{array}$ & $\begin{array}{l}\text { P4 requirement } \\
\text { definition phase }\end{array}$ & $\begin{array}{l}\text { P5 analysis } \\
\text { phase }\end{array}$ \\
\hline $\begin{array}{c}\text { P6 market } \\
\text { information phase }\end{array}$ & $\begin{array}{l}\text { P7 longlist } \\
\text { phase }\end{array}$ & $\begin{array}{c}\text { P8 evaluation } \\
\text { phase }\end{array}$ & $\begin{array}{l}\text { P9 selection } \\
\text { phase }\end{array}$ & $\begin{array}{l}\text { P10 presentation } \\
\text { phase }\end{array}$ \\
\hline $\begin{array}{l}\text { P11 shortlist } \\
\text { phase }\end{array}$ & $\begin{array}{l}\text { P12 negotiation } \\
\text { and contract phase }\end{array}$ & $\begin{array}{l}\text { P13 decision } \\
\text { phase }\end{array}$ & & \\
\hline
\end{tabular}

Figure 2.

Thirteen-stage selection model.

\section{Appendix}

\begin{tabular}{|c|c|c|c|c|}
\hline Model name & $\begin{array}{l}\text { Number } \\
\text { phases }\end{array}$ & Model type & Procedure & Document type \\
\hline $\begin{array}{l}5 \text { step CRM software selection guide: a } \\
\text { pragmatist's guide to CRM software } \\
\text { selection [7] }\end{array}$ & 5 & Selection & Guide & Product folder \\
\hline CRM Evaluierung [8] & 3 & Evaluation & & Product folder \\
\hline CRM implementation method [9] & 5 & Selection & Processes & Conference paper \\
\hline Software selection steps [10] & 3 & Selection & Steps & Journal paper \\
\hline $\begin{array}{l}\text { Überblick über das Referenz- } \\
\text { Vorgehensmodell [11] }\end{array}$ & 8 & Selection & $\begin{array}{l}\text { Reference } \\
\text { model }\end{array}$ & Dissertation \\
\hline Phasen der Softwareauswahl [12] & 8 & Selection & Processes & Book \\
\hline Einführung eines SFA-Systems [13] & 3 & Implementation & Phases & Technical article \\
\hline Selektionsprozess CRM-System [14] & 5 & Selection & Processes & Essay \\
\hline Phasen der Softwareauswahl [15] & 3 & Selection & Phases & Technical article \\
\hline CRM-Softwareauswahl [16] & 6 & Selection & Guide & Guide \\
\hline $\begin{array}{l}\text { CRM-Auswahl in vier Schritten zum } \\
\text { richtigen System [17] }\end{array}$ & 4 & Selection & Steps & Consultation \\
\hline CRM Beratung [18] & 2 & Implementation & Stages & Consultation \\
\hline $\begin{array}{l}\text { Übersicht über das CRM- } \\
\text { Selektionsmodell [19] }\end{array}$ & 3 & Selection & Phases & Technical article \\
\hline Auswahlprozess [20] & 4 & Selection & Phases & Consultation \\
\hline $\begin{array}{l}\text { Ideale Vorgehensweise bei einer } \\
\text { Kampagnenmanagement-Auswahl } \\
\text { [21] }\end{array}$ & 8 & Selection & & Consultation \\
\hline $\begin{array}{l}\text { Methodik und Vorgehen: Best Practice } \\
\text { CRM-Entscheidungstrichter [22] }\end{array}$ & 4 & Evaluation & Steps & White paper \\
\hline $\begin{array}{l}\text { Drei Phasen (und ein Kick-Off) zur } \\
\text { Auswahl ihrer CRM-Software [23] }\end{array}$ & 4 & Selection & Phases & White paper \\
\hline
\end{tabular}


Qualitative Analysis of Different CRM Evaluation Models

DOI: $h t t p: / / d x$.doi.org/10.5772/intechopen.89776

\begin{tabular}{lcccc}
\hline Model name & $\begin{array}{c}\text { Number } \\
\text { phases }\end{array}$ & Model type & Procedure & Document type \\
\hline $\begin{array}{l}\text { Auswahl und Einführung von } \\
\text { CRM-Systemen [24] }\end{array}$ & 6 & Selection & Road map & Study \\
\hline $\begin{array}{l}\text { Evaluationsprozess für CRM-Systeme } \\
{[25]}\end{array}$ & 3 & Evaluation & Phases & Bachelor thesis \\
\hline CRM-Projekt [26] & 2 & Selection & Phases & White paper \\
\hline Vorgehensweie im Überblick [27] & 5 & Selection & Phases & Presentation slides \\
\hline
\end{tabular}

Table 16.

Overview of the evaluation models.

\begin{tabular}{|c|c|c|c|c|c|c|c|}
\hline \# of phases & Split & \# of phases & Split & \# of phases & Split & \# of phases & Split \\
\hline 1 & 0.0000 & 1 & 0.0000 & 1 & 0.0000 & 1 & 0.0000 \\
\hline \multirow[t]{4}{*}{2} & 1.0000 & 2 & 0.5000 & 2 & 0.3333 & 2 & 0.2500 \\
\hline & & 3 & 1.0000 & 3 & 0.6667 & 3 & 0.5000 \\
\hline & & & & 4 & 1.0000 & 4 & 0.7500 \\
\hline & & & & & & 5 & 1.0000 \\
\hline \# of phases & Split & \# of phases & Split & \# of phases & Split & \# of phases & Split \\
\hline 1 & 0.0000 & 1 & 0.0000 & 1 & 0.0000 & 1 & 0.0000 \\
\hline 2 & 0.2000 & 2 & 0.1667 & 2 & 0.1429 & 2 & 0.1250 \\
\hline 3 & 0.4000 & 3 & 0.3333 & 3 & 0.2857 & 3 & 0.2500 \\
\hline 4 & 0.6000 & 4 & 0.5000 & 4 & 0.4286 & 4 & 0.3750 \\
\hline 5 & 0.8000 & 5 & 0.6667 & 5 & 0.5714 & 5 & 0.5000 \\
\hline \multirow[t]{4}{*}{6} & 1.0000 & 6 & 0.8333 & 6 & 0.7143 & 6 & 0.6250 \\
\hline & & 7 & 1.0000 & 7 & 0.8571 & 7 & 0.7500 \\
\hline & & & & 8 & 1.0000 & 8 & 0.8750 \\
\hline & & & & & & 9 & 1.0000 \\
\hline
\end{tabular}

Table 17.

Normalization formula. 


\section{Author details}

Christoph Weiss ${ }^{1 *}$, Johannes Keckeis ${ }^{2}$ and Manfred Kofler ${ }^{2}$

1 Andrássy University Budapest, Budapest, Hungary

2 Department of Strategic Management, Marketing and Tourism, University of Innsbruck, Innsbruck, Austria

*Address all correspondence to: christoph.weiss@andrassyuni.eu

\section{IntechOpen}

(C) 2019 The Author(s). Licensee IntechOpen. This chapter is distributed under the terms of the Creative Commons Attribution License (http://creativecommons.org/licenses/ by/3.0), which permits unrestricted use, distribution, and reproduction in any medium, provided the original work is properly cited. (c) BY 


\section{References}

[1] Piazolo F, Paa L, Keckeis J. ITembedded strategic management. Mittelstand Kompakt-Information im Fokus. 2012;2(2):24-27

[2] Hippner H, Hubrich B, Wilde K. Grundlagen des CRM-Strategie, Geschäftsprozesse und ITUntertützung. Wiesbaden: Gabler Verlag; 2011

\section{[3] Perera H, Costa W. Analytic} hierarchy process for selection of ERP software for manufacturing companies. The Journal of Business Perspective. 2008;12(4):1-11

[4] Nikolaos P, Sotiris G, Harris D, Nikolaos V. An application of multicriteria analysis for ERP software selection in a Greek industrial company. Operational Research, An International Journal. 2005;5(3):435-458

[5] Mayring P. Qualitative Inhaltsanalyse (Grundlagen und Techniken), Beltz, 12., überarbeitete Auflage. Weinheim und Basel. 2015

[6] Weiss C, Kofler M, Friedemann R. Qualitative analysis of different ERP evaluation models. In: ERP Future 2016: Innovations in Enterprise Information Systems Management and Engineering (5th International Conference).

Hagenberg. 2016. pp. 17-25

[7] 5 Step CRM Software Selection Guide: A Pragmatist's Guide to CRM Software Selection. [Internet]. 2007. Available from: http://www.online-crm. com/landing5step.asp [Access: 16 February 2016]

[8] CRM Evaluierung. [Internet]. 2012. Available from: http://www.intense.de/ sites/default/files/dokumente/05_crm_ evaluierung.pdf [Access: 16 February 2016]

[9] Friedrich I, Sprenger J, Breitner M. Discussion and validation of a CRM system selection approach with experts. In: AMCIS 2011 Proceedings-All Submissions

[10] Colombo E, Francalanci C. Selecting CRM packages based on architectural, functional, and cost requirements: Empirical validation of a hierarchical ranking model. Requirements Engineering. 2004;9:186-203

[11] Arens T. Methodische Auswahl von CRM Software (Ein Referenz-

Vorgehensmodell zur methodengestützten Beurteilung und Auswahl von Customer Relationship Management Informationssystemen) [dissertation]. Abt. Wirtschaftsinformatik: Georg-August-Universität, Göttingen; 2003

[12] Spielberg D. Enterprise Marketing Management (Informationslogistik für das Marketing von morgen).

Wiesbaden: Springer; 2013

[13] Lossau S, Der digitale Weg zum Kunden. Diebold Management Report, Nr. 8/9, Düsseldorf, 1998

[14] Beye D. Auswahl von CRMSystemen und TechnologiepartnernKriterien, Prozesse, und Erfolgsfaktoren [Seminararbeit]. Lüneburg: Leuphana Universität Lüneburg; 2012

[15] Schwetz W. CRM Softwareauswahl mit System: Drum prüfe, wer sich ewig bindet ... Freiburg München Berlin: Rudolf Haufe Verlag; 2007. pp. 163-190

[16] CRM-Softwareauswahl: Ein Leitfaden [Internet]. 2013. Available from: http://www.softselect.de/deu/doc uments/view/188 [Access: 28 May 2016]

[17] CRM Evaluation [Internet]. Available from: http://www.advanis.ch/ de/beratung/crm-evaluation.html [Access: 28 May 2016] 
[18] CRM Beratung [Internet]. Available from: http://www.schwetz.de/crm-bera tung.html [Access: 28 May 2016]

[19] Passgenaue CRM-Lösungen finden [Internet]. Available from: http://www. absatzwirtschaft.de/passgenaue-crmloesungen-finden-2-19306/ [Access: 28 May 2016]

[20] Vorgehensmodell Toolauswahl [Internet]. 2015. Avaliable from http:// cintellic.com/Vorgehensmodell-Toola uswahl.php [Access: 28 May 2016]

[21] Praxistipps für die erfolgreiche Kampagnenmanagement-Toolauswahl [Internet]. Available from: http:// cintellic.com/Praxistipps-Kampagne nmanagement-Toolauswahl.php [Access: 28 May 2017]

[22] Bärwolff O, Panser F. CRMEvaluation (Wie finde ich die richtige Software für mein Unternehmen?). Erfurt: TecArt GmbH; 2016

[23] Rönn S. Die 3 Phasen Ihrer CRMSoftwareauswahl-Schritt für Schritt zum richtigen CRM-System (Ein Whitepaper der ec $4 u$ expert consulting ag). ec4u expert consulting ag. In: Karlsruhe. 2016

[24] Torggler M. Einsatz von CRMSystemen (Eine empirische Studie zum praktischen Einsatz von CRM-Systemen in Österreich). Wiener Neustadt: Zentrum für Business IT-Tools, Fachhochschule für Wirtschaft und Technik; 2007

[25] Zimmermann R. Customer relationship management (CRM) Systemevaluation für Mittelstands-und Großunternehmen [bachelor thesis]. Hochschule für angewandte Wissenschaften: Ernst-AbbeFachhochule Jena; 2017

[26] Auswahl \& Einführung einer CRM-Softwarelösung (Whitepaper)
[Internet]. 2013. Available from: http:// pisasales.de [Access: 17 September 2017]

[27] Kainer H, Alznauer T. Erfahrungen bei der Bewertung und Auswahl eines CRM-Anbieters. Arbeitskreis "Customer Relationship ManagementVom Konzept zum Erfolg”. Hameln: Hochschule Weserbergland; 2003 
Section 3

\section{E-consuming Behavior}





\title{
Chapter 5
}

\section{Values and e-Consumer Behavior}

\author{
Joan Morales Alcúdia and Marina Romeo Delgado
}

\begin{abstract}
e-Consumer behavior models prior attitudes to predict e-loyalty in front values or another internal factors of customers. Scientific literature relegates to a second term the importance of values in purchase online like a predictive factor of e-loyalty. The following chapter explains why values will be determinant in consumer behavior online and e-loyalty.
\end{abstract}

Keywords: consumer behavior, shopping online, utilitarian and hedonic values, e-loyalty, organizational values

\section{Introduction}

Values are concepts or beliefs about a final desirable state. Values cross-specific situations guiding the selection and evaluation of events and behaviors ordering them through a hierarchical structure [1]. In the operational definition of "values" we can distinguish three dimensions [2]:

- An ethical dimension strategic or of preferential election: in this case the value is like a conviction or a stable belief in the time that a determinate way of behavior, or an existential purpose is personal or socially preferable to his opposite way of behavior or to his contrary existential purpose. The values can be understood like strategic learnings and relatively stable in the time that allow us act orienting us to achieve ours outputs.

- An economic dimension or cost: this dimension does reference near at hand of the significance or to the importance of a thing. When we are making decisions, values are reference guides that allow us regarding people, objects or ideas. In that sense they can be considered as internal decision criteria.

- A psychological dimension: understood as in which it defines it as: "a moral quality that moves to tackle big companies and to face without big fear dangers."

Beside these dimensions of this definition [2], it is possible to explain the fragmentation and subjectivity of a concept and sense and different uses across situations [3-5]. Regarding cultural meanings, ethical, human, and morals, values are considered like general and categorical concepts that influence in individual behavior with regard to what results are desirable and not desirable in relation to surroundings and determinate people to consider besides beliefs prescribed on what is well or what is bad [6-10]. 
Literature puts of self-evident that values are the most important factor that conform the bases of a culture and affect to the training of attitudes, being considered, therefore, like a product of a culture and the base on which form individual values that drive people by the way to taking socially desirable decisions. Therefore, values are formed between people that live in a determinate generation and go transmitting them to other generations through a socialization process, being able to be considered like a concept umbrella that includes elements such as values, beliefs, and norms shared by a collectively useful for distinguishing a determinate group of people from another. Regarding meanings referred specifically to consumers, values would be consider like internal guides that head to the individuals in relation to purchase behavior like consumers [3,11-14].

\section{Values and consumer behavior}

Studies of values in consumer behavior try to establish the relations between concrete attributes of products, abstract attributes and consequences, and consumer values [15]. A second group of the studies about the values and behavior of consumer are those investigations that consider the values like an antecedent variable [16]. These investigations try to explain how values influence thoughts and motivations [17], purchase behavior [18, 19], or product elections, preferences, attitudes, or needs [20]. Finally, the third kind of studies has been using values to segment markets or to develop advertising strategies.

\subsection{Personal values and consumer behavior}

During the last decade, the study of personal values has been an object of a large attention by part of researchers. They have been multiple the disciplines as well as the approaches that have stood out the importance of the values. From sociology, going through psychology and economy, personal values in a direct or indirect way had been present in numerous studies. According to [12] there are two approaches to the study of values. The first approach treats to establish relations between the values and the consumer behavior. Like this, different authors have tried to relate values of the subject with consumption of products [21], motivations of purchase [17], retail election [22], choice of a certain kind of food [23, 24], culture [25, 26], or with consumer behavior in general $[18,19,22,27,28]$.

The second approach studies values' influence on the behavior of consumption $[1,18,20,23,25,29-33]$. The effect of the system of values in the process of decision of the consumer also has been very established in literature [8].

Personal values are principles that guide behaviors and that are strongly tied with motivations of individuals. The personal values and the perception of value would constitute the main managerial strength of the intention of purchase for products of luxury- especially in the Occident and in the east emergent markets [34]. In accordance with [22], the strength of the personal value would root in the perception of utility in relation with the image and the symbolism in association or dissociation with cultural referents and demographic partner. In relation to the consumption and the personal values, there are two orientations that have been collected through the literature: the utilitarian orientation and the hedonic orientation.

The utilitarian orientation in consumption has been described like a tendency to emphasize the perception of functional value or his future provision [22]. Traditionally, functional value has been considered the primary conductive strength in elections of consumers [22] and the more easily adopted by consumers 
with traditional lifestyles. In this sense, consumers with utilitarian values tend to have simple lifestyles, considering the consumption like necessary for the survival but without any purpose of entertainment. Consistently, they tend to be more conscious of the value and have more positive perceptions of this value in relation to the price that they have to pay.

The hedonic term recognizes different behaviors in consumers basing them in mental criteria. Mental criteria include entertainment and appearances of excitement with the experience about the product and/or service. Entertainment reflects sensory dimensions (sight, hearing, taste, and touch) of a perceived experience. Sometimes these experiences cannot be reedited in back experiences. For example, customer experience generates directly emotional excitation, evoking emotions like pleasure, envy, fury, or anger. We can observe it when somebody goes to the restaurant and does not value neither the price or the quality of the foods, being for him or her more important, the decoration of the restaurant or the musical thread.

Study of the hedonic values initiates to finals of the 1970s [35, 36] from the investigation about consumer motivations and their relationship with products symbolism [37]. Even so, it is not until years later that some studies recognize in the products the existence of symbolic values, going further to traditional utilitarian values [38]. From here the acts of consumption are based not in what the consumers think that is real but in what they wish that it was [36]. The election of a product or a mark bases frequently in the congruence of the lifestyle and the values of consumption, as well as the symbolic perception or the meaning of the product or of the mark [36, 37]. Like this, the consumers with strong hedonic values choose his products or the marks basing more in his symbolic or expressive values that in his functional values.

\subsection{Perceived values and consumer behavior}

Perceived values are an imperative strategy for organizations [39] giving to customers an upper input about organizations and adopting an important paper in all activities of marketing [40-42] of business success. In the actuality comes accepting the idea that successful companies do not deliver products in return of a gain but rather value in return of utility. The value perceived is defined like the result of the comparison by part of the consumer of the profits perceived and the sacrifices made $[43,44]$. According to this definition, we are faced with a concept of subjective nature characterized by a certain ambiguity [45]. This fact prevents a uniform interpretation according to the term. Certain confusion in the term "perceived values" creates difficulties to compare distinct empirical studies and inconsistency in the procedures of measurement of the value perceived [46]. In this way there is consensus regarding the multidimensional of the concept of value [39] accepting the existence of several factors that should explain and measure the value perceived.

Perceived value is therefore a subjective construct in several senses: it varies between customers [47], between cultures [48], and in different temporary situations [49]. This last assessment conceives the perceived value like a dynamic factor that consumer experiences before the purchase, in the moment of the purchase, in the moment of his use, and after his use. For each one of these moments, the assessment made is different [50]. Of this form, in the moment of the purchase, the attributes of the product and the price are determinants, whereas during the use and after the same, the consequences and results obtained are the most valued elements by the customer. Therefore, to understand the process by which determinate values can generate the loyalty in the consumers, it will be necessary to define more clearly their perceived value [51]. 


\subsection{Perceived values, preferences, and intentions of purchase}

The existing literature signals a perceived value like an indicator of the intention of purchase [42] relating it besides with the attitude, the preferences, the purchase behavior, and the loyalty. That is to say, the buyer wishes the function or the service that the product is susceptible to loan and not the product in himself the same [52]. The training of preferences conceives perceived value like a development of affective states that correspond with the results of evaluation and ordination of alternatives about the available purchase made only in function of his qualities and without any consideration of costs and sacrifices associated. We speak as of a process of evaluation that takes place in absence of restrictions of cost and budgetary, as if of free and free products treated [53]. However, against profits that can contribute the product, all consumers have to bear a cost. The cost is not only economic, it also includes the time of research and the risks associated to the on-line purchase for the e-consumer. Hence the cost is one of the measures with which the consumer evaluates the sum of the profits and the satisfaction associated that expects to obtain from the purchase and the consumption of the product. From this point of view, the price is not but what the consumer offers or is had to offer in return of the quality that is received or trusts to receive. The consumer estimates the expectations and the degree of profit or the advantages that expects to receive in shape of reward when purchasing a product/service from the efforts and sacrifices that necessarily will have to make when he is choosing a product/service. Perceived value affects the purchase intention of clients. This is a result between the perceived quality of the product and the corresponding sacrifice associated with obtaining it. It coincides with what usually knows like the relation of quality/price between what is expected to be received-quality and what in return is necessary to give-price. From all of the above, we can conclude that the purchase intention is the result of an evaluation process in terms of costs and benefits [53]. From here, unlike what occurs with the preferences, the intentions of purchase reveal like predictors reasonable in the final behavior of consumer.

\subsection{Perceived values and attitudes in behavior of purchase and loyalty}

The concept of attitude refers to the learnt predisposition to answer in a consistent form to an object favorable or not favorable. According to the theory of reasoned action, the attitude of the consumer influences on the behavior of the purchase of the same. According to this theory, behavior is determined by intentions and influenced by attitudes and subjective norms. The relation between attitude and behavior intentions has been widely examined and supported empirically [54]. Since the attitudes are learnt, these seem affected by the information and the experiences. The value perceived can influence the attitude of the customer. At the same time, perceived value is important because of the influences in the confidence of consumer [39].

The existing research about how values influence behavior to go shopping and the preferences is not very common. There are not too many empirical studies that demonstrate the relationship between the values and the intention of purchases or the buying behavior $[55,56]$.

\section{Values and e-consumer behavior}

\subsection{Values online}

Investigations around values online have prospered at the same time that purchase online has been common [57]. New ways of investigation have opened 
from the instant that the retailers did not comprise the reasons about why customers used this channel, how it is used, and the requests that were necessary for his use. Keeney [16] creates a series of objective and specific categories like influence factors in the intention of purchase in the Internet. Besides, it gave a definition of value associated to the trade in the Internet like "the value of the network in terms of profits and costs of both in relation to a product and his processes of research, request, and reception of the same." In accordance with [58], the value online present in the activities that offers the Internet should be generated into the following process: research, evaluation, solution of the problem, and transaction. From here that for the companies that operate through the Internet, the value was one of the key elements since it offers a competitive advantage to the companies that develop his organizational activities orienting them and focusing to his customers [58], across perceived value a key to generate to consumer satisfaction and loyalty. In e-commerce, perceived values affect the intention to adopt the channel of purchase $[59,60]$ as well as the attitude to use it and in the intention of repurchase online [61].

Pahnila and Warsta [57] had proposed a model of consumer behavior online where hedonic and utilitarian values were antecedents of purchase behavior prioritizing values in front of the attitudes and focusing their efforts in analyzing purchase behavior online. Besides the exploration of the paper of perceived values and consumer behavior in relation of e-commerce, they propose a structural model in which they hypothesize that utilitarian and hedonic values have a direct impact on the affections of e-consumers and acting like an indirect way on the behaviors of purchase in the virtual surroundings. On the other hand, they analyze the importance of the habit in e-consumers behavior relating it to his time with e-commerce. The results obtained by these authors confirm the incidence in an indirect way of hedonic and utilitarian values in affections and indirectly on the behavior in relation to the e-commerce.

In a virtual purchase, [62] proposes two dimensions of value: like an achieve component (profits that buyer obtains of the offer to the seller) and like a concede component (monetary costs and not monetary costs in which it incurs in the acquisition of the offer). In this sense, the importance of perceived value in the electronic business comes from, between other causes, the ease that offers to the consumer to compare the characteristics of products and/or services online in relation to his prices. When the perceived value is low, the customers will bend for changing to companies and will weaken his loyalty. In other words, the customers satisfied will not be faithful to a virtual establishment if they feel that they are not obtaining the greater value perceived. Approach of [62] is predominantly economic. The economic approach is the first identified approach in brand management, and several authors pointed out that the elements of the economic approach serve as a prerequisite for most planning and execution of brand management still today. Nevertheless, this approximation does not consider neither the influence that can have the individual characteristics in the perceptive process that the consumer carries out when he interacts with the virtual surroundings from their personal values. The impulsive purchase results to be a product of wishes, longings, and motivations in the unconscious level of the consumer being and conditioned by the relation of surroundings and his individual characteristics.

\subsection{Predict models of consumer behavior and values online}

Multiple predict models about values online show the incidence of utilitarian and hedonic values in a positive affection about e-shop [63] and on e-loyalty 
and the experience of purchase in e-shops [64] or their relationship with fashion marks. Hedonic and utilitarian values have been studied as market segmentation criteria, as a background of consumer satisfaction and as influencing factors in the purchase intention in the online store. Also it has verified their empirical relation with certain dimensions of the online store, with the catalogue of products, with the intention of being sponsoring, with the adoption of devices of virtual purchase, with the antecedents of the attitude and the wish of purchase to the online retail trade, with the use of Internet as a shopping channel, and with preferences of customer about shopping online. Likewise, it has linked to the hedonic personal values and utilitarian personal values with factors like flow online with intention about the use of electronic devices [60] with the gender and the perception of utility [65] and with the perception of profits to buy in virtual shops [66].

Based on the theoretical foundation some of postulates present in the cognitive theories of social psychology (theories of the attribution, theory of the cognitive dissonance and theory of the expectation-value), [67] it is possible to assume that the e-loyalty to a determinate online shop depends of the degree of adjust/unfit between personal values of consumer and organizational values perceived in the on-line shop where the consumer develops his behaviors of purchase. In this way e-loyalty can be affected in a positive or negative way in function of the degree of conflict or the existence of congruence between organizational values perceived by the consumer in the e-shop and his own personal values in each experience of purchase online. A higher degree of congruence between personal values and organizational values perceived by the consumer in e-shop can be considered by e-buyers like as a positive result to repeat their e-purchases in a certain online store. This positive result increased the probability that in the future the consumer buys another time in the same e-shop. In this regard, congruence and/or conflict between organizational values perceived and personal values could be produced during any one of the three phases that constitute purchase process (research of information, purchase, and post-purchase process) and always from the relations of interaction generated between subject and the organization in the e-shop. The apparition of relations of conflict between personal values and organizational values perceived, understanding in this case the conflict like the degree of incongruence generated in the interactive way between personal values and the perceived values across the mark in the e-shop, would affect in a negative way to the intention of purchase as to the purchase, without offering possibilities to develop any type of loyalty to a determinate business B2C by two components: like a future preferential election of the e-shop and like a repetition of purchase [67].

Morales [67], in his predicted model of e-loyalty, found a clear differentiation between categories of utilitarian and hedonic values and a strong Pearson correlation index between utilitarian personal values and utilitarian organizational values and a weak Pearson correlation index between personal hedonic values and organizational hedonic values. Results confirm, in accordance with the existent literature $[45,69]$, the coexistence of two types of personal values (utilitarian and hedonic) when the consumers develop their behaviors of on-line purchase $[68,69]$. The results obtained confirm the relationship between personal values and organizational values and the relationship between personal values and some dimensions of store online like virtual design, product assortment, aftersales service and virtual store information [67].

\section{Conclusions}

The scientific literature referred to predictive models of consumer behavior on-line has centered their efforts in treating to analyze the intention of on-line 
purchase, being scarce the studies that do reference so much to the behavior of purchase as to the e-loyalty. In all of them, one of the most studied personal factors has been attitude. Regarding values, in spite of having been a variable collected in diverse global models like explanatory elements of e-loyalty, the attention loaned to this variable by part of the researchers has been rather scarce. In spite of models [70], e-values will be considered like an explanatory element of e-purchase intention and e-loyalty online as well as attitudes. In the same way, the predictive models referred to the behavior of the on-line consumer mostly have opted for including the attitude like one of the explanatory internal factors of behavior of purchase and the on-line loyalty, to the detriment of the values. Including online values in predict models of e-behavior online will be a gain to future research for explain better the confidence deposited by consumers in this new channel.

\section{Author details}

Joan Morales Alcúdia* and Marina Romeo Delgado

University of Barcelona (UB), Barcelona, Spain

*Address all correspondence to: jmoralesal@uoc.edu

\section{IntechOpen}

(C) 2019 The Author(s). Licensee IntechOpen. This chapter is distributed under the terms of the Creative Commons Attribution License (http://creativecommons.org/licenses/ by/3.0), which permits unrestricted use, distribution, and reproduction in any medium, provided the original work is properly cited. (cc) BY 


\section{References}

[1] Schwartz SH, Bilsky W. Toward a universal psychological structure of human values. Journal of Personality and Social Psychology. 1987;53:550-562. DOI: 10.1037/0022-3514.53.3.550

[2] García S, Dolan S. Dirección por valores. Madrid: McGraw Hill; 1997

[3] Babin BJ, Darden WR, Griffin M. Work and/or fun: Measuring hedonic and utilitarian shopping value. Journal of Consumer Research. 1994;20: 644-656. DOI: 10.1086/209376

[4] Dodds W, Monroe KB, Grewal D. Effects of price, brand, and store information on buyers' product evaluations. Journal of Marketing Research. 1991;28:307-319. DOI: $10.2307 / 3172866$

[5] Lapierre J, Filiatrault P, Chebat JC. Value strategy rather than quality strategy: A case of business-to business professional services. Journal of Business Research. 1999;45:235-246

[6] Fam KS, Merrilees B. Cultural values and personal selling. International Marketing Review. 1998;15:246-256

[7] Fricker R, Schonlau M. Advantages and disadvantages of internet research surveys: Evidence tom the literature. Field Methods. 2002;14:347-367. DOI: $10.1177 / 152582202237725$

[8] Kamatura WA, Novack TP. Valuesystem segmentation: Exploring the meaning of LOV. Journal of Consumer Research. 1992;1:119-132

[9] Kozan MK, Ergin C. Third party role in conflict management in Turkish Organizations. Human Organization. 1999;58:405-415. DOI: 10.1002/ job.4030150509

[10] Schwartz SH. A theory of cultural values and some implications for work.
Applied Psychology. 1999;48:23-47. DOI: 10.1111/j.1464-0597.1999.tb00047.x

[11] Grunert SC, Scherhorn G. Consumer values in West Germany underlying dimensions and crosscultural comparison with North America. Journal of Business Research. 1990;20(2):97-107. DOI: 10.1016/0148-2963(90)90054-H

[12] Corfman KP. Comparability and comparison levels used in choices among consumer products. Journal of Marketing. 1987;28:368-374

[13] Schwartz SH. Universals in the content and structure of values: Theoretical advances and empirical tests in 20 countries. Advances in Experimental Social Pychology. 1992;25:1-65. DOI: $10.1016 /$ S0065-2601(08)60281-6

[14] Erdem O, Oumlil A, Tuncalp S. Consumer values and the importance of store attributes. International Journal of Retail \& Distribution Management. 1999;27:137-144. DOI: 10.1108/09590559910268435

[15] Sarabia FJ, De Juan MD, González AM. Valores y estilos de vida de los consumidores. Cómo entenderlos y medirlos. Madrid: Pirámide; 2009

[16] Keeney RL. The value of internet commerce to the customer. Management Science. 1999;45:533-542. DOI: 10.1287/ mnsc. 45.4 .533

[17] Wolfe DB. Targeting the mature mind. American Demographics. 1984;16:247-252

[18] Beatty SE, Kahle LR, Homer PM, Misra S. Alternative measurement approaches to consumer values: The list of values and Rokeach value survey. Psychology and Marketing. 1985;2: 181-200. DOI: 10.1002/mar.4220020305 
[19] Kahle LR. Social Values and Social Change: Adaptation to Life in America. New York: Praeger; 1983

[20] Vinson DE, Scott J, Lamont L. The role of personal values in marketing and consumer behavior. Journal of Marketing. 1977;14:44-50

[21] Kahle LR. The values of Americans: Implications for consumer adaptation. In: Pitts RE, Woodside AG, editors. Personal Values and Consumer Psychology. Massachusetts: Lexington Books; 1984. pp. 77-86

[22] Sheth JN, Newman BI, Gross BI. Why we buy what we buy: A theory of consumption values. Journal of Business Research. 1991;22:159-170. DOI: 10.1016/0148-2963(91)90050-8

[23] Homer P, Kahle L. A structural equation test of the value-attitudebehavior hierarchy. Journal of Personality and Social Psychology. 1988;54:638-646. DOI: 10.1111/j.1559-1816.2010.00681.x

[24] Grunert SC, Juhl HJ. Values, environmental attitudes, and buying of organic foods. Journal of Economic Psychology. 1995;16:39-62. DOI: 10.1016/0167-4870(94)00034-8

[25] Munson JM, McIntyre SH. Developing practical procedures for the measurement of personal values in cross-cultural marketing. Journal of Marketing Research. 1979;16:48-52. DOI: $10.1177 / 002224377 / 002224377901$ 600107

[26] McCort DJ, Malhotra NK. Culture and consumer behavior: Toward and understanding off cross-cultural consumer behavior in Internacional marketing. Journal of International Consumer Marketing. 1993;6:91-127. DOI: 10.1300/Jo46v06n02_07

[27] Scott JE, Lamont LM. Relating consumer values to consumer behavior:
A model and method for investigation. In: Greer TW, editor. Increasing Marketing Productivity and Conceptual and Methodological Foundations of Marketing, Series 35. Chicago: American Marketing Association; 1973. pp. $283-288$

[28] Howard J. Consumer Behavior in Marketing Strategy. New York: Prentice Hall; 1989

[29] Jackson RG. A preliminary bicultural study of value orientations and leisure activities. Journal of Leisure Research. 1973;5:10-22

[30] Henry WA. Cultural values do correlate with consumer behavior. Journal of Marketing Research. 1976;13:121-127. DOI: 10.2307/3150845

[31] Grube HW, Weir IL, Geztlaf S, Rokeach M. Own value system, value images and cigarette smoking. Personality and Social Psychology Bulletin. 1984;10:306-313. DOI: 10.1177/ o146167284102018

[32] Rose GM, Shoman A, Kahle LR, Batra R. Social value, conformity, and dress. Journal of Applied Social Psychology. 1984;24:1501-1519. DOI: 10.1111/j.1559-1816.1999.tb01560.x

[33] Shoham A. Flow experiences and image making: An online chatroom ethnography. Psychology and Marketing. 2004;21:855-882. DOI: 10.1002/mar.20032

[34] Shukla P. The impact of organizational efforts on consumer concerns in an online context. Information and Management. 2103;51:113-119. DOI: 10.1016/j. im.2013.11.003

[35] Hirschman EC. The consciousness of addiction: Toward a general theory of compulsive consumption. Journal of Consumer Research. 1992;10:155-179 
[36] Hirschman EC, Holbrook MB. Hedonic consumption: Emerging concepts, methods, and propositions. Journal of Marketing. 1982;46:92-101. DOI: $10.2307 / 1251707$

[37] Echeverri P, Skålén P. Co-creation and co-destruction: A practicetheory based study of interactive value formation. Marketing Theory. 2011;71:351-373. DOI: $10.1177 / 14695440508090089$

[38] Veblen T. Teoría de la clase ociosa. México: Fondo de Cultura Económica; 1974

[39] Sweeney JC, Soutar GN. Consumer perceived value: The development of a multiple item scale. Journal of Retailing. 2001;77:203-220. DOI: 10.1016/ S0022-4359(01)00041-0

[40] Day GS. Market Driven Strategy. Processes for Creating Value. 2nd ed. New York: The Free Press; 1999

[41] Holbrook MB. Consumer Research: Introspective Essays on the Study of Consumption. Thousand Oak: Sage Publications; 1995

[42] Cronin JJ, Brady MK, Hult GTM. Assessing the effects of quality, value and customer satisfaction on consumer behavioral intentions in service environments. Journal of Retailing. 2000;76:193-218. DOI: 10.1016/ S0022-4359(00)00028-2

[43] Zeithaml VA. Consumer perceptions of price, quality and value: A meansend model and synthesis of evidence. Journal of Marketing. 1988;52:2-22. DOI: $10.1177 / 002224298805200302$

[44] McDougall GHP, Levesque T. Customer satisfaction with services: Putting perceived value into the equation. Journal of Services Marketing. 2000;14:392-410. DOI: 10.1108/08876040010340937
[45] Woodruff BR. Customer value: The next source for competitive advantage. Journal of the Academy of Marketing Science. 1997;25:139-153. DOI: 10.1007/ BF02894350

[46] Gil I, Sánchez M, Berenguer G, González-Gallarza M. Encuentro de servicio, valor percibido y satisfacción del cliente en la relación entre empresas. Cuadernos de Estudios Empresariales. 2006;15:47-72

[47] Parasuraman A. Reflections on gaining competitive advantage through customer value. Journal of the Academy of Marketing Science. 1997;25:154-161. DOI: 10.1007/BF02894351

[48] Schlaegel D, Koenig M. Determinants of entrepreneurial intent: A metaanalytic test and integration of competing models. Entrepreneurship Theory and Practice. 2014;38:291-332. DOI: 10.1111/etap.12087

[49] Ravald A, Grönroos C. The value concept and relationship marketing. European Journal of Marketing. 1996;30:19-30. DOI: 10.1108/03090569610106626

[50] Woodruff RB, Gardial SF. Know Your Customer: New Approaches to Understanding Customer Value and Satisfaction. Malden: Blackwell Business; 1996

[51] Grönroos C. The perceived service quality concept a mistake? Managing Service Quality. 2001;11:150-152. DOI: 10.1108/09604520110393386

[52] Lambin JJ, Peeters R. La Gestion marketing de l'entreprise. Paris: Presses Universitaires de France; 1977

[53] Swaminathan V, LepkowskaWhite VE, Rao BP. Browsers or buyers in cyberspace? An investigation of factors influencing electronic interchange. Journal of Computer-Mediated 
Communication. 1999;5:JCMC523. DOI: 10.1111/j.1083-6101.1999.tb00335.x

[54] Kim JD, Ferrin LD, Rao HR. A trust-based consumer decision-making model in electronic commerce: The role of trust, perceived risk, and their antecedents. Decision Support Systems. 2008;44:544-564. DOI: 10.1016/j. dss.2007.07.001

[55] Kropp F. Changing values: A 2020 vision. Journal of Euromarketing. 2003;12:79-97. DOI: 10.1300/ Jo37v12n0306

[56] Germelmann CC, Groeppel-Klein A. Is specific consumer behavior influenced by terminal values or does yellow press set the tone? In: 33rd EMAC Conference. Universidad de Murcia; 2004

[57] Pahnila S, Warsta J. Online shopping viewed from a habit and value perspective. Journal of Behavior and Information Technology.

2010;29:621-632. DOI: 10.1080/0144929X.2010.501115

[58] Gonçalves HM, Lourenço TF, Silva GM. Green buying behavior and the theory of consumption values: A fuzzy-set approachJournal of. Business Research. 2016;69:1484-1491. DOI: 10.1016/j.busres.2015.10.129

[59] Sanz S, Mafé C, Aldás J. La influencia de la dependencia en el comercio electrónico B2C. Propuesta de un modelo integrador aplicado a la intención de compra futura en Internet. Cuadernos de Economía y Dirección de la Empresa. 2008;36(36):45-76

[60] Kleijnen M, Ruyter K, Wetzels M. An assessment of value creation in mobile service delivery and the moderating role of time consciousness. Journal of Retailing. 2007;83:33-46. DOI: 10.1016/j. retail.2006.10.004
[61] Chiu C-M, Chang C, Cheng H-L, Fang Y. Determinants of customer repurchase intention in online shopping. Online Information Review. 2009;33:761-784. DOI: $10.1108 / 14684520910985710$

[62] Parasuraman A, Grewal D. The impact of technology on the qualityvalue-loyalty chain: A research agenda. Journal of the Academy of Marketing Science. 2000;28:168-174. DOI: 10.1177/0092070300281015

[63] Babin BJ, Attaway J. Atmospheric affect as a tool for creating value and gaining share of customer. Journal of Business Research. 2000;49:91-99. DOI: 10.1016/S0148-2963(99)00011-9

[64] Jones MJ. Hedonic and utilitarian shopping value: Investigating differential effects on retail outcomes. Journal of Business Research. 2006, 2006;59:974-981. DOI: 10.1016/j. busres.2006.03.006

[65] Yang K, Lee H. Gender differences in using mobile data services: Utilitarian and hedonic value approaches. Journal of Research in Interactive Marketing. 2010;4:142-156

[66] Sarker S, Wells JD. Understanding mobile handheld device use and adoption. Communications of the ACM. 2003;46:35-40. DOI: $10.1145 / 953460.953484$

[67] Morales J. A predictive model of e-loyalty in BC2 [thesis]. Barcelona: Universitat de Barcelona; 2017

[68] Chiu C-M, Wang E, Fang Y, Huang $\mathrm{H}$. Understanding customers repeat purchase intentions in B2C e-commerce: The roles of utilitarian value, hedonic value and perceived risk. Information Systems Journal. 2014;24:85-114. DOI: 10.1111/j.1365-2575.2012.00407.x 
[69] Choo J, Moon H, Kim H. Luxury customer value. Journal of Fashion

Marketing and Management: An International Journal. 2012;16:81-101

[70] Cheung MK, Zhu L, Kwong T, Chan WW, Limayem L. Online consumer behavior: A review agenda for future research. In: 16th Bled ecommerce Conference eTransformation; 9-11 June 2003; Bled: Slovenia 


\title{
A New Paradigm in Customer Relationship Management
}

\author{
Bhanu Prakash Nunna
}

\begin{abstract}
This chapter details around the new paradigm within Customer Relationship Management that the industry is going through. It covers topics like Customer Expectations, different levels in Customer Satisfaction, types of Customers especially talking about Millennial's and their mindset with respect to the expectations of a certain product, and how the customer relationship is changing the game in the market. This chapter also covers some of the key sections such as how Customer relationship management and information technology are playing a key role to enable firms to achieve their goals and targets. Finally, it summarizes some of the key successful best practices to be adopted by firms which can help build trust and relationship with their customers. There by increasing the revenue and customer satisfaction creating win-win situation for both parties.
\end{abstract}

Keywords: artificial intelligence, machine learning, CSAT, information technology, big data and CRM

\section{Introduction}

In this chapter, we will introduce some of fundamental approaches to start building customer relationship, go over the relationship between CRM and IT.

I believe that every user has some basic expectations in terms of customer relationship irrespective of whether a firm or an organization has a department to handle the same and if a firm is willing to invest in such positions who manage relationship with customers.

What is Customer Relationship Management? What are the key goals of CRM for any firms or organizations? How do we measure CRM metrics? What are the different logical levels of CRM? These are some of the basic questions that anyone would have. In my view, Customer Relationship Management is a journey and not a milestone. The reason it is journey is because the wants of the customer changes every day-in, day-out. So, firms need to constantly evolve and try to understand the actual requirements of customers, provide him/her with insight into your latest product/services portfolio and ensure he/she is happy with the suggested solutions. It again depends on the life cycle of product/services of the firms until what stage of the product life cycle they think that the relationship needs to be served.

Organizations have to define the goals and objectives which are measurable and traceable for all roles involved in Customer Relationship Management. This will help firms to measure and track the progress of the Organization in terms of how their products are performing and what customers are saying about their over-all experience when they consume the products/services of any organizations. 


\section{Customer relationship management and IT}

Customer Relationship Management as mentioned earlier is a journey and not a milestone. After the third industrial revolution, which marked a new era with Information technology as a new domain in the industrial sector, the fourth revolution totally changed the way people connect with each other, how IT is becoming one of the core platforms in every industry that we can think. People are smarter, think differently and their choices entered into a new level creating a different bench mark for firms to satisfy the customers.

Customer Relationship existed from early 80 s as well but it was very straight forward and targeted towards managing relationships on a regular basis using human interactions. For example, when I used to go to a bank during mid-80s, my father used to know lot of people in the bank including Bank Manager. Having said that, that generation used to maintain human relations with all the people with whom they meet on a daily/monthly basis. Even for that matter, the vegetable vendors, bankers, grocery store managers, people working in hospitals etc. This was the time when there was an implicit Customer relationship which is being maintained by every business/firms in a very interactive way.

After industrial revolution 3.0 [1], people's mindsets have changed, priorities are different, how people connect with each other is entirely different and the expectations of the customers reached to a different level as the customers are more knowledgeable, they have access to any information they want digitally and people have become much more smarter and advanced in their thinking. With industrial revolution 4.0 [2], firms/businesses need to think differently in order to meet the expectations of the current generation of population.

It is the generation where people look for solutions which can help achieve their wants and needs much faster than the earlier generation would expect. Here is where, IT plays a much bigger role to help achieve the target solution required to keep the customers happy. Businesses/Firms, either small or big need to really understand who their target customers are in order to serve them better. CRM solutions will help realize the firms targets if implemented in a rightful manner. It is not necessary that firms implement CRM solutions which are expensive but with Industrial revolution 4.0, there are multiple different ways where firms can come up with innovative solutions to understand customers wants/needs, help achieve them and also continue the journey along with the customer during the life cycle of the product including helping them leverage new upcoming features of the product. For the sake of discussion, imagine you are an owner of a Pizza shop. Now to improve your sales, you will need to understand some basic trends in what type of pizzas are being sold more during certain weather conditions or gaming season like NFL/Soccer or holiday season like Christmas, Thanks giving etc. This trending data can be leveraged to understand the demographic data of majority of customers and if there are any outliers, if so can we leverage those outliers etc. This trending data can be captured using modern CRM solutions and apply artificial intelligence on the historical data, so that we can come up with some patterns. Some of the Qualitative data analysis research methods like content or narrative analysis or grounded theory based on the use cases to be experimented. Not every business can afford to apply AI on their systems as they are more costly as of now (may be in future they become commoditized). In case of smaller firms, they can build smart solutions like Mobile Apps or request customer to fill a small survey (three to five questions max) or have feedback link on their site or request customer to answer couple of questions during payment of their order, which will help these firms to capture all the customer information they need. In some cases, quantitative research methods like Descriptive Statistical analysis using percentages, frequency could also 
be very helpful in simple analysis and applying AI models to generate consensus. In scenarios where we need supervised learning based AI models, we could leverage inferential analysis using Regression models to determine future predictions.

In-case of large firms, there are lot of ways to capture customer analytics data using big data solutions, which will help gather all the log information, trending info, recent order information and demographic information for the firms to do prediction AI modeling or un-supervised AI modeling. Firms can also adopt phase wise approach by implementing Chat-Bots which will capture initial customer data, then process that data to apply AI on top of it to predict what kind of car is suitable for a particular customer based on the input they provide in chat bots. Some of the revolutionary solutions that firms can think of are using Artificial Intelligence (AI), Chat-bots (Robotic process automations), Mobile apps to serve customer better and social networking web pages like face-book pages and twitter handles, etc.

\subsection{Types of customers}

In early 90s, when we go to buy a TV from an electronic store, the way the customer is treated is entirely different from the way customer is treated in current generation. Earlier, the wants of the customer where simple considering the TV whether it is color/black and white, whether the TV is of good brand and price plays a major role. Consider the same scenario in 2019, when we go to a digital store to buy a TV, customer is very knowledgeable in terms of his requirements such as size, clarity, colors, internet connectivity, no of ports it supports, no of apps it supports, etc. The wants of the customer has changed drastically but the way firms maintain the relationship with the customer I believe needs lot of change. The same salesman will showcase the different TVs and if asked he will provide details on the specifications and that's it. The reason I bring this example is to list down different types of Customers and how the CRM changes with these types.

I believe there are three types of Customers in general: (1) Legacy Customer, (2) Hybrid Customer, (3) Innovative Customer. Legacy Customers are those people who would love to stick to their age old value systems which they believe strongly. These customers, in spite of new products in the market, they would want to stick their value system and look for products/services which fit their need.

\subsection{Legacy customer}

Customers who are of generation before 1970s, these customers do not tend to change themselves along with the current generation. Their value system prefers human connect and relationships are stronger. For example, if a customer in this segment visits a showroom to buy a TV, his criteria to buy would be entirely different in the sense that it could be as simple as good clarity, bigger, cheaper and very user friendly. These properties are good enough to take a decision. For this segment of users, price plays a major role in decision making and also post sales servicing as well. These are very loyal customers and we cannot afford to lose them.

\subsection{Hybrid customer}

These type of customers fall in between 1970s and 1980s. The challenge with these types of customers is that they want to follow older generation in certain aspects and new generation in certain aspects. This is where it becomes challenging to serve these types of customers. Need to carefully handle these types of customers as these are loyal customers and ready to adopt new technologies as per the trend. Customers in this segment look for value for money, pricing and some adoption of 
new features. For firms, these customers can be targeted to improve the sales and there-by increasing the revenue. If businesses can maintain good trusted relationship with these customers, then they will become return and loyal customers and go a long association with the firms.

\subsection{Innovative customer}

The customers in this segment belong to Millennials. This generation users are very advanced, tech savvy and with high expectations in terms of any product they buy. Businesses/firms will have tough time understanding these users as their priorities change all the time, they needs and wants are dynamic in nature. For example, consider a scenario where a millennial visits a showroom to buy a Flat TV. Businesses have to think about innovative ways to develop trust and relationship with these customers. Millennials like quick responses, heavy feature load, discounts and one thing to be noticed is these customers do not compromise on the price as long as it is feature rich. It is easier to target these firms as long as we have a proper plan on the launch, provide technical details and provide deals. Think of Redmi, Amazon, or Flipkart deals on ecommerce sites where in the target is toward these millennials.

\section{Levels of CSAT}

\subsection{New paradigm in customer relationship management}

I believe that businesses/firms need to relook at the way they position customer for their products. They need to think about what kind of customer problems they are trying to solve and to which customer type instead of building product first and look for customers. This paradigm needs to change and keep customer relationship at its core which fuels the product engine. I understand that most of them already talked about this example of Apple's iPod, etc., but think of an example like Bose, which pioneered speaker systems. The main goal of the company is to provide extraordinary music experience with their products to customers. Irrespective of the price range, if firms are able to give the best experience for their products to the end customers, then sales will improve there by improving customer base. Similarly, customer relationship is a domain in itself. Every business need to have at least one representative who can think about, look into, address customer issues, and also manage customer relationship.

Earlier, businesses used to build products and then used to think about how to position themselves for products. I think the paradigm changed drastically and firms started thinking about customers first and then to solve their day to day problems or enable quick solutions to their mundane tasks, firms started coming up with product ideas. For example, we have started seeing a revolution in terms of the kind of mobile apps that are being built to solve customer problems. We have this app called Shuttl or http://ride.shuttl.com which is an App to help employees commute to their offices. The beauty of this app is it thinks about customer's pain points and enabled feature set. One recent example is that, I was traveling using this shuttle service and few folks stopped our bus. Suddenly, two folks from shuttl app got into our bus wearing their companies dresses, started handing over a small gift bag (which consisted of a Diary, nice pen and a pamphlet of offers). They told us that they are handing over this gift to mark their first anniversary of the company. This really blew my mind that how firms are evolving their customer relationship management by coming up with innovative 
ideas instead of going with traditional mode of surveys, feedback links, etc. I think all firms need to think something like this and come up with innovative ways to constantly have connection with their customer base. This will not only help firms evolve along with customer but also improve their sales and revenues accordingly. Some of the ideas which firms can implement are using events to touch base customers; it could be holiday season or New Year or company anniversary, etc.

\subsection{Role of IT in customer relationship}

The Customer information we capture during any product or service buying experience is very important. The reason is that is the fundamental way to know, understand and connect with the consumer of your product or service. IT plays a major role in making or breaking the trust and belief of customer which decides the future business of any product or service. With the IT revolution, there are lots of tools or applications which help capture customer information, analyze and come up with some inferences around whether a particular customer is new, existing, loyal and/or most valuable with respect to the products they consume.

The role of IT has become inherent with any domain. Meaning, during early 80 s it used to be that only certain functional areas used to leverage IT to capture, store and update data for example like Banks, Healthcare, etc. After nearly three decades, IT has become an integral part of every domain. For example, IT is used in automobile industry, finance, insurance, food industry, textile, pharmaceutical, oil and natural gas, etc. With IT revolution 4.0, information technology solutions with technologies like IoT, AI, Machine Learning, Big Data, etc., and information is leveraged to automate even certain home appliances like Refrigerators, Microwave Ovens (smart Ovens), Smart Houses, Smart Offices [3], etc.

Some of the other areas that IT is used include sports, for example, soccer players are hooked up with sensors to read information of a football player during the match [4] is being played to analyze his mental and physical ability to deal with the circumstances.

One thing I want to stress is that if we leverage customer information with right set of data models and mathematical models, then definitely we can leverage the reports to predict the customer behavior in terms of whether he will return to buy the same product or not. Firms have to leverage IT with proper machine learning models in order to predict if certain customers will help increase the revenue, if certain demographic users can be converted into new customers based on their behavioral analysis.

\section{Major pitfalls in CRM implementations}

CRM software if not leveraged the right way, then there is potential for negative impact on the firms rather than positive. Especially, in emerging markets, I personally have noticed so many instances where customer relationship is being misused or abused. For example, in developing nations, it is easier to capture customer information if you come up with some flyer which showcases some festive season sale or discounted prices for some of products, etc. Let us take a hypothetical example of Joe going to a mall and there is this guy showing a flyer which talks about massive discounts on some products in a branded store. With the flyer, is an attached form which users fill to get those discounts?

If you look at above scenario, usually people might feel there is no risk. But if you actually think about this information might land into some of the product companies which try to buy customer information from these firms. These firms 
sell this information which they received directly from customer. They might sell this information to companies like Target, Best Buy, Honda, Nike, etc as they know you basic PII data from this exercise. It has been a nightmare in emerging countries because firms keep buying this information from MNC companies and start calling people in order to sell their product or service. Out of nowhere, someone calls you and gives your identity and checks if you are interested in a fitness boot camp, or a plot or a flat.

Information if used at the right place, with right set of people and tools, with right analysis, it would be a powerful tool to increase your sales, revenue, customer satisfaction and most importantly your long term relationship with the customer. Some of the other pitfalls in CRM implementations is some firms keep contacting customers every other week or once a month, some firms do not connect with their new customers to understand their experience in order for them to buy same product next time which makes them a return customer. In few more cases, firms collect information of the customers during product buying experience and come up with some deals like customers will enter into a lucky draw to get a Free Washing Machine and customers will never get to know who is that Winner and his details.

Finally, what I would like to conclude is that CRM implementations need to be very well thought through. I believe that banks, insurance firms, healthcare service providers like diagnostic centers misuse this information at least in emerging markets by bugging customers or overloading the customers with SMS, phone calls, emails, etc. and because of this customer gets frustrated and starts to unsubscribe to these firms in order to reduce this spam or noise.

\section{Best practices to improve customer relationship management}

While we discussed about major pitfalls in CRM implementations, there are some really great experiences that I personally remember. The first example that I quote is of Fidelity Investments in USA. I love their CRM implementations for example, no matter where you are in the world, the way they greet people, understand customer problem and try to take utmost care to solve their issues.

Some of the best practices include:

- Understand Customer requirements thoroughly.

- Never try to fit your product features with customer requirements in-fact its other way around.

- Build your CRM eco-system in order to help customer with problem solving than converting customers to your brand.

- Always believe that there are enough customers if you come up with a product or service which solves the real problem than short term solutions.

- Never ever frustrate any customer by constantly calling them or by spam calls.

- Always value customer's valuable time and provide solutions accordingly.

- Firms need to mentor their CRM eco system to be great listeners

- Ensure your team in product customer care centers has best behavior and empathy toward customers than meeting their targets. 
Make sure the CRM tools [5] or applications you build for your products capture the right information to build new customer base, retain existing customers, address loyal customer problems and gives best customer experience through-out the life cycle of the product or service.

\section{Conclusions}

Finally, I hope this chapter at a high level gives an overview of CRM eco system, their users and different scenarios and how to build an eco-system which helps firms learn from customers, take feedback and make necessary changes to ensure customer satisfaction is achieved, also there by increases the user base for any product or service during its life cycle. I want to keep it simple and not make it complicated with mathematical models, etc., as I believe that there are some fundamental changes required before we even think about implementing mathematical models for AI based CRM implementations which will greatly enhance customer experience and satisfaction.

\section{Notes/Thanks/Other declarations}

I would like to thank all my professors of Indian Institute of Management, Kozhikode, India for encouraging me to contribute to international subscribers.

\section{Author details}

Bhanu Prakash Nunna

Wipro Technologies, Hyderabad, Telangana, India

*Address all correspondence to: b_prakash2000@yahoo.com

IntechOpen

(C) 2020 The Author(s). Licensee IntechOpen. This chapter is distributed under the terms of the Creative Commons Attribution License (http://creativecommons.org/licenses/ by/3.0), which permits unrestricted use, distribution, and reproduction in any medium, provided the original work is properly cited. (cc) BY 


\section{References}

[1] The economist web page.

Available from: https://www.

economist.com/leaders/2012/04/21/

the-third-industrial-revolution

[2] Forbes.com web page. Available from: https://www.forbes.com/sites/ bernardmarr/2018/09/02/what-isindustry-4-0-heres-a-super-easyexplanation-for-anyone/\#73aa2079788a

[3] Harvard published article. Available from: https://hbswk.hbs.edu/item/ walmart-s-workforce-of-the-future

[4] Web page on product for soccer players. Available from: https://www. playertek.com/us/playertek/

[5] Web page published listing CRM tools. Available from: https:// www.softwaretestinghelp.com/ best-crm-software-tools/ 



\section{Edited by Danil Dintsis}

All of us enjoy individually specific service or a product that is delivered for us only. Customer relationship management (CRM) is the area of expertise that helps companies to work with customers based on their specific needs or requirements. To reach success

CRM systems implement the most powerful math and IT tools such as statistical analysis, artificial neural nets, and graph systems. This book deals with the practical implementation and meta-analysis of CRM experience in various locations and business areas. The authors have produced a great book and provided meta-analysis of the latest CRM systems and a roadmap of their development. In the chapters, our readers will find descriptive analysis of CRM models, applied tools, and methods.

\section{IntechOpen}

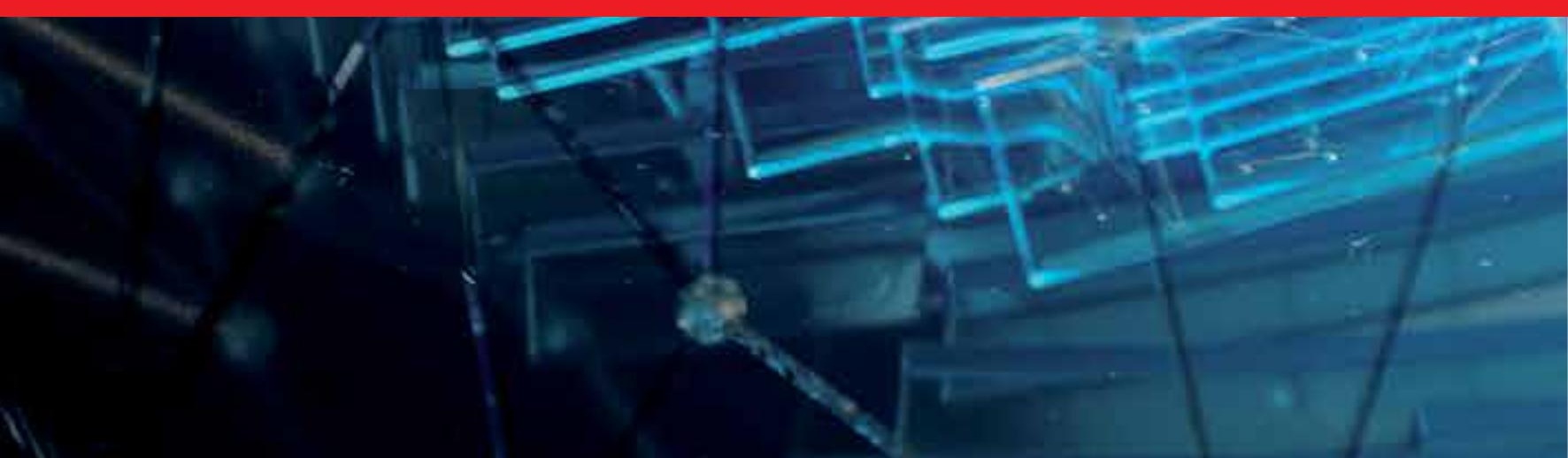

